NBSIR 82-2510

\title{
Quality of Inspections Utilizing Infrared Technology on Weatherization Retrofit Installations
}

U.S. DEPARTMENT OF COMMERCE

National Bureau of Standards

National Engineering Laboratory Center for Building Technology

Washington, DC 20234

November 1982

Prepared for:

Building Energy Sciences Branch

Building Systems Division

Office of Building Energy Research and Development U.S. Department of Energy

Washington, DC 20585 

1.1

QUALITY OF INSPECTIONS UTILIZING

INFRARED TECHNOLOGY ON

WEATHERIZATION RETROFIT

\section{INSTALLATIONS}

Yui-May L. Chang

Richard A. Grot

U.S. DEPARTMENT OF COMMERCE

National Bureau of Standards

National Engineering Laboratory

Center for Building Technology

Washington, DC 20234

November 1982

Prepared for:

Building Energy Sciences Branch

Building Systems Division

Office of Building Energy Research and Development

U.S. Department of Energy

Washington, DC 20585

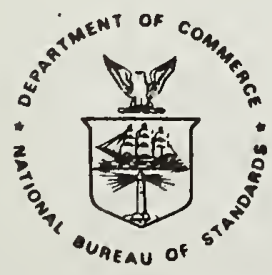

U.S. DEPARTMENT OF COMMERCE, Malcolm Baldrige, Secretary NATIONAL BUREAU OF STANDARDS, Ernest Ambler, Director 



\section{ABSTRACT}

A comparative evaluation of various portable infrared sensing systems used for detecting heat loss anomalies within building envelopes was performed. This is the second of a two-stage applied research program sponsored by the Department of Energy to assess the application and reliability of using infrared technology. Twelve single-family residences in three cities from the Weatherization Program of the Community Services Administration were employed as field samples. The results of infrared surveys carried out by thermographic surveying firms and those by the National Bureau of Standards were analyzed and compared in the categories of: completeness of scanning, identification of defects, weather condition of inspection, and method of equipment operation. The thermograms of uninsulated areas, sketches of observed thermal deficiencies, and total areas of defects for each dwelling are presented. Through the comparison, the degree of completeness of inspecting the residences thoroughly was evaluated to be the most important factor for defect identification. The results of thermographic inspection of the homes showed that serious thermal anomalies still existed in most of these 'weatherized' residences, with a majority exhibiting between 5 percent and 15 percent of the wall areas uninsulated, or defective. The total uninsulated areas observed by each surveyor was found to be affected by the quality of thermograms submitted.

Key Words: Building heat losses; comparison of inspections; infrared scanning systems; insulation voids; interpretation of thermograms; thermal deficiencies; thermographic inspections; weatherization retrofits 


\section{PREFACE}

This report is one of a series documenting National Bureau of Standards research and analysis efforts in support of the Department of Energy/Oak Ridge National Laboratory/National Bureau of Standards" Building Thermal Envelope Systems and Insulating Materials" Program. The work covered in this report was performed under the "Laboratory Tests in Support of Thermographic Standards" project and under DOE/NBS Interagency Agreement No. DE-AI05-780R06113, Task No. 11 . 


\section{ACKNOWLEDGMENT}

This report is based on the data and analysis submitted to NBS by the New England Innovation Group (NEIG) under contract 非B80SBCA0337. The authors wish to acknowledge the professional efforts of Dr. Richard Munis and Mr. Rick Regan of NEIG, without which this work would not have been possible. 
CONVERSION FACTORS TO METRIC (SI) UNITS

\begin{tabular}{lcccc}
\hline $\begin{array}{l}\text { Physical } \\
\text { Quantity }\end{array}$ & Symbol & $\begin{array}{c}\text { To Convert } \\
\text { From }\end{array}$ & To & Multiply By \\
\hline Length & $\mathrm{L}$ & $\mathrm{ft}$ & $\mathrm{m}$ & $3.05 \times 10^{-1}$ \\
$\begin{array}{l}\text { Area } \\
\text { Volume }\end{array}$ & $\mathrm{A}$ & $\mathrm{ft}{ }^{2}$ & $\mathrm{~m}^{2}$ & $9.29 \times 10^{-2}$ \\
Temperature & $\mathrm{T}$ & $\mathrm{ft}^{3}$ & $\mathrm{~m}^{3}$ & $2.83 \times 10^{-2}$ \\
Temp. Diff. & $\mathrm{dT}$ & Fahrenheit & Kelvin & $\mathrm{K}=(\mathrm{TF}) / 1.8$ \\
Wind Speed & $\mathrm{W}$ & $\mathrm{ft} / \mathrm{min}$ & $\mathrm{m} / \mathrm{s}$ & $5.08 \mathrm{x} 10^{-3}$ \\
\hline
\end{tabular}


ABSTRACT $\ldots \ldots \ldots \ldots \ldots \ldots \ldots \ldots \ldots \ldots \ldots \ldots \ldots \ldots \ldots \ldots \ldots \ldots \ldots \ldots \ldots \ldots \ldots \ldots \ldots \ldots \ldots$

PREFACE $\ldots \ldots \ldots \ldots \ldots \ldots \ldots \ldots \ldots \ldots \ldots \ldots \ldots \ldots \ldots \ldots \ldots \ldots \ldots \ldots \ldots \ldots \ldots \ldots \ldots \ldots \ldots \ldots \ldots$

ACKNOWLEDGMENT $\ldots \ldots \ldots \ldots \ldots \ldots \ldots \ldots \ldots \ldots \ldots \ldots \ldots \ldots \ldots \ldots \ldots \ldots \ldots \ldots \ldots \ldots \ldots \ldots \ldots \ldots$

SI CONVERSION

LIST OF TABLES

LIST OF FIGURES

vi11

1. INTRODUCTION $\ldots \ldots \ldots \ldots \ldots \ldots \ldots \ldots \ldots \ldots \ldots \ldots \ldots \ldots \ldots \ldots \ldots \ldots \ldots \ldots \ldots \ldots \ldots \ldots \ldots$

2. THERMOGRAPHIC INSPECTION AND INTERPRETATION FROM

THERMOGRAMS SUBMITTED BY CONTRACTORS

3. DATA ANALYSIS AND SUMMARY

4. CONCLUSION

5. REFERENCES

APPENDIX

I. Fargo House 非

II. Fargo House 非

III.

Fargo House \#3

IV.

Fargo House 非

V.

Minneapolis-st.

............

A-21

VI.

Minneapolis-St. Paul House \#

A-27

VII. Minneapolis-St. Paul House \# 
Table 1. Comparison of Insulation Voids Given in $\mathrm{ft}^{2}$ observed by Each Survey Firm and NBS ......................

Table 2 .

Thermal Defects Observed in Each Dwelling

Table Ia.

Summary of Defects Observed in Fargo House \#1

$\mathrm{A}-2$

Table Ib. Environmental Conditions Recorded at Inspections of

Fargo House 非 1

$A-4$

Table IIa. Summary of Defects Observed in Fargo House \#2

$A-7$

Table IIb. Environmental Conditions Recorded at Inspections of

Table IIIa. Summary of Defects Observed in Fargo House \#3

Table IIIb.

Environmental Conditions Recorded at Inspections of

Fargo House 非

Table IVa.

Summary of Defects Observed in Fargo House \#4

Table IVb.

Environmental Conditions Reported at Inspections of

Fargo House 非 4

Table Va.

Summary of Defects Observed in Minneapolis-

St. Paul House 非 1 .

Table Vb.

Environmental Conditions Reported at Inspections of

Minneapolis-St. Pau 1 House \#1

Table VIa.

Summary of Defects Observed in Minneapolis-

St. Paul House 非

Table VIb.

Environmental Conditions Reported at Inspections of

Minneapolis-St. Paul House \#2

Table VIIa.

Summary of Defects Observed in Minneapolis-

St. Paul House 非 3

Table VIIb.

Environmental Conditions Reported by Inspections of

Minneapolis-St. Paul House \#3

Table ViIIa. Summary of Defects Observed in Minneapolis-

St. Paul House $\$$ 非 
Table VIIIb. Environmental Conditions Reported by Inspections of Minneapolis-st. Paul House $\#^{4}$...................... A 444

Table IXa. Summary of Defects Observed in Portland House \#1 ......... A-47

Table IXb. Environmental Conditions Reported at Inspections of Portland House $\|_{1}$............................... A-50

Table Xa. Summary of Defects Observed in Portland House \#2 ........ A-54

Table Xb. Environmental Conditions Reported at Inspections of Portland House $\$ 2$................................ A-56

Table XIa. Summary of Defects Observed in Portland House \#3 .......... A-59

Table XIb. Environmental Conditions Reported at Inspections of Portland House $\$ 3$................................ A -61

Table XIIa. Summary of Defects Observed in Portland House \#4 ......... A-66

Table XIIb. Environmental Conditions Reported at Inspections of

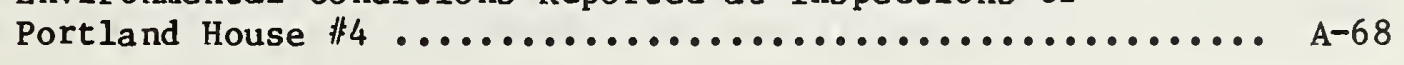


Figure 1. Distribution of Defective Areas in Dwellings

Ins pected ....................................

Page

Figure I. Thermal Deficiencies Observed in Fargo House $\#_{1} 1 \ldots \ldots \ldots \ldots$ A-71

Figure II. Thermal Deficiencies Observed in Fargo House \#2 ....... A-72

Figure III. Thermal Deficiencies Observed in Fargo House $\equiv^{3} 3 \ldots \ldots \ldots \ldots$ A-73

Figure IV. Thermal Deficiencies Observed in Fargo House \#4 ........ A-74

Figure Va. Thermal Deficiencies Observed on the First Floor in Minneapolis-St. Paul House \#1 ................... A-75

Figure Vb. Thermal Deficiencies Observed on the Second Floor in Minneapolis-St. Paul House $\# 1 \ldots \ldots \ldots \ldots \ldots \ldots \ldots \ldots \ldots \ldots$ A-76

Figure VIa. Thermal Deficiencies observed on the First Floor in Minneapolis-St. Paul House \#2 .................. A-77

Figure VIb. Thermal Deficiencies Observed on the Second Floor in Minneapolis-St. Paul House $\$ 2$................... A-78

Figure VIIa Thermal Deficiencies Observed on the First Floor in Minneapolis-St. Paul House \#3 ..................... A-79

Figure VIIb. Thermal Deficiencies Observed on the Second Floor in Minneapolis-St. Paul House \#3 ................... A $\mathbf{A} 80$

Figure VIIIa. Thermal Deficiencies Observed on the First Floor

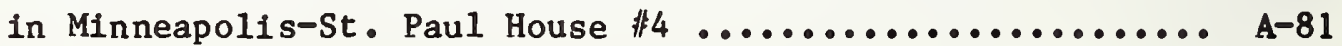

Figure VIIIb. Thermal Deficiencies Observed on the Second Floor in Minneapolis-St. Paul House $\$ 4$.................... A-82

Figure IXa. Thermal Deficiencies Observed on the First Floor

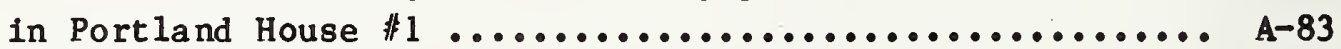

Figure IXb. Thermal Deficiencies Observed on the Second Floor

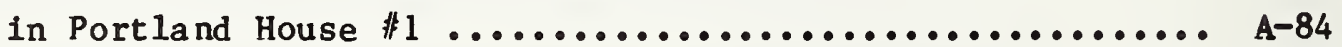

Figure Xa. Thermal Deficiencies Observed on the First Floor in Portland House $\left.\right|_{2}$

Figure $\mathrm{Xb}$. Thermal Deficiencies Observed on the Second Floor in Portland House \#2 


\section{LIST OF FIGURES (Continued)}

Page

Figure XI. Thermal Deficiencies Observed in Portland House \#3 ...... A-86

Figure XIIa. Thermal Deficiencies observed on the First Floor

in Portland House $\|^{4} \ldots \ldots \ldots \ldots \ldots \ldots \ldots \ldots \ldots \ldots \ldots \ldots \ldots$ A $-8 . \ldots$

Figure XIIb. Thermal Deficiencies Observed on the Second Floor

in Portland House $\$ 4$

A-88 

The infrared radiation measurement to assess the energy loss in building structures has been shown as a viable technique for noncontact measurements of surface temperature distribution [1,2]. Based on the fact that insulation materials impede the flow of thermal energy, infrared thermography can be utilized to provide images of the temperature distribution along the surface of a building envelope and interpret the thermal defects of building envelopes. The thermal defect problems include missing insulation, voids or cracks within the insulation itself, improperly installed insulation, wet insulation, air leakage, air penetration, etc. Prior to the weatherization of buildings, this technique is capable of locating the regions having high heat loss in order to appraise more adequately the retrofit requirements of the building. Thermographic inspection can also be employed as a quality control tool to evaluate postweatherization retrofits $[3,4]$.

Essentially, a thermographic survey is a tool to detect thermal abnormalities and to determine insulation effectiveness in buildings. In spite of the fact that the thermographic inspection involves only measurement of relative apparent surface temperature distribution instead of the profiles of surface heat flux, the thermal patterns produced are able to identify thermal anomalies within building envelopes. Thermography is an indispensable technique to locate and document heat loss anomalies in buildings that are not evident to the human eye. Further development of this technique will result in improved diagnostic procedures for determining building performance as well as building envelope energy efficiency.

The infrared equipment currently available and being used for energy surveys can be classified as:

(1) high resolution thermal image systems (HRIS);

(2) low resolution thermal image systems (LRIS);

(3) thermal line scanners; and

(4) spot radiometers.

In order to assess the potential of each of the foregoing classes of infrared equipment for locating defects in buildings, an attempt was made to conduct a comparative evaluation of portable infrared sensing devices for detecting heat loss in buildings. Accordingly, a two-stage program was developed to invite participants using the most common thermographic equipment employed in building inspections, to locate thermally defective areas in buildings.

Stage one consisted of a laboratory test undertaken by thermographic firms in a "cold room" at the U.S. Army Cold Regions Research and Engineering Laboratory (USACRREL) [5]. The conclusions of the laboratory tests indicate that when various classes of infrared scanning equipment were compared, the high resolution systems performed better than the low resolution systems and the line scanners. Furthermore, all systems did better in detecting defects than in determining regions of insulation levels, and the low resolution image system did not perform well at the lowest indoor/outdoor temperature differential. 
Stage two involved a field evaluation of infrared inspection contractors, using residences inspected by NBS as part of the Community Services Administration (CSA) Weatherization Program [6] as a baseline. Simultaneously, cost effectiveness and quality of inspection services offered by thermographic firms could also be assessed. In order to confirm the validity of both laboratory and field tests, the same types of infrared devices were used to perform the scanning for both measurements. The field test of this project was coordinated by the New England Innovation Group, which also provided the interpretation of the data submitted by the thermographic inspection contractors. There were two phases of evaluation in the field tests. According to the types of data recorded by NBS during thermographic inspections, the dwellings used for field evaluation were divided into two groups. Phase one of the field evaluation consisted of those homes where thermograms were produced by NBS during inspection. Phase two would be those homes where videotapes were recorded by NBS during scanning. This report includes the comparison and analysis of thermograms for phase one of the field evaluation.

In phase one, the field evaluation was carried out in four cities: Portland, Maine; Fargo, North Dakota; Minneapolis-St. Paul, Minnesota; and St. Louis, Missouri. In these cities single-family, cavity frame wall, low-income housing had been retrofitted by the CSA with various types of wall insulation. Eight thermographic inspection firms were asked to inspect different dwellings in these four cities. The types of infrared sensing devices which were utilized included five high resolution thermal image systems (resolution less than $0.5^{\circ} \mathrm{F}$ ), a low resolution thermal image system (resolution greater than $0.5^{\circ} \mathrm{F}$ ), a thermal line scanner used in conjunction with a spot radiometer, and a pyroeletric vidicon. In the baseline inspection, NBS used a high resolution image system to scan each dwelling thoroughly for quality control of the weatherization retrofits. Using NBS infrared survey results as a baseline, comparisons were performed on the results of thermograms, photographs, and contractors' own interpretations of the data obtained by thermographic inspection contractors. 


\section{THERMOGRAPHIC INSPECTIONS AND INTERPRETATION FROM THERMOGRAMS SUBMITTED BY}

CONTRACTORS

of the eight firms which participated in the comparative evaluation of thermographic inspections, the results of only six are analyzed and presented in this report. The data from the other two could not be compared with data from NBS and the other firms. One contractor using a spot radiometer submitted only general letter reports to describe the results of his inspection. Without documentation of any regions of voids, it was impossible to make direct comparison of void sizes with data from NBS and others. Documentation from another contractor, using a pyroelectric vidicon, only included a few locations having voids and air leakage paths and was not adequate for comparisons with data from NBS, as we11 as other contractors.

Due to the unfavorable weather conditions, contractors were unable to carry out inspections for residences in St. Louis. Hence analysis and comparison of inspections were performed for dwellings in only three cities - Fargo, Minneapolis-St. Paul, and Portland, with four residences in each city.

Since the void areas were estimated from documentation provided by each contractor, numerical data depend mainly on the quality of thermograms, area covered, interior furnishings which obstruct subject surface, and interpretation by contractors. The accuracy for estimating the size of void area was limited by random variables such as angles of viewing, equipment adjustments like sensitivity, and type of thermal anomaly.

The instructions given to each infrared inspection firm were to inspect the interior as well as exterior of each surveyed dwelling. They were also asked to submit reports documenting the location of all insulation voids, air infiltration paths, and other important building heat loss anomalies such as cracks, weatherstripping and caulking defects. However, only insulation voids in exterior walls were included in the comparative evaluation. Other sources of heat loss anomalies were only documented as recognitions.

In this report, thermographic inspection firms will be identified as contractors no. 1 through no. 6. Only contractor no. 1 was using a low resolution infrared system (LRIS) for scanning; the other five all used high resolution infrared systems (HRIS). Infrared contractor no. 1 covered the most dwellings in this program, four houses in Fargo and three houses in Minneapolis-St.Paul, for a total of seven houses. Although no thermograms were submitted, (the low resolution imaging system was not capable of producing hard copies of its display) sketches of walls with void areas in each room of every house furnished by contractor no. 1 provided a fairly complete documentation of the house condition. There was some difficulty by contractor no. 1 in using the low resolution scanning system to distinguish the differences in insulation performance levels in two houses located in Fargo and one house in Minneapolis-St. Paul. As a result, contractor no. 1 reported some partial void areas as "cool" areas instead, and the estimated void areas were substantially lower than results from NBS. Infrared contractor no. 2 surveyed six houses, four in Fargo and two in Minneapolis-St. Paul. Besides the interior photographs and thermograms of identical locations, no. 2 always included exterior photographs and orientation 
of the house. Such documentation was very effective for analysis of the thermographic data. However, contractor no. 2 did not cover the whole envelope during the inspection of two of its houses (one in Fargo and one in MinneapolisSt. Paul) and thus gave a much lower estimation of the void area than NBS' data.

Contractors no. 3 through no. 6 inspected four houses in one city, which overlapped the work of the other contractors. In other words, there were at least two contractors carrying out inspections for each dwelling. In spite of the fact that both contractors no. 3 and no. 4 submitted photographs and thermograms of identical locations of the respective homes in their inspection, they missed significant uninsulated areas in their observations, with the exception of Minneapolis-St. Paul house 非, where 27 thermograms were produced by contractor no. 4. Other dwellings in Minneapolis-St. Paul had 4, 9 and 13 thermograms from contractor no. 4 and dwellings in Fargo had between 7 to 10 thermograms from contractor no. 3. With such a small number of thermograms available, the actual void area of each mentioned home cannot be interpreted accurately from these incomplete inspections. Furthermore, it seemed that the sensitivity of the scanning systems used for these two contractors (no. 3 and no. 4) was set incorrectly, thereby providing insufficient resolution for void detection. Hence the estimated void areas provided by these contractors were lower than those for the NBS survey.

Four houses in Portland were inspected thoroughly by contractors no. 5 and no. 6. Contractor no. 5 submitted the most elaborate documentation of envelope heat loss anomalies, with sketches provided for each house giving locations where the thermograms and observations were taken, stating the dimensions of voids, and giving the probable causes of the heat loss anomalies. Contractor no. 6 described in detail the weather conditions, interior temperature conditions, and other factors that might present a problem in interpreting the data from the scanning. Even though some thermograms taken by contractors no. 5 and no. 6 were not focused correctly, estimations of void area from their results were close to NBS' data, with exceptions of Portland house \#2 from contractors no. 5 and no. 6, and Portland house 非 4 from contractor no. 5. The discrepancies in void estimation from these two cases were simply due to the failure to inspect the whole house by these contractors. Furthermore, none of the contractors seemed to include exterior thermographic scannings for any of these dwellings, as only interior thermograms were provided.

A detailed discussion of the analysis made, and comparisons of each dwelling's thermal defects are summarized in the following section. 


\section{DATA ANALYSIS AND SUMMARY}

A detailed analysis for each dwelling surveyed by contractors and NBS personnel is presented separately in the appendix. General descriptions of these residences, insulation options, sketches of thermal deficiencies, some thermograms as examples to demonstrate the location of heat loss anomalies, and comparative evaluations are also included in the appendix. A typical thermogram of a surface will provide an intensity-modulated image where the light and dark portion respectively represent the hot and cold region, and the grey shades indicate temperatures between hot and cold.

According to the analysis of results from infrared inspections, a summary of void areas estimated from thermograms and documents submitted by each contractor is presented in table 1. The total area of known defects of each dwelling in table 1 is based on results from all inspections. Using the sum of known defects of each house inspected by individual survey contractor as the total area of voids to be detected, the percentage of overall void areas identified by each surveyor is calculated and presented in table 1.

NBS personnel employed the draft American Standard Test Method (ASTM) for infrared inspection and achieved the highest percentage, 93.5, of defective area observed. Furthermore, the defective regions in Fargo house \#1 not recognized by NBS were due to camera malfunction and the result for Portland house 非 3 was provided by local staff of CSA. If the areas of these two houses were excluded, NBS would have 97.7 percent in defect detection.

Despite the difficulties with the use of LRIS at low temperature differentials, contractor no. 1 inspected and sketched every wall of each room in each house to indicate the locations and areas of defects. Hence it still recognized more than 70 percent of the existing voids. As for those using HRIS, contractors no. 2, no. 5, and no. 6 observed about 70 to 90 percent of existing voids. However, contractors no. 3, and no. 4 who could only find less than 50 percent of the total defects, in the authors' opinions, are considered to be questionable in terms of surveying performance.

A summary of thermal deficiencies interpreted from the thermograhic surveys for dwellings in these three cities is shown in table 2. As indicated in table 2, the most common heat loss locations observed in these dwellings are leakage paths around and through windows and doors; penetration from ceilings and walls; and infiltration paths at wall-to-wall joints. Furthermore, only one basement of a house was inspected in the survey and it was found to have heat loss in the regions above ground. It is also shown in the table that between 5 percent and 15 percent of the wall area defects have still remained in most of the dwellings after retrofit. Six of the dwellings surveyed had thermal defective areas accounted for 5 to 10 percent of total wall areas and three showed between 10 percent and 15 percent defective areas. Figure 1 illustrates the distribution of insulation voids among these houses. The average defective area of all dwellings is found to be 9.75 percent. 
Table 1. Comparison of Insulation Voids Given in $\mathrm{ft}^{2}$

Observed by Each Survey Contractor and NBS

City House NBS Survey Contractor Total Area of - No. No.1 No.2 No.3 No.4 No.5 No.6 Rnown-Defects*

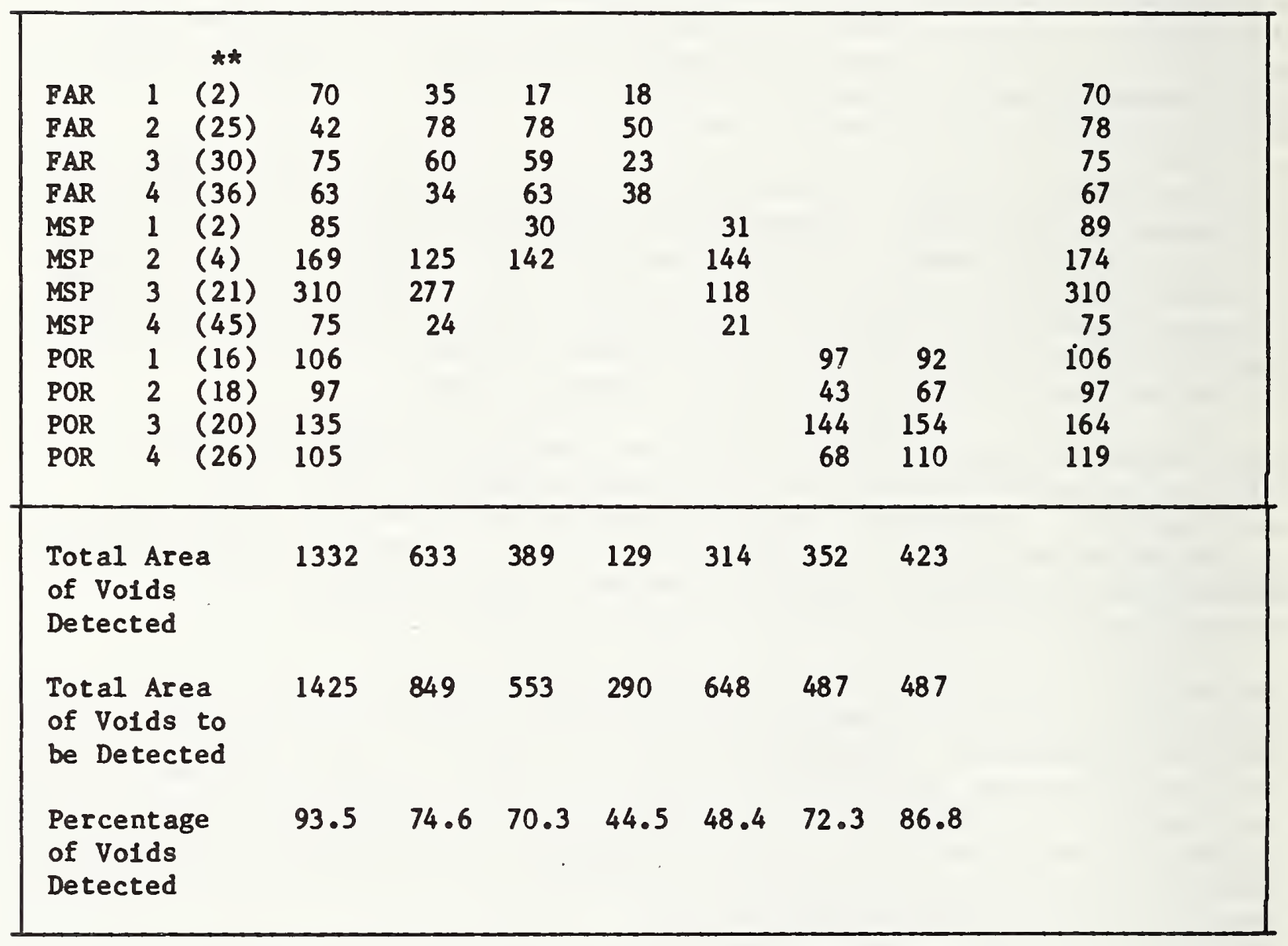

* Based on results of all surveys.

** Numbers in parenthesis denote corresponding house numbers in CSA program. 
Table 2. Thermal Defects Observed in Each Dwelling

City

FAR FAR FAR FAR MSP MSP MSP MSP POR POR POR POR

House No.

$\begin{array}{llllllllllll}1 & 2 & 3 & 4 & 1 & 2 & 3 & 4 & 1 & 2 & 3 & 4\end{array}$

\begin{tabular}{|c|c|c|c|c|c|c|c|c|c|c|c|c|}
\hline $\begin{array}{l}\text { Defective } \\
\text { Wa11 Area }\left(\mathrm{ft}^{2}\right)\end{array}$ & 70 & 78 & 75 & 67 & 89 & 174 & 310 & 75 & 106 & 97 & 164 & 119 \\
\hline $\begin{array}{l}\% \text { of Defective } \\
\text { Wa11 Area }\end{array}$ & $7 \%$ & $9 \%$ & $10 \%$ & $11 \%$ & $6 \%$ & $10 \%$ & $20 \%$ & $4 \%$ & $8 \%$ & $5 \%$ & $20 \%$ & $7 \%$ \\
\hline $\begin{array}{l}\text { Defects } \\
\text { Observed: }\end{array}$ & & & & & & & & & & & & \\
\hline $\begin{array}{l}\text { Walls } \\
\text { Shrinkage or } \\
\text { Fissures }\end{array}$ & & & & * & * & * & & * & & & & \\
\hline $\begin{array}{l}\text { Air } \\
\quad \text { Penetration }\end{array}$ & & & * & * & * & & * & * & * & & * & * \\
\hline Cellings & $\star$ & & & & & * & & & * & $*$ & & \\
\hline Flat & * & * & * & * & & $*$ & * & & * & * & * & * \\
\hline $\begin{array}{l}\text { Doors } \\
\text { Frames }\end{array}$ & * & * & * & * & & $\star$ & $\star$ & & * & & * & \\
\hline Alr Leakage & * & * & * & * & * & * & * & & * & & * & * \\
\hline Windows & & & & & & & & & & & & \\
\hline Frames & * & * & * & * & & & * & * & & * & * & \\
\hline Alr Leakage & * & * & * & * & * & * & * & & * & & * & * \\
\hline $\begin{array}{l}\text { Joints } \\
\text { Wa11-Wa11 }\end{array}$ & * & & * & * & * & * & & * & & & * & * \\
\hline $\begin{array}{l}\text { Celling-Wa11 } \\
\text { F1oor-Wal1 }\end{array}$ & * & * & * & * & * & * & * & & * & * & & * \\
\hline Eaves & * & & - & * & * & & & * & & & * & * \\
\hline $\begin{array}{l}\text { Basement or } \\
\text { Crawl Space }\end{array}$ & & & * & & & & & & & & & \\
\hline
\end{tabular}




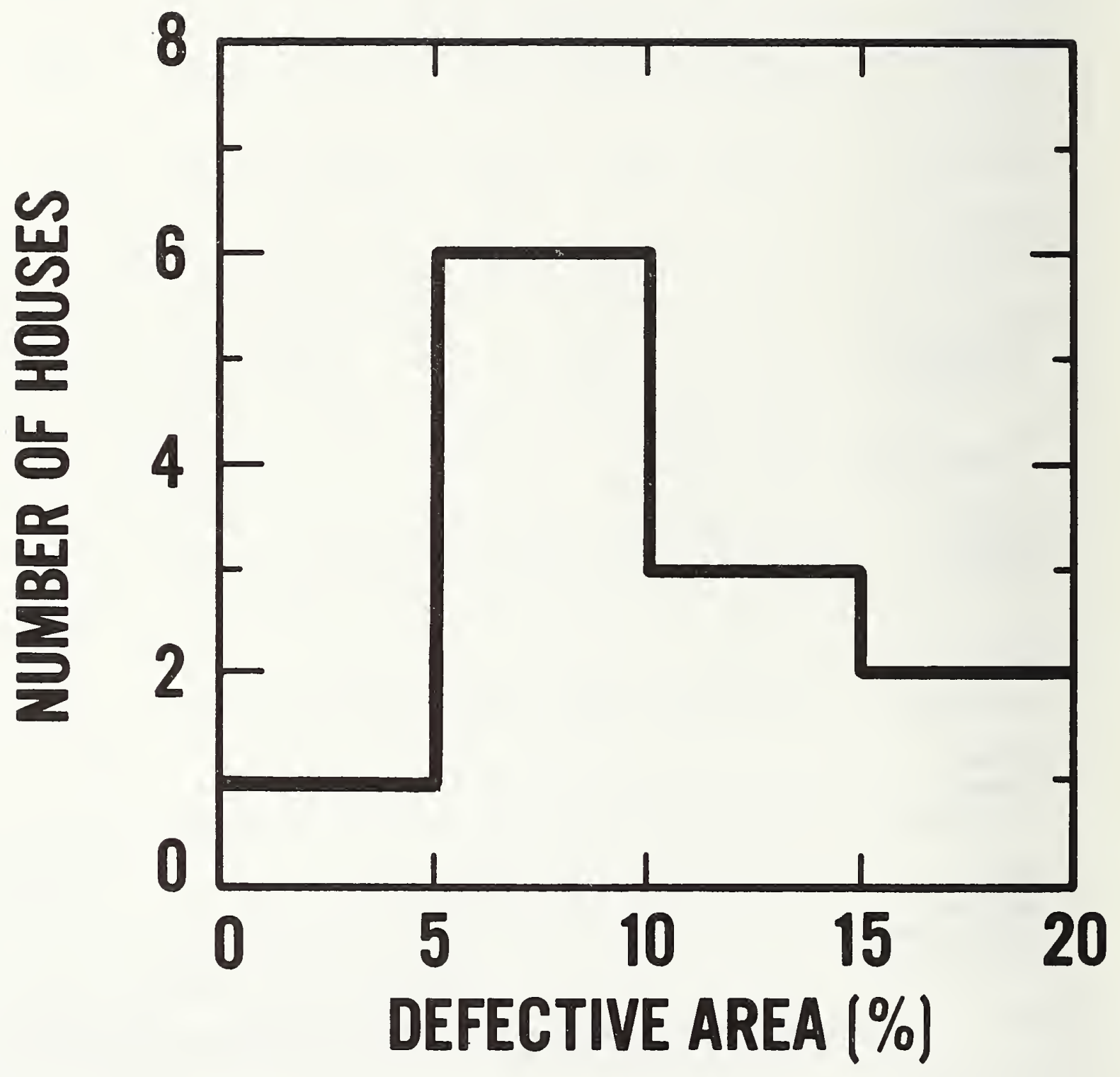

Number of houses $=12$

Mean area $=9.75 \%$

Figure 1. Distribution of Defective Areas in Houses Inspected 


\section{CONCLUSION}

The field inspection results showed that the infrared survey contractors located approximately 45 percent to 86 percent of the known thermal defects during their inspections. The main cause of fallure to locate defects is that contractors failed in many cases to inspect all exterior walls of each house involved. Thus the inspection procedures used by the infrared contractors are very important to the outcome of inpsections. The results of the interpretation of the thermographic data are affected by the quality of thermograms. With a higher operational cost, thermograms generated from contractors using HRIS are supposed to provide better documentations than sketches produced manually by the contractors using LRIS. However, many thermograms submitted by the contractors were quite poor in quality due to out of focus or lack of adequate thermal contrast. This causes uncertainty in the analysis and estimation of voids, and therefore causes a wide discrepancy in results among the contractors. There is a need to develop recommended measurement techniques, inspection procedures, and analysis methods to provide consistent results for infrared survey of buildings.

As for the quality of the installation of insulation into these dwellings, the results from this program indicated serious defects still existed in most of the houses after weatherization. Some defects, such as air penetration into ceilings, heat loss at soffits and eaves, and excessive heat loss from attics, are usually not considered as normal weatherization measures. However, defects such as missing insulation, shrinkage or fissures, air leakage at windows and doors, etc., are primarily due to a poor quality of workmanship. 


\section{REFERENCES}

1. Pettersson, B., and B. Axen, "Thermography-Testing of the Thermal Insulation and Airtightness of Buildings," Swedish Council for Building Research, Stockholm, Sweden, 1980.

2. Grot, R. A., D. T. Harrje, and L. C. Johnston, "Application of Thermograhpy for Evaluating Effectiveness of Retrofit Measures," Proceedings of Infrared Information Exchange 76, AGA Corp., Secaucus, New Jersey, 1978.

3. Mill, P. A. D., "Thermography-A New Tool for Diagnosing Building Performance and Quality Assurance," Proceedings of Thermosense II, Second National Conference on Thermal Infrared Sensing Technology for Energy Conservation Programs, American Society of Photogrametry, pp. 109-144, Falls Church, Virginia, 1980.

4. Grot, R. A., "The Interpretation of Thermographic Data for the Identification of Building Heat Loss." Proceedings of the Society of Photo-Optical Instrumentation Engineers, Vol. 254, Bellingham, Washington, 98227.

5. Grot, R. A., and R. H. Munis, "A Comparative Testing of the Applicability of Various Thermal Scanning Systems for Detecting Heat Losses in Buildings," Proceedings of Fourth Biennial Infrared Informatiom Exchange, p. 71-99, AGA Corp., Secaucus, New Jersey, 1979.

6. Crenshaw, R., R. Clark, R. Chapman, R. Grot, and M. Godette, "CSA Weatherization Demonstration Project Plan," NBSIR 79-1706, March, 1979. 
APPENDIX

\section{ANALYSIS AND COMPARISON OF THERMOGRAPHICAL INSPECTIONS}

\section{Fargo House 非 1}

This is a one-story, approximately 25 year old residence whose interior dimensions are $24 \mathrm{ft}$. in length, $25 \mathrm{ft}$. in width, and $7.4 \mathrm{ft}$. In wall height; located in Fargo, ND. There are 5 rooms of living space, with an attic and a basement. Its exterior construction contains metal siding and an asphalt shingle roof.

Prior to the weatherization program, this residence was insulated with $31 / 2$ " glass fiber batt insulation in the cavity walls. An insulation contractor was instructed to add UF foam to this existing insulation. After the retrofitted foam was injected into the walls, this dwelling was inspected by NBS personnel and IR contractors $\# 1$, 非, and 非. A sketch of the voids and the locations of heat loss obtained from thermograms and documents by NBS, as well as those by the IR contractors, is shown in figure Ia.

In general, the most common area of heat loss in this house were found at wal1celling joints, at corners (bridges), and also around the diagonal braces. This might be due to the defective sealing at eave junctions such that air leaked into the dwelling. Also, cold cellings were found at the corners of the south and north sides on the main floor as well as in the attic.

Thermographic inspection by NBS observed most known defects of this residence so that its result can be used as a baseline for comparison. Due to the fact that UF foam was added on to the existing insulation, different performance levels of insulation could be observed in locations where the foam did not reach the intended locations.

Contractor 非 1 , who used LRIS for inspection, had difficulties in identifying the partial insulation voids from different performance levels and sketched most of the locations of low temperatures as 'cool' areas instead of voids. This report will interpret these 'cool' areas as vold areas.

Contractors $\left.\right|_{2}$ and $\# 3$ failed to inspect several regions in this house as compared with the inspection by NBS.

A detalled description of the defects observed by NBS as wel1 as those by the IR contractors, is summarized in table Ia. Besides the total defective wall area in $\mathrm{ft}^{2}$ found by each inspection, table Ia also includes each defective wall area in $\mathrm{ft}^{2}$ of each room of the house, analyzed from avallable the rmograms and sketches. The total estimates of void areas is approximately $70 \mathrm{ft}^{2}$, which represents about 7 percent of the gross wall area. Table Ib presents the environmental conditions documented from each inspection. Thermograms/sketches 1-1 to 1-9 are some examples which demonstrate the locations of heat loss anomalies, as they are referred to in the descriptions in table Ia. 
Table Ia. Summary of Defects Observed In Fargo House \#1

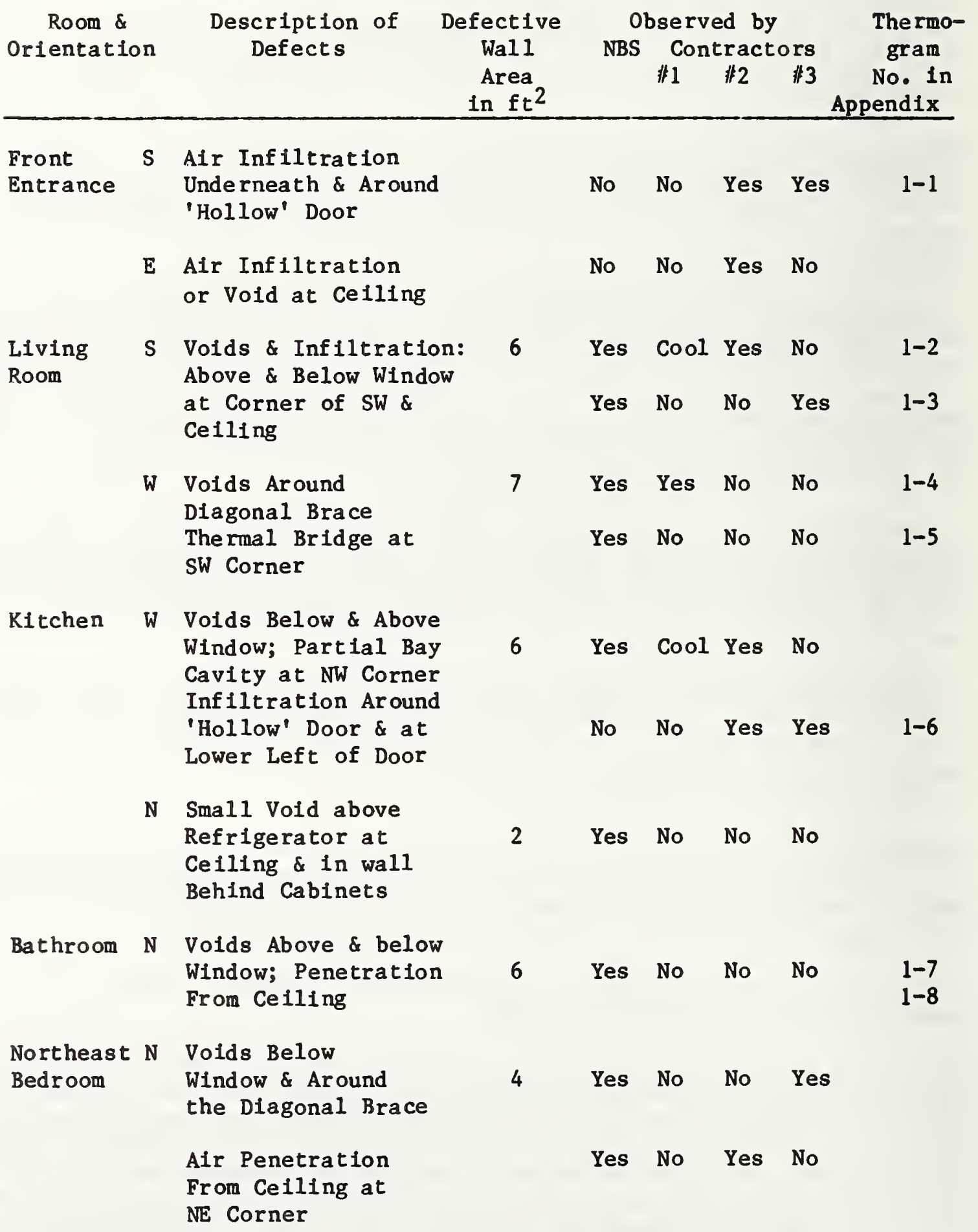


Table Ia. Summary of Defects Observed in Fargo House \#1

\begin{tabular}{|c|c|c|c|c|c|c|}
\hline \multirow{3}{*}{$\begin{array}{c}\text { Room \& } \\
\text { Orientation }\end{array}$} & \multirow{3}{*}{$\begin{array}{c}\text { Description of } \\
\text { Defects }\end{array}$} & Defective & \multicolumn{3}{|c|}{ Observed by } & Thermo- \\
\hline & & & NBS & Contra & ors & gram \\
\hline & & $\begin{array}{c}\text { Area } \\
\text { in } \mathrm{ft}^{2}\end{array}$ & & 非2 & 非3 & $\begin{array}{l}\text { No. in } \\
\text { Appendix }\end{array}$ \\
\hline
\end{tabular}

E 1 Half Bay Cavity at NE Corner

Partial Voids in

2 Upper Bays and Below Window with Infiltration

Southeast E Voids Above and Bedroom on Both Sides of Windows

1 Bay Cavity Above Diagonal Brace at $S$ of Window

Air Leakage at SE Corner

$S$ Voids Below Window Partial Void at SE Corner

2 Upper Bay Cavities at $W$ of Window

Air Penetration From Ceiling

Attic

$$
\begin{aligned}
& \text { E Voids Below Window } \\
& \text { Partial Bay Cavity } \\
& \text { at NE Corner }
\end{aligned}
$$

S Uninsulated Sloped Ceiling

W Voids Above \& at S Side of Window Uninsula ted S1oped Ceiling

N Uninsulated Sloped Ceiling

Total Wall Area of 7

Yes Cool Yes No

Yes No No No

12 Yes Yes No No

Yes Yes No No

1-9

Yes No Yes Yes

$1-10$

8 Yes No No Yes

Yes No No No

Yes Yes Yes Yes

4 Yes No Yes No

Yes No No Yes

Yes No No Yes

8 Yes No No No

Yes No No Yes

$1-11$

Insulation Voids Detected

$\begin{array}{lllll}70 & 70 & 35 & 17 & 18\end{array}$

Given in $\mathrm{ft}^{2}$ 
Table Ib. Environmental Conditions During Inspections of Fargo House \#1

\begin{tabular}{|c|c|c|c|c|}
\hline & NBS & Cont & $\begin{array}{l}\text { ractors } \\
\quad \# 2\end{array}$ & $\$ 3$ \\
\hline $\begin{array}{l}\text { Date } \\
\text { TIme }\end{array}$ & $\begin{array}{c}3 / 1 / 79 \\
11: 00 \text { am }\end{array}$ & $\begin{array}{c}4 / 10 / 79 \\
9: 00-10: 00 \mathrm{pm}\end{array}$ & $4 / 25 / 79$ & $\begin{array}{l}4 / 17 / 79 \\
10: 00 \mathrm{am}\end{array}$ \\
\hline Weather Condition & & & overcast & $\begin{array}{l}\text { bright } \\
\text { sunlight }\end{array}$ \\
\hline Outside Temperature & $10^{\circ} \mathrm{F}$ & & $47^{\circ} \mathrm{F}$ & $49^{\circ} \mathrm{F}$ \\
\hline Inside Temperature & $68^{\circ} \mathrm{F}$ & $\begin{array}{c}55^{\circ} \mathrm{F} \\
60^{\circ} \mathrm{F}(\mathrm{att} I \mathrm{c})\end{array}$ & $68^{\circ} \mathrm{F}$ & $67^{\circ} \mathrm{F}$ \\
\hline Inside Humidity & & & & $54 \%$ \\
\hline Wind Speed (MPH) & $5-10$ & & $2-5$ & $25-30$ \\
\hline Wind Direction & NW & & NW & SE \\
\hline
\end{tabular}


Thermal Anomalies Observed in Fargo House 非 1

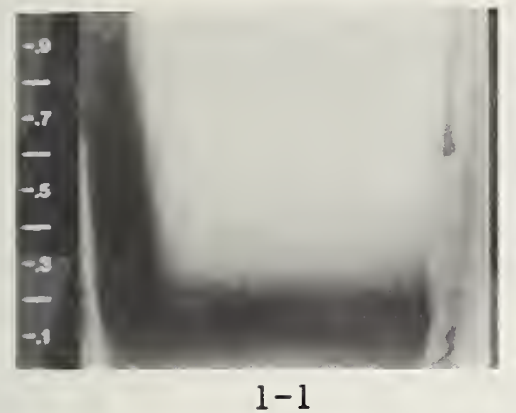

Solar Effect on

'hollow' front door. (by contractor 非3)

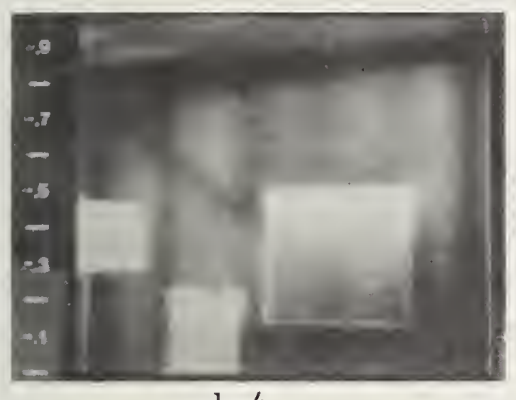

$1-4$

$W$ corner on $W$

of living room.

(by NBS)

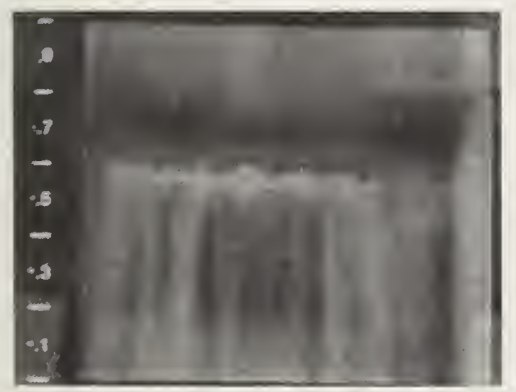

$$
\text { 1-7 }
$$

Above window \& at ceiling of bathroom. (by NBS)

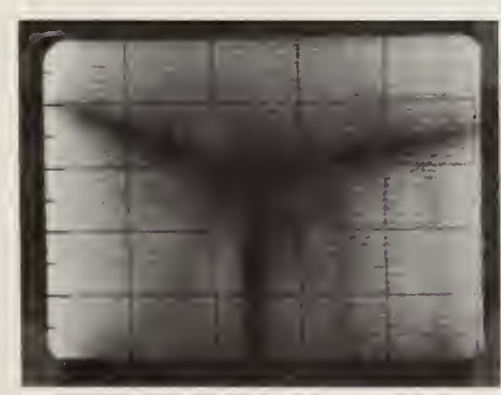

$$
1-10
$$

SE corner of

SE bedroom.

(by contractor 非)

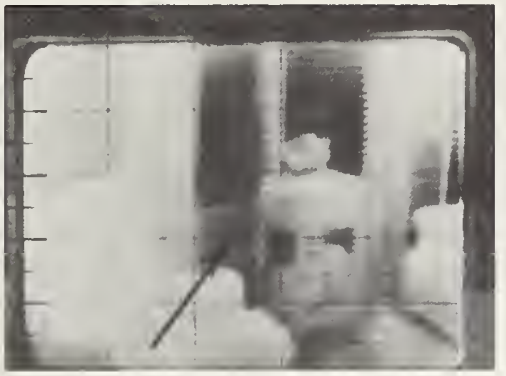

$$
\text { 1-2 }
$$

SE corner on $\mathrm{S}$

of living room.

(by contractor 非)

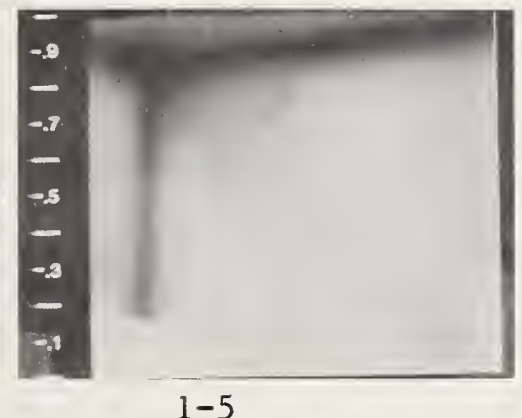

SW corner on $W$

of living room.

(by contractor 非3)

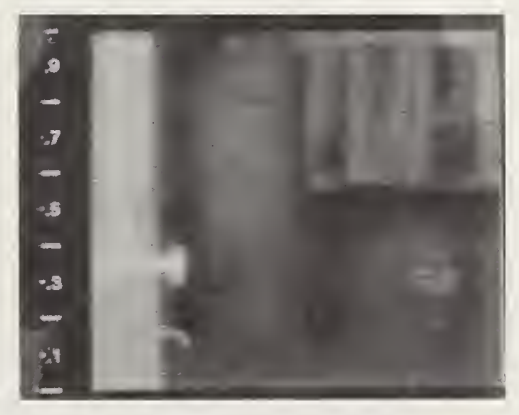

$$
\text { 1-8 }
$$

Below window of bathroom.

(by NBS)

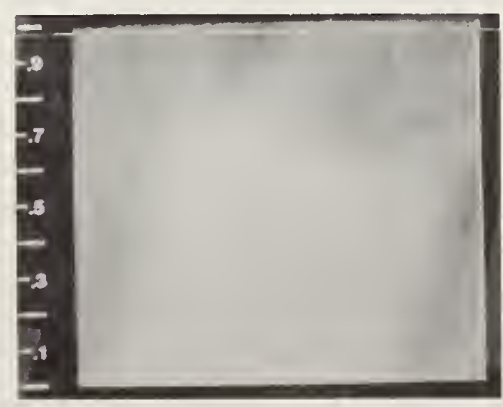

$1-11$

Solar effect at the attic ceiling.

(by contractor 非3)

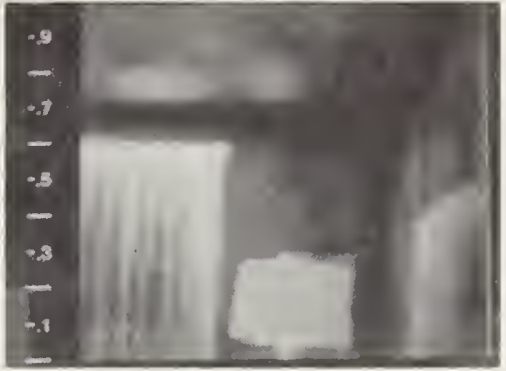

$1-3$

SW corner on S of living room.

(by NBS)

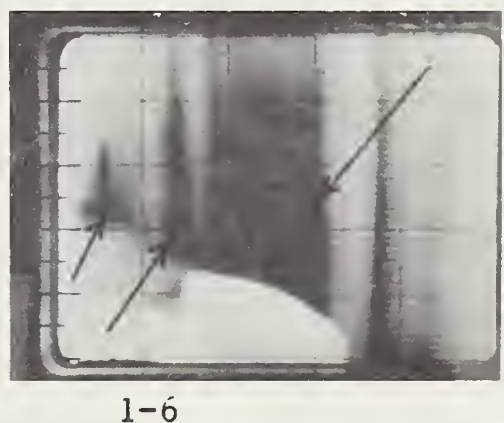

'Hollow' side door scanned at overcast. (by contractor 非)

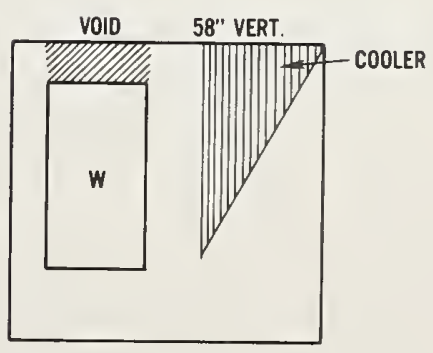

$$
\text { 1-9 }
$$

$E$ wall of $S E$

bedroom. (by LRIS) 



\section{Fargo House \#2}

This is a one-story, approximately 50 year old residence whose interior dimensions are $36 \mathrm{ft}$. In length, $19 \mathrm{ft}$. in width, and $8 \mathrm{ft}$. in wall height; located in Fargo, ND. There are 6 rooms of living space, with an attic and a basement. Its exterior construction contains wood siding and a cedar shingle roof.

Prior to the weatherization program, this house had no insulation. An insulation contractor was instructed to insulate the walls of this house with UF foam. After the retrofitted foam was injected into the walls, this dwelling was inspected by NBS personnel and IR contractors \#1, \#2, and \#3. A sketch of the voids and the locations of heat loss obtained from thermograms and documents by NBS, as well as those by the IR contractors, is shown in figure IIa.

In general, the most common area showing heat loss in this house were found on both the east and west sides. The voids in these walls may be due to poor installation or extreme shrinkage of foam. The north wall enclosed by the porch was not insulated since insulation was supposed to be added to the outside walls of the house. The outer walls of the porch were not inspected because the porch was not heated. Hence this wall was omitted in area calculations.

Thermographic inspection by NBS missed the data on east walls of the bathroom and the northeast bedroom due to camera malfunction. Therefore, its results can not serve as a baseline for these two walls.

Contractors $\# 1$ and $\# 2$ identified a11 defective wal1 areas while contractor \#3 missed a few locations. In addition, contractors $\#_{2}$ and 3 included inspections of the celling of the dining room and found that the insulation in the ceiling was not adequate.

A detailed description of the defects observed by NBS as well as thoe by the IR contractors, is summarized in table IIa. Besides the total defective wall area in $\mathrm{ft}^{2}$ found by each inspection, table IIa also includes the defective wall areas in $\mathrm{ft}^{2}$ of each room of the house, analyzed from available thermograms and sketches. The total estimates of vold areas is approximately $78 \mathrm{ft}^{2}$, which represents about 9 percent of the gross wall area. Table IIb presents the environmental conditions documented from each inspection. Thermograms/sketches 2-1 to 2-7 are some examples which demonstrate the locations of heat loss anomalies, as they are referred to in the descriptions in table IIa. 

Table IIa. Summary of Defects Observed in Fargo House \#2

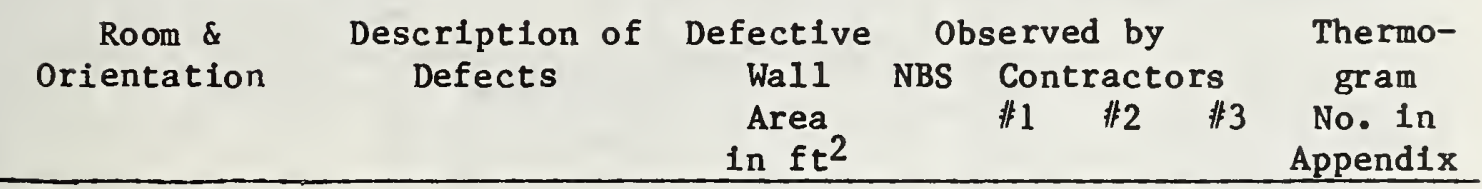

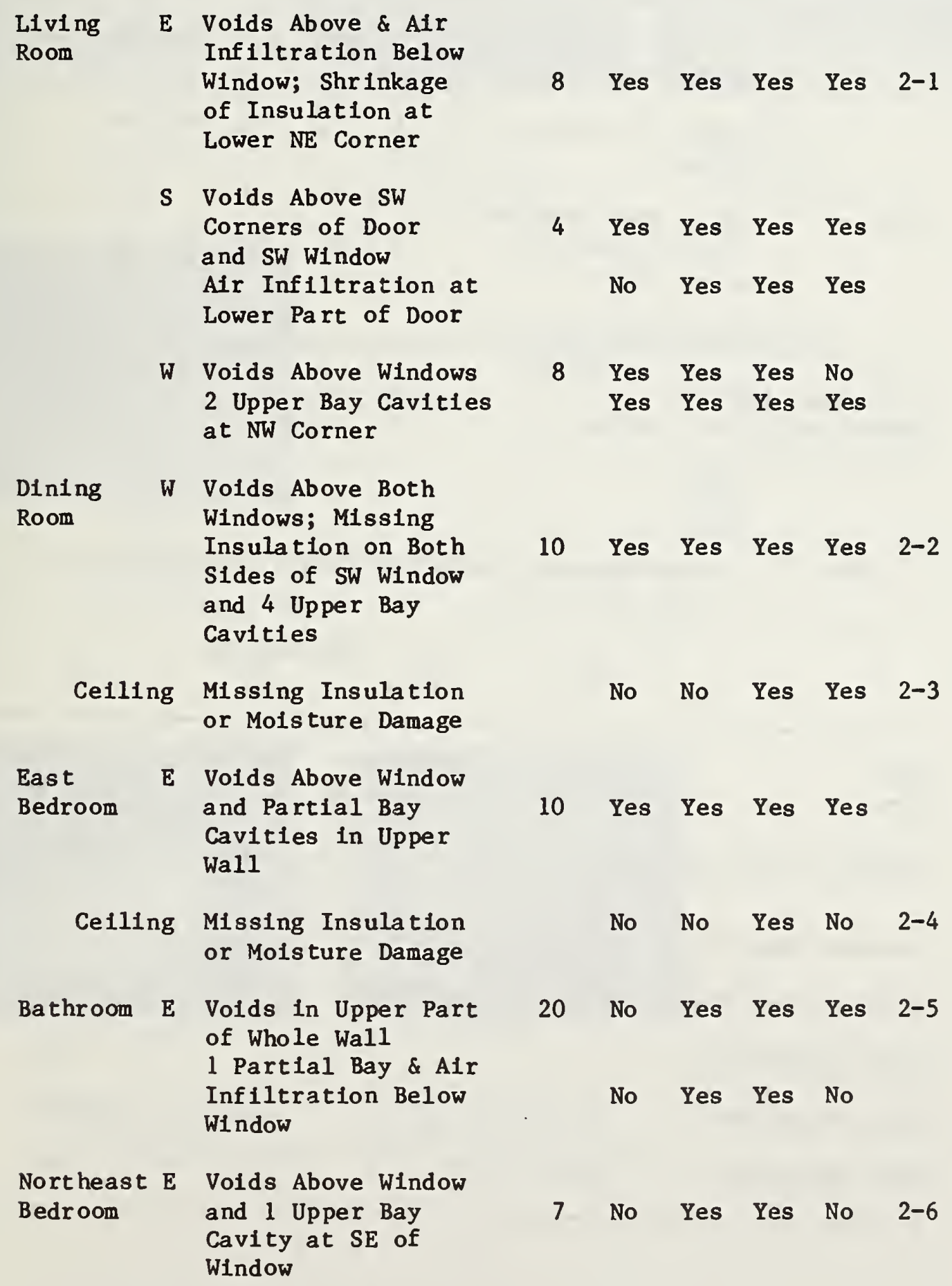


Table IIa. Summary of Defects Observed in Fargo House \#2

Room \& Description of Defective Observed by ThermoOrientation Defects Wall NBS Contractors gram

\begin{tabular}{|c|c|c|c|c|c|c|c|c|}
\hline & & \multicolumn{3}{|c|}{$\begin{array}{c}\text { Area } \\
\text { in } \mathrm{ft}^{2} \\
\end{array}$} & $\# 1$ & $\# 2$ & $\# 3$ & $\begin{array}{l}\text { No. In } \\
\text { Appendix }\end{array}$ \\
\hline & & $\begin{array}{l}\text { Volds \& Infiltration } \\
\text { Below Window }\end{array}$ & & No & Yes & Yes & No & $2-7$ \\
\hline & $\mathbf{N}$ & $\begin{array}{l}\text { Small Void Above } \\
\text { Window }\end{array}$ & 2 & Yes & Yes & Yes & No & \\
\hline KItchen & W & $\begin{array}{l}\text { Voids Above Window } \\
\text { \& Under Cabinets } \\
\text { at NW Corner }\end{array}$ & 9 & No & Yes & Yes & No & \\
\hline
\end{tabular}

Total Area Wall of

Insulation Volds Detected

$\begin{array}{lllll}78 & 42 & 78 & 78 & 50\end{array}$

Given in $\mathrm{ft}^{2}$

Table IIb. Environmental Conditions During Inspections of Fargo House \#2

\begin{tabular}{|c|c|c|c|c|}
\hline & NBS & Cont & $\begin{array}{c}\text { ractors } \\
\# 2\end{array}$ & $\# 3$ \\
\hline $\begin{array}{l}\text { Date } \\
\text { Time }\end{array}$ & $\begin{array}{r}3 / 2 / 79 \\
2: 00 \mathrm{pm}\end{array}$ & $\begin{array}{r}4 / 10 / 79 \\
8: 15-9: 15 \mathrm{pm}\end{array}$ & $4 / 26 / 79$ & $\begin{array}{l}4 / 17 / 79 \\
1: 15 \mathrm{pm}\end{array}$ \\
\hline Weather Condition & & & $\begin{array}{l}\text { light } \\
\text { snow }\end{array}$ & $\begin{array}{l}\text { bright } \\
\text { sunhine }\end{array}$ \\
\hline Outdoor Temperature & $15^{\circ} \mathrm{F}$ & $37^{\circ} \mathrm{F}$ & $38^{\circ} \mathrm{F}$ & $59^{\circ} \mathrm{F}$ \\
\hline Indoor Temperature & $75^{\circ} \mathrm{F}$ & $77^{\circ} \mathrm{F}$ & $78^{\circ} \mathrm{F}$ & $71^{\circ} \mathrm{F}$ \\
\hline Indoor Humidity & & & & $53 \%$ \\
\hline Wind Speed(MPH) & $2-5$ & & calm & $20-25$ \\
\hline Wind Direction & NW & & & $S E$ \\
\hline
\end{tabular}


Thermal Anomalies Observed in Fargo House 非2

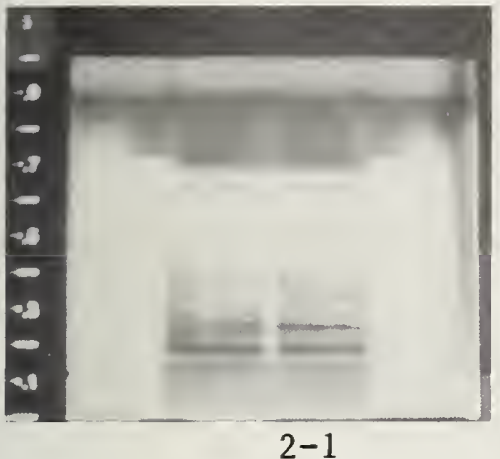

E wall of

living room.

(by NBS)

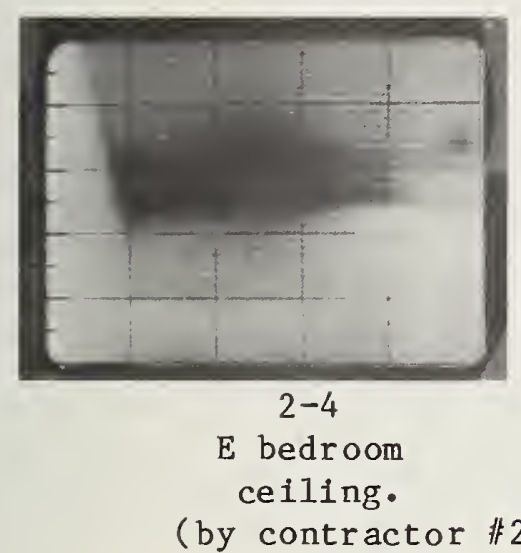

(by contractor 非)

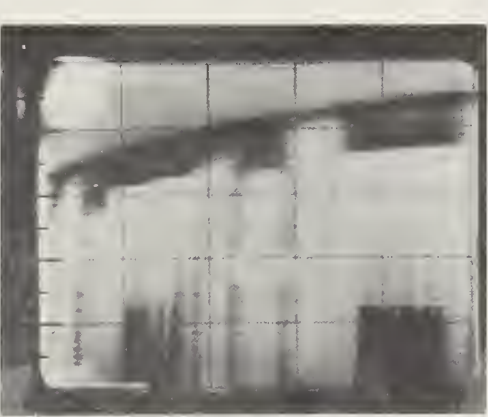

2-2

W wall of

dining room.

(by contractor 非)

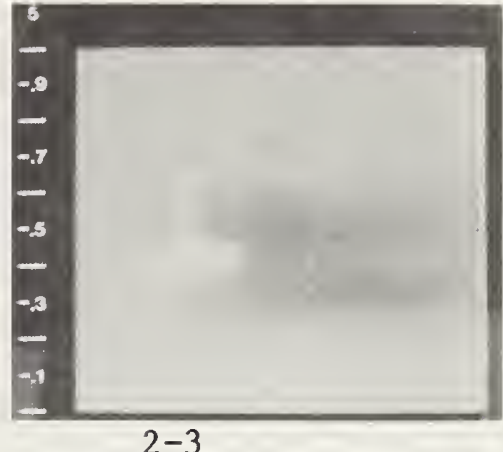

Dining room ceiling. (by contractor 非3)

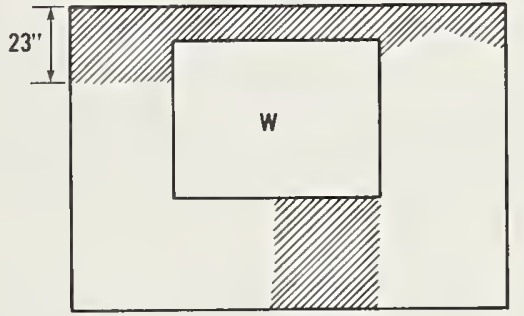

OTI voIDs

2-5

E wall of bathroom. (by LRIS)

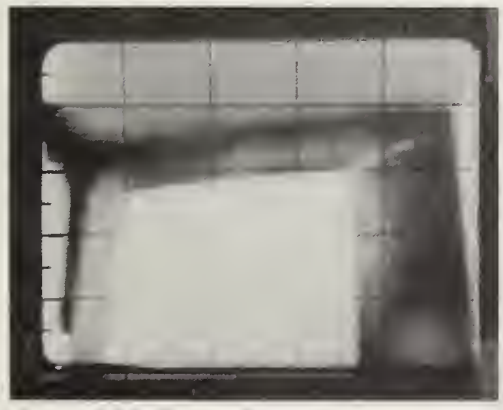

$2-6$

Upper $\mathrm{E}$ wall of NE bedroom. (by contractor 非)

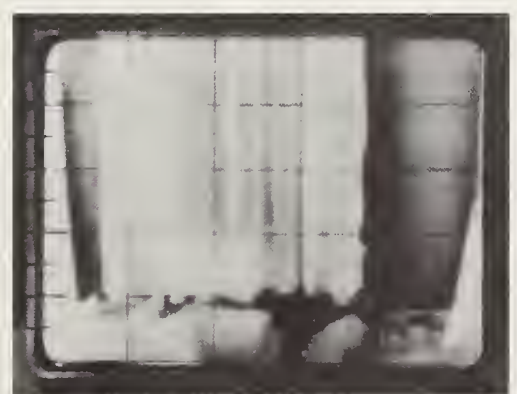

$2-7$

Lower E wall of NE bedroom. (by contractor 非) 



\section{Fargo House \#3}

This is a one-story, approximately 60 year old residence whose interior dimensions are $34 \mathrm{ft}$. In length, $24 \mathrm{ft}$. In width, and $8 \mathrm{ft}$. In wall helght; located in Fargo, ND. There are 6 rooms of living space, with an attic and a basement. Its exterior construction contains wood frame with aluminum siding, and an asphalt shingle roof.

Prior to the weatherization program, this house had no insulation. An insulation contractor was instructed to insulate the walls of this house with UF foam. After retrofitted foam was injected into the walls, this dwelling was inspected by NBS personnel and IR contractors 1 , \#2, and \#3. A sketch of the voids and the locations of heat loss obtained from thermograms and documents by NBS, as well as those by the IR contractors, is shown in figure IIIa.

In general, the most common area of heat loss in this house were found above windows, doors, and eaves as well as alr leakage paths below windows.

Thermographic inspection by NBS Identifled most known defects of this residence so that its results can be used as a baseline for comparison. Furthermore, NBS included scanning of the basement walls which were colder at the top. Since the top part of the basement is above ground and the bottom part is under ground, there seemed to be cold air penetration to the basement from outside.

Contractors $\mathbb{1}_{1}$ and $\# 2$ each missed inspection of a few locations, but contractor \#2 inspected the dining room celling and found some volds at the celling, the west partition wall of the dining room, and the north partition wall of the bathroom. However, these volds were not included in calculations for defects.

Contractor \#3 scanned this dwelling under bright sunlight so that the high temperature areas do indicate vold areas due to the high temperature from solar

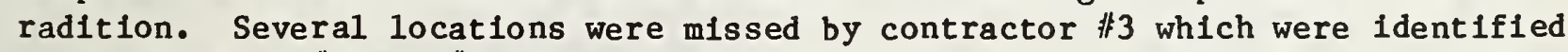
by contractors $\|_{1}$ and $\left.\right|_{2}$ as well as NBS.

A detalled description of the defects observed by NBS as well as those by the IR contractors, is summarized in table IIIa. Besides the total defective wall area in $\mathrm{ft}^{2}$ found by each inspection, table IIIa also includes the defective wall areas in $\mathrm{ft}^{2}$, of each room of the house, analyzed from avallable thermograms and sketches. The total estimates of vold areas is approximately $75 \mathrm{ft}^{2}$, which represents about 10 percent of the gross wall area. Table IIIb presents the environmental conditions documented from each inspection. Thermograms/ sketches 3-1 to 3-12 are some examples which demonstrate the locations of heat loss anomalies, as they are referred to in descriptions in table IIIa. 

Table IIIa. Summary of Defects Observed 1n Fargo House 非3

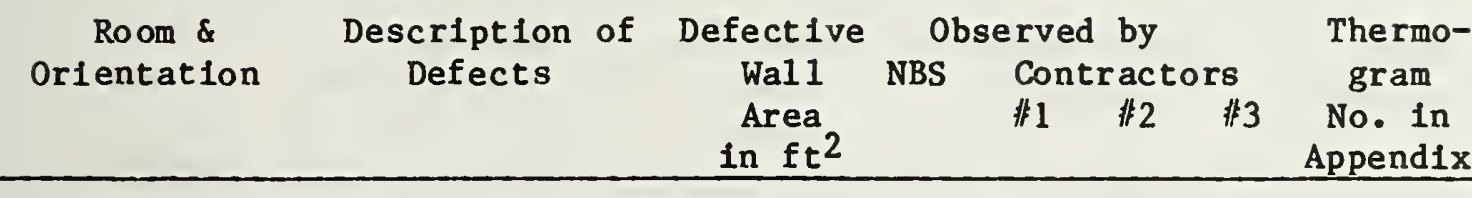

\begin{tabular}{|c|c|c|c|c|c|c|c|}
\hline $\begin{array}{l}\text { Living } \\
\text { Room }\end{array}$ & $\mathrm{N}$ & $\begin{array}{l}\text { Volds Above Window } \\
\text { and Door }\end{array}$ & 10 & Yes & Yes & Yes & No \\
\hline & & $\begin{array}{l}1 \text { Upper Bay Cavity } \\
\text { at NE of Window \& } \\
\text { Alr Infiltration } \\
\text { Around Door }\end{array}$ & & Yes & Yes & Yes & Yes \\
\hline & E & $\begin{array}{l}\text { Volds Above Window } \\
\text { and } 2 \text { Upper Bay } \\
\text { Cavities at SE of } \\
\text { Window }\end{array}$ & 8 & Yes & Yes & Yes & Yes \\
\hline $\begin{array}{l}\text { Dining } \\
\text { Room }\end{array}$ & E & $\begin{array}{l}\text { Voids In Upper Part } \\
\text { of the Entire Wall }\end{array}$ & 17 & Yes & Yes & Yes & No \\
\hline & & $\begin{array}{l}1 \text { Bay Cavity at } \mathrm{NE} \\
\text { Corner \& Infiltration } \\
\text { Below Window }\end{array}$ & & Yes & Yes & No & No \\
\hline & W & $\begin{array}{l}\text { Volds in Partition } \\
\text { Wall \& Cold Celling }\end{array}$ & & No & No & Yes & No \\
\hline
\end{tabular}

Kitchen E Volds Above Window and Infiltration 7 Yes No No No

Below Window

Volds Above and at NE

Side of Near Door;

Alr Infiltration at

SE Corner

S Air Penetration \& Volds Below Window

Yes No No No

Northeast $\mathrm{N}$ Volds Above Window Bedroom

and in 2 Upper

Bays at NE Corner

8 Yes Yes Yes No 3-6

W Volds In 1 Upper Bay 1 Yes Yes Yes Yes

Alr Penetration at

Lower NW Corner

Yes No No No 
Table IIIa. Summary of Defects Observed in Fargo House \#3

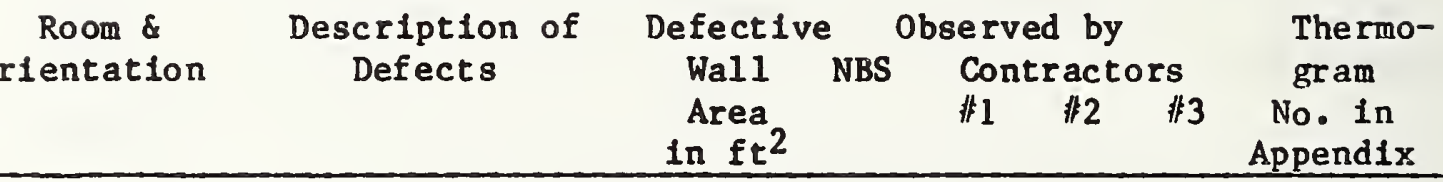

\begin{tabular}{|c|c|c|c|c|c|c|c|c|}
\hline Bathroom & $W$ & $\begin{array}{l}\text { Voids Above Window } \\
\text { and in } 2 \text { Upper Bays } \\
\text { at Both Sides of } \\
\text { Window }\end{array}$ & 10 & Yes & Yes & Yes & No & \\
\hline & $\mathbf{N}$ & $\begin{array}{l}\text { Some Volds in } \\
\text { Partition Wall }\end{array}$ & & No & No & Yes & No & \\
\hline \multirow[t]{2}{*}{$\begin{array}{l}\text { Sout hwest } \\
\text { Bedroom }\end{array}$} & W & $\begin{array}{l}\text { Voids Above Window } \\
\text { and in } 3 \text { Upper Bays } \\
\text { at SW Corner }\end{array}$ & 8 & Yes & Yes & Yes & Yes & $\begin{array}{l}3-7 \\
3-8 \\
3-9\end{array}$ \\
\hline & $\mathbf{S}$ & $\begin{array}{l}\text { Volds at SW Corner } \\
\text { of Window }\end{array}$ & 4 & Yes & No & No & Yes & \\
\hline Basement & & $\begin{array}{l}\text { Cold Air Penetrated } \\
\text { From Outside at Top } \\
\text { of Wall }\end{array}$ & & Yes & No & No & No & $\begin{array}{l}3-10 \\
3-11 \\
3-12\end{array}$ \\
\hline
\end{tabular}

Total Wall Area of

$\begin{array}{lllll}75 & 75 & 60 & 59 & 23\end{array}$

Insulation Voids Detected Given in $\mathrm{ft}^{2}$ 
Table IIIb. Environmental Conditions During Inspection of Fargo House 非

\begin{tabular}{|c|c|c|c|c|}
\hline & NBS & 非 & $\begin{array}{c}\text { ontractors } \\
\text { \#2 }\end{array}$ & 非3 \\
\hline $\begin{array}{l}\text { Date } \\
\text { Time }\end{array}$ & $\begin{array}{l}3 / 1 / 79 \\
2: 00 \mathrm{pm}\end{array}$ & $\begin{array}{c}4 / 9 / 79 \\
7: 00-8: 00 \mathrm{pm}\end{array}$ & $4 / 25 / 79$ & $\begin{array}{c}4 / 17 / 79 \\
12: 00 \text { noon }\end{array}$ \\
\hline Weather Condition & & & cloudy & $\begin{array}{l}\text { bright } \\
\text { sunlight }\end{array}$ \\
\hline Outdoor Temperature & $15^{\circ} \mathrm{F}$ & $35^{\circ} \mathrm{F}$ & $41^{\circ} \mathrm{F}$ & $56^{\circ} \mathrm{F}$ \\
\hline Indoor Temperature & $79^{\circ} \mathrm{F}$ & $72^{\circ} \mathrm{F}$ & $69^{\circ} \mathrm{F}$ & $78^{\circ} \mathrm{F}$ \\
\hline Indoor Humidity & & & & $40 \%$ \\
\hline Wind Speed (MPH) & $5-10$ & & $8-12$ & $20-25$ \\
\hline Wind Direction & NW & & $\mathrm{N}$ & SE \\
\hline
\end{tabular}



Thermal Anomalies Observed in Fargo House 非

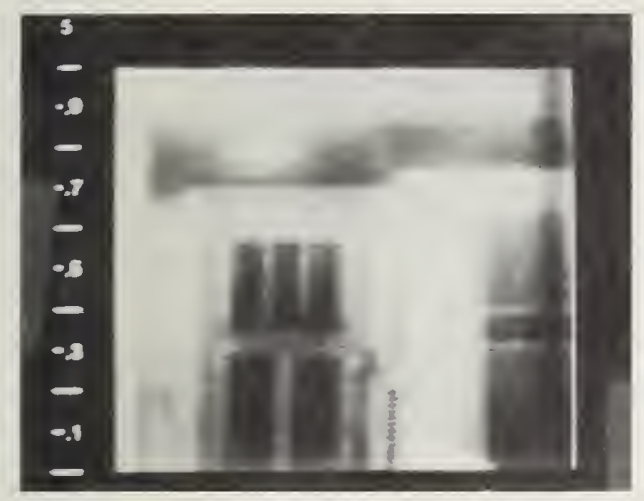

3-1

$\mathrm{N}$ wall of

living room.

(by NBS)

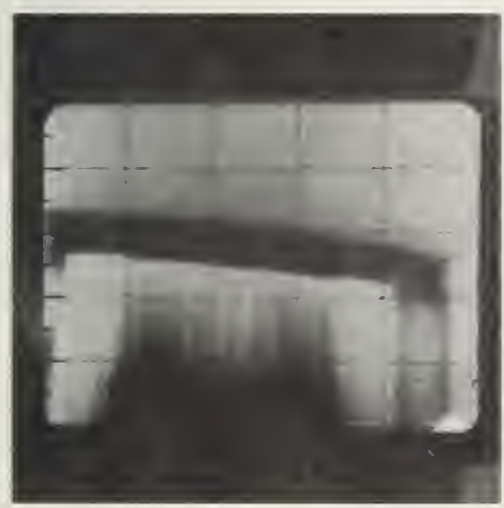

$$
\text { 3-3 }
$$

E wall of

dining room.

(by contractor $\#_{2}$ )

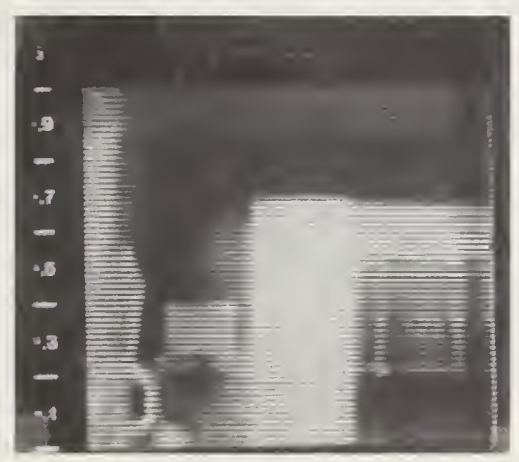

$$
\text { 3-4 }
$$

$\mathrm{NE}$ corner on $\mathrm{E}$

of dining room.

(by NBS)

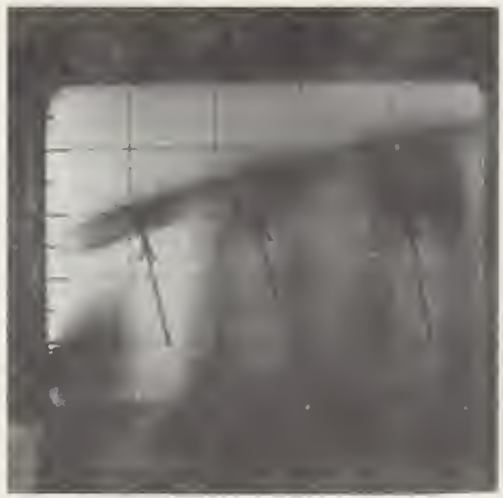

$3-2$

$E$ wall of

living room.

(by contractor 非)

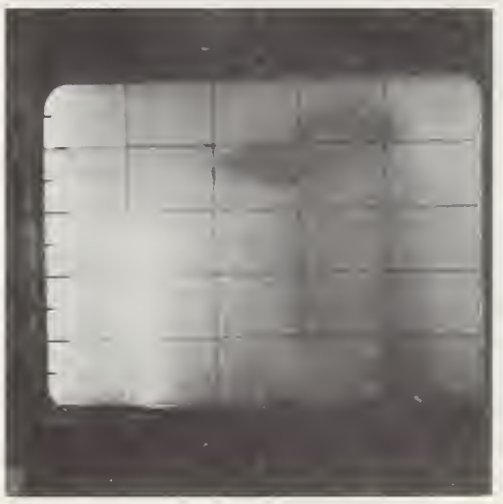

$$
3-5
$$

Ceiling \& $W$ wall of dining room.

(by contractor 非)

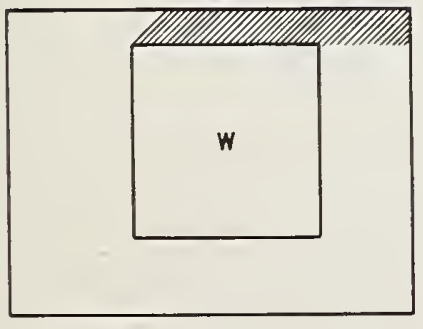

3-6

$\mathrm{N}$ wall of NW bedroom. (by LRIS)

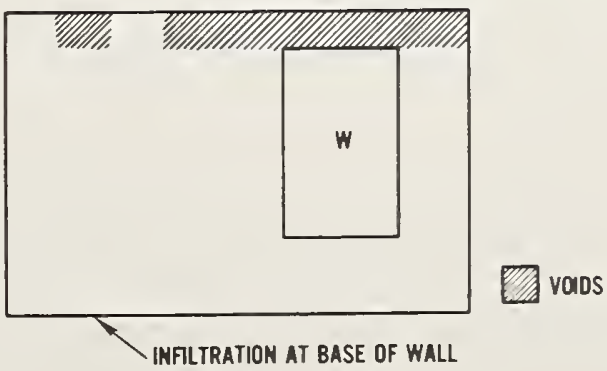

3-7

W wall of SW bedroom. (by LRIS) 

Thermal Anomalies Observed in Fargo House 非3 (continued)

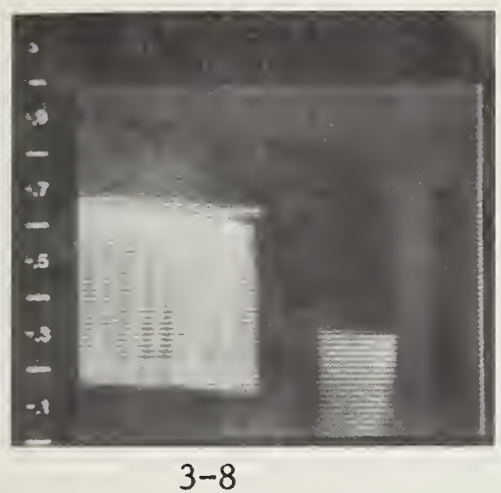

SW corner of SW bedroom. (Scanned at overcast by NBS)

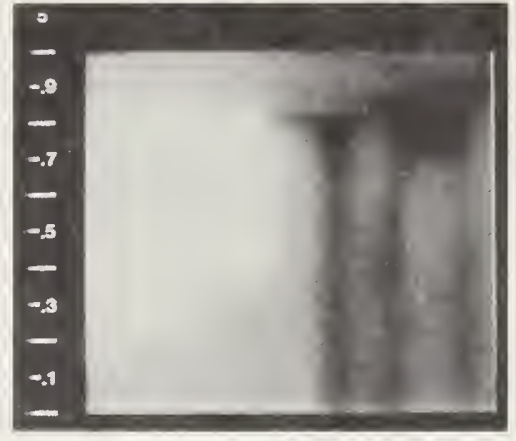

SW corner of SW bedroom (Scanned under bright sunlight by contractor 非3)

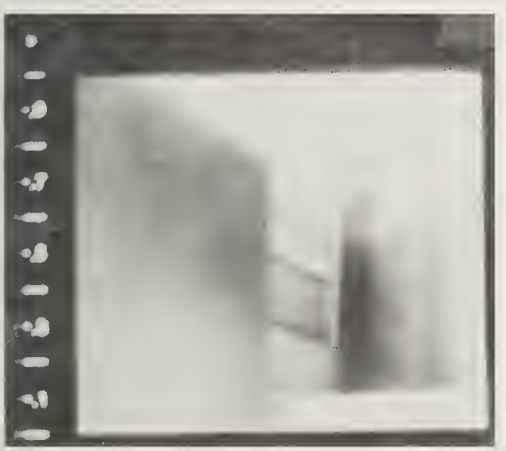

$3-10$

At basement door. (by NBS)

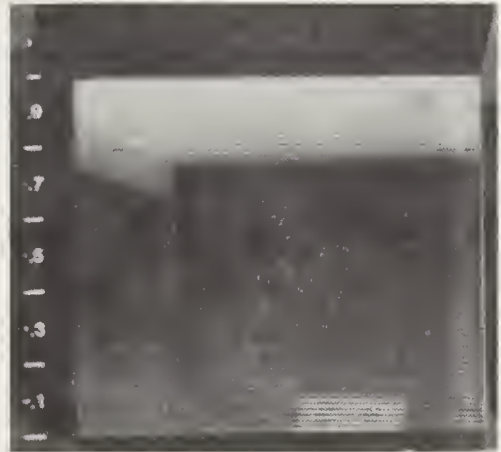

3-11

NW corner of basement. (by NBS)

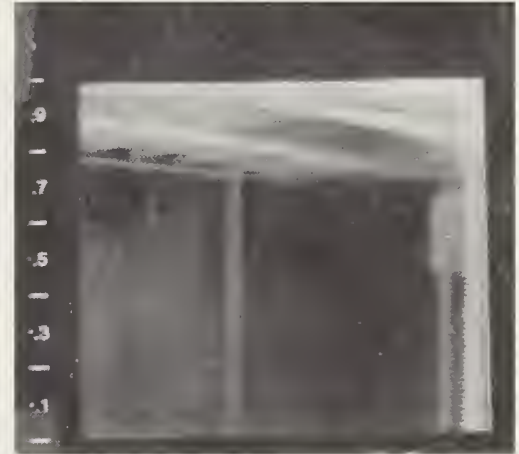

3-12

NE corner of basement. (by NBS) 



\section{Fargo House \#4}

This is a one-story, approximately 15 year old residence whose interior dimensions are $23 \mathrm{ft}$. In length, $21 \mathrm{ft}$. in width, and $8 \mathrm{ft}$. in wall height; located in Fargo, ND. There are 4 rooms of living space with an attic and a basement. Its exterior construction contains wood frame with wood lap siding and an asphalt shingle roof.

Prior to the weatherization program, this house was insulated with 3 and $1 / 2$ ' glass fiber batt insulation in the cavity walls. An insulation contractor was instructed to add UF foam to the existing insulation. After the retrofitted foam was injected into the walls, this dwelling was inspected by NBS personnel and IR contractors $\# 1$, 非, and 33 . A sketch of the voids and the locations of heat loss obtained from thermograms and documents by NBS as well as those by the IR contractors, is shown in figure IVa.

In general, the most common area of heat loss in this house were found above most windows and doors, and below most of the windows. The corner of the wallceiling joints were also defective with several vertical partially-voided corner bays. Problem areas may be due to the insulation defects at the eaves underneath the roof and compression of old insulation as well as missed foaming. These were loose fitting paneling in the bathroom and a moisture problem in the attic. Both doors were found to be uninsulated with severe air leakage ar ound them.

Thermographic inspection by NBS observed most known defects of this residence except of the south entrance. Contractor $\left.\right|^{2}$ also included all defects except for the east wall of the living room. Therefore, from the combination of these two inspections, a baseline were established for comparison purposes.

From contractor 非's comment, the thermal pattern observed in this house was due to: (1) damp insulation, (2) uneven application of foaming (different density), and (3) foam mixed with other kind of insulation, providing areas of different $\mathrm{R}-\mathrm{values}$. Therefore, it claimed that no volds were found in this house. However, this house did have insulation before and the inspection should be locating voids in the foam retrofits. Hence the 'cool area' indicated by contractor $\#_{1} 1$ should be considered as defects, misses, or shrinkage of foaming. The cool areas found by contractor \#1 were interpreted as voids in the house. However contractors $\|_{1} 1$ and 3 failed to inspect many areas in this dwelling.

A detailed description of the defects observed by NBS as well as those by the IR contractors, is summarized in table IVa. Besides the total defective wall area in $\mathrm{ft}^{2}$ found by each inspection, table IVa also includes the defective wall areas in $\mathrm{ft}^{2}$ of each room of the house, analyzed from available thermograms. The total estimates of void areas is approximately $67 \mathrm{ft}^{2}$, which represents about 11 percent of the gross wall area. Table IVb presents the environmental conditions documented from each inspection. Thermograms 4-1 to 4-8 are some examples which demonstrate the locations of heat loss anomalies, as they are referred to in the descriptions in table IVa. 


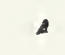


Table IVa. Summary of Defects Observed in Fargo House \#4

\begin{tabular}{|c|c|c|c|c|c|c|}
\hline Room \& & Description of & Defective & $=0$ & served b & & The rmo- \\
\hline Orientation & Defects & Wal1 & NBS & Contrac & & gram \\
\hline & & $\begin{array}{l}\text { Area } \\
\text { in } f t^{2}\end{array}$ & & 非1 & \#3 & $\begin{array}{l}\text { No. in } \\
\text { Appendix }\end{array}$ \\
\hline
\end{tabular}

\begin{tabular}{|c|c|c|c|c|c|c|c|c|}
\hline \multirow[t]{3}{*}{$\begin{array}{l}\text { Living } \\
\text { Room }\end{array}$} & $\mathrm{E}$ & $\begin{array}{l}\text { Air Penetration } \\
\text { from Ceiling and } \\
\text { Infiltration Around } \\
\text { 'Hollow' Door }\end{array}$ & 5 & Yes & Yes & Yes & Yes & \\
\hline & & $\begin{array}{l}\text { Voids Above Window } \\
1 \text { Half Bay Cavity } \\
\text { and Infiltration } \\
\text { at NE Corner }\end{array}$ & & Yes & Yes & No & Yes & \\
\hline & $\mathrm{N}$ & $\begin{array}{l}1 \text { Half Bay Cavity } \\
\text { at NW Corner } \\
\text { Voids Above Window; } \\
\text { Missing Foam In } \\
\text { Several Upper Bays } \\
\text { and Infiltration at } \\
\text { Ceiling-Wall Joint }\end{array}$ & 12 & Yes & Yes & Yes & Yes & $4-2$ \\
\hline \multirow[t]{2}{*}{ Bathroom } & E & $\begin{array}{l}\text { Voids Below Window } \\
\text { Voids Above Window } \\
\text { and in } 1 \text { Upper Bay } \\
\text { at NE Corner }\end{array}$ & 6 & Yes & Yes & Yes & Yes & $4-3$ \\
\hline & $S$ & $\begin{array}{l}\text { Partial Bay Cavities } \\
\text { at SE Corner; Missing } \\
\text { a Good Deal of Foam } \\
\text { in Wall }\end{array}$ & 7 & Yes & No & Yes & No & \\
\hline \multirow[t]{2}{*}{$\begin{array}{l}\text { South } \\
\text { ENTRANCE }\end{array}$} & $S$ & $\begin{array}{l}\text { Volds Above Door \& } \\
\text { Alr Penetration } \\
\text { Through Attic Hatch }\end{array}$ & 4 & No & Yes & Yes & No & $4-4$ \\
\hline & & $\begin{array}{l}\text { Alr Leakage Around \& } \\
\text { Penetration Tthrough } \\
\text { 'Hollow' Door }\end{array}$ & & No & No & Yes & Yes & $4-5$ \\
\hline Kitchen & $W$ & $\begin{array}{l}\text { Voids Above and } \\
\text { Below Window }\end{array}$ & & Yes & Yes & Yes & No & \\
\hline
\end{tabular}


Table IVa. Summary of Defects Observed in Fargo House \#4

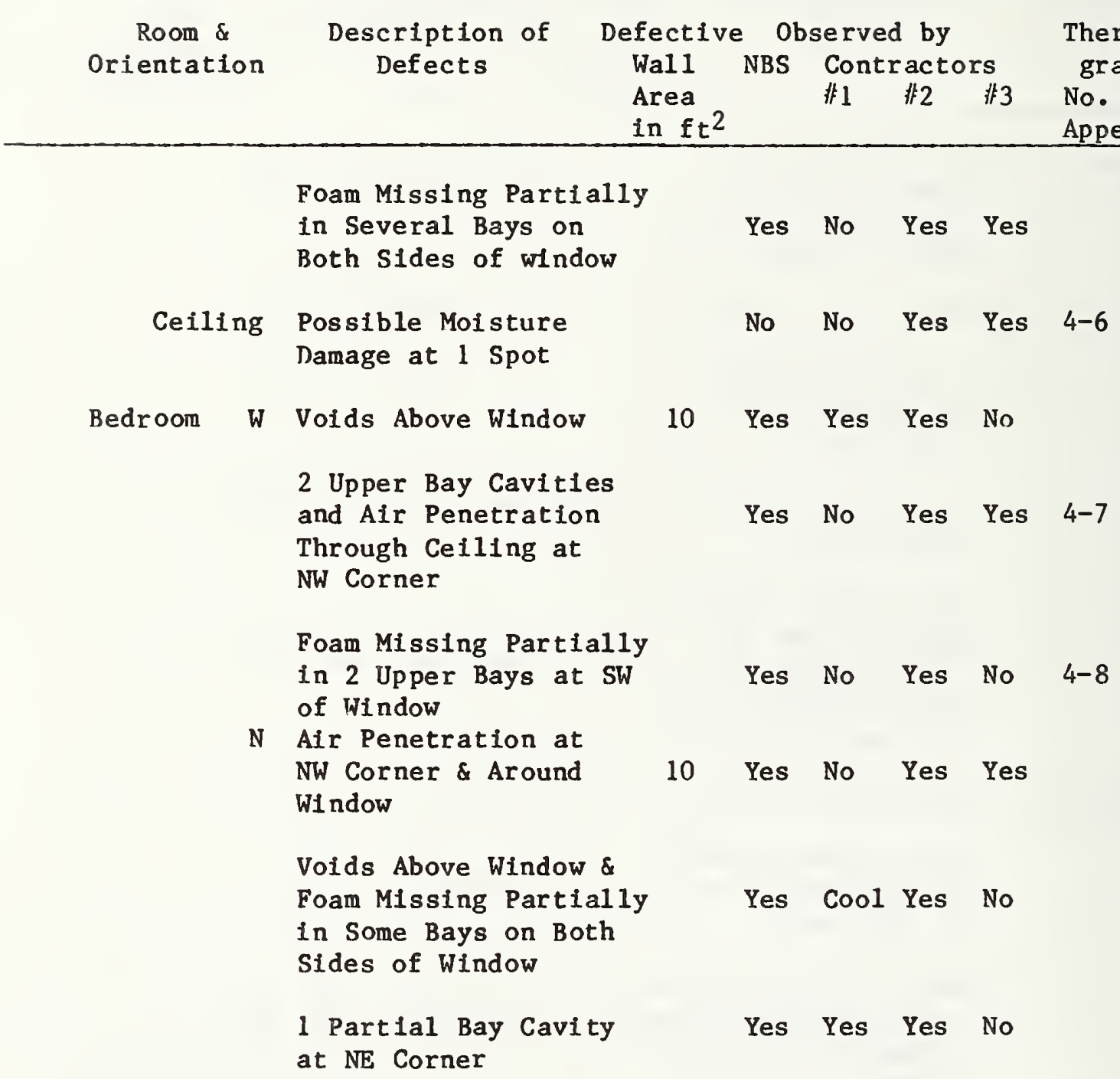

Total Wall Area of

$\begin{array}{lllll}67 & 63 & 34 & 62 & 38\end{array}$

Insulation Voids Detected

Given in $\mathrm{ft}^{2}$ 
Table IVb. Environmental Conditions During Inspection of Fargo House \#4

\begin{tabular}{|c|c|c|c|c|}
\hline & & Con & ractors & \\
\hline & NBS & $\# 1$ & \#2 & \#3 \\
\hline $\begin{array}{l}\text { Date } \\
\text { Time }\end{array}$ & $\begin{array}{l}3 / 2 / 79 \\
4: 00 \mathrm{pm}\end{array}$ & $\begin{array}{c}4 / 9 / 79 \\
8: 15-9: 15 \mathrm{pm}\end{array}$ & $4 / 25 / 79$ & $\begin{array}{l}4 / 17 / 79 \\
2: 45 \mathrm{pm}\end{array}$ \\
\hline Weather Condition & & & overcast & $\begin{array}{l}\text { bright } \\
\text { sunshine }\end{array}$ \\
\hline Outdoor Temperature & $13^{\circ} \mathrm{F}$ & $35^{\circ} \mathrm{F}$ & $37^{\circ} \mathrm{F}$ & $59^{\circ} \mathrm{F}$ \\
\hline Indoor Temperature & $75^{\circ} \mathrm{F}$ & $75^{\circ} \mathrm{F}$ & $76^{\circ} \mathrm{F}$ & $79^{\circ} \mathrm{F}$ \\
\hline Indoor Humidity & & & & $51 \%$ \\
\hline Wind Speed (MPH) & $5-10$ & & $3-5$ & $25-35$ \\
\hline Wind Direction & NW & & $\mathbf{S}$ & SE \\
\hline
\end{tabular}





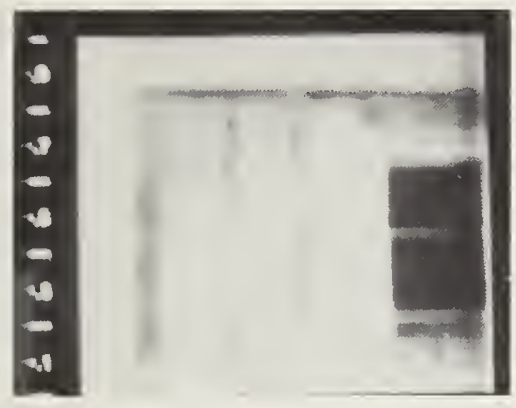

4-1

NW corner on $N$ of living room. (Different density levels of insulation by NBS)

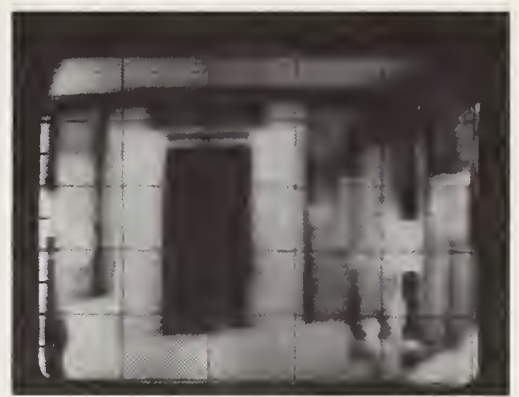

$$
\text { 4-2 }
$$

$\mathrm{N}$ wall of living room. (Different density levels of insulation by contractor 非)

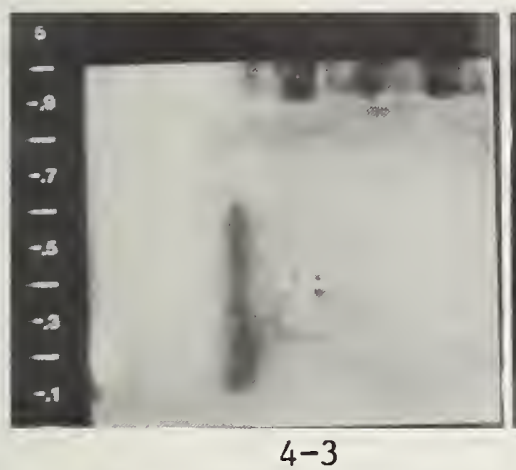

Below window on $E$ of bathroom. (by contractor 非)

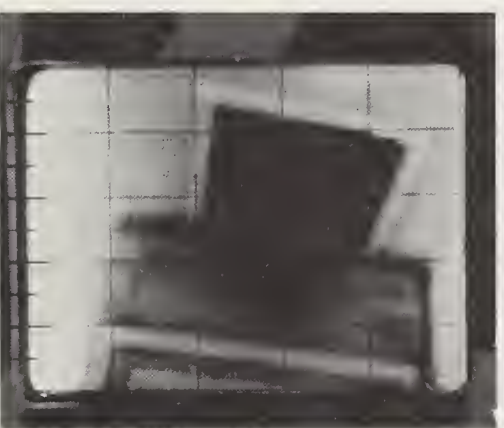

4-4

Attic hatch \& above side door. (by contractor 非)

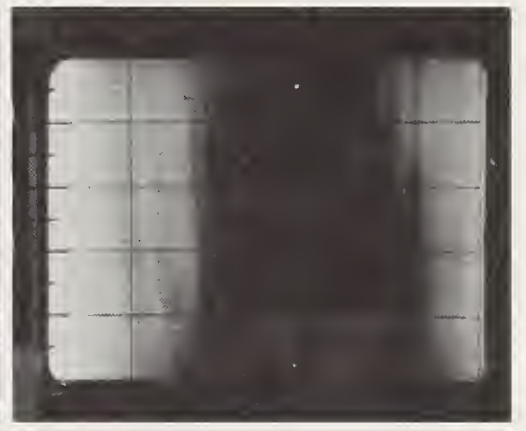

4-5

Infiltration around \& underneath side door. (by contractor 非)

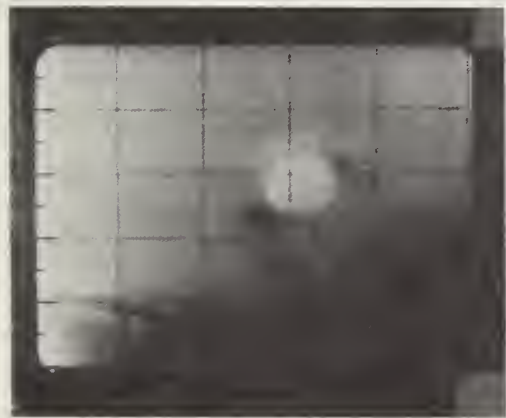

$$
\text { 4-6 }
$$

Problems at kitchen ceiling. (by contractor 非)

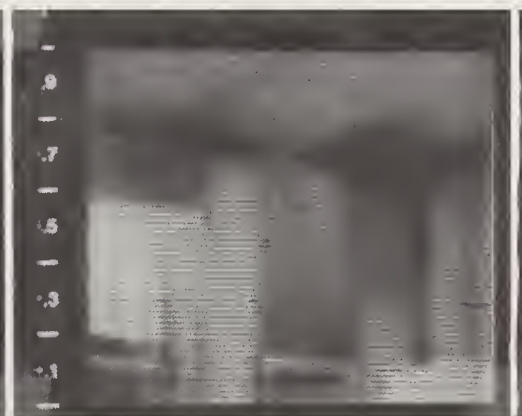

$$
\text { 4-7 }
$$

NW corner on $W$ of bedroom. (by NBS)

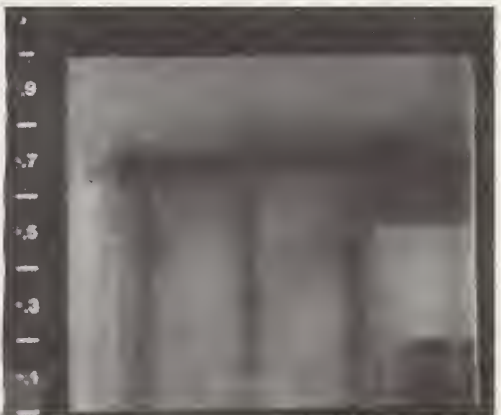

$$
\text { 4-8 }
$$

SW corner on $W$ of bedroom. (by NBS) 



\section{Minneapolis-St. Paul House 非 1}

This is a two-story, approximately 60 year old residence whose interior dimensions are $33 \mathrm{ft}$. In length, $30 \mathrm{ft}$. in width, and $9 \mathrm{ft}$. in wall height on the first floor, and $8 \mathrm{ft}$. in wall height on the second floor; located in Minneapolis-St. Paul, MN. There are 8 rooms of living space, with an attic and a basement. Its exterior construction contains wood frame with stucco siding and an asphalt shingle roof.

Prior to the weatherization program, this house had no insulation. An insulation contractor was instructed to insulate the walls of this dwelling with UF foam. After retrofitted foam was injected into the walls, this dwelling was inspected by NBS personnel and IR contractors 非, and 非. A sketch of the volds and locations of heat loss obtained from thermograms and documents by NBS as well as those by the IR contractors, is shown in figures Va and Vb.

In general, voids in this house were found above most of the windows and doors, and these locations were also sites of alr leakage. The wall and ceiling joints have thermal bridges with infiltration, and bay cavities were also found at wallto-wall joints. Several walls on the second floor were found to have foam shrinkage.

Thermographic inspection by NBS revealed most of the defects of this residence, except for those in the north upstairs room. Furthermore, NBS carried out both interior and exterior inspections of this house. Besides giving the correct location of the fireplace chimney, the exterior thermograms illustrated some defects on the west wall of the southwest bedroom where no interior thermograms were produced. Therefore, results of NBS' inspection were used as a baseline for comparison purposes.

Contractors $\#_{2}$ and $\# 4$ employed HRIS to observe defects in this dwelling by producing thermograms and visual photographs of identical locations. However, they failed to recognize many uninsulated areas. Neither contractor inspected all of the walls, as they submitted only nine thermograms each, covering different areas of the house. There were also some questionable interpretations from the contractors. Both contractors observed the east wall of the living room and the southeast bedroom upstairs; and considered the 'cool' areas as voids. These areas are locations of the fireplace chimney, which are always cold except during use. Contractor 非 2 did identify this area as a fireplace chimney for the bedroom upstairs, without also considering the cold area in the living room, which is just behind the fireplace. NBS' interior and exterior thermograms gave a clear indication of the chimney location.

A detailed description of the defects observed by NBS as well as those by the IR contractors, is summarized in table Va. Besides the total defective wall area in $\mathrm{ft}^{2}$ found by each inspection, table Va also includes the defective wall areas in $\mathrm{ft}^{2}$ of each room of the house, analyzed from available thermograms and sketches. The total estimates of void areas is approximately $89 \mathrm{ft}^{2}$, which represents about 6 percent of the gross wall area. Table Vb presents the environmental conditions documented from each inspection. Thermograms 5-1 to 5-9 are some examples which demonstrate the locations of heat loss anomalies, as they are referred to in the descriptions in table $\mathrm{Va}$. 
Table Va. Summary of Defects Observed in MinneapolisSt. Paul House 非

Room \& Orientation

$$
\begin{gathered}
\text { Description of } \\
\text { Defects }
\end{gathered}
$$
Defective Observed by Wall NBS Contractors Area
非非 in $\mathrm{ft}^{2}$

2 Yes No No

Living

Room
E Small Voids Above Both Windows

Cold Air Penetration from Chimney of Fireplace; Infiltration Through Both Windows

S Voids Above Window and in 1 Upper Bay at SW of Window; Warm Area at SE Indicating Solar Loading; Alr Penetration Through Ceiling

Sma11 Voids Above Door

W Voids Above \& Below Window

$\begin{array}{ll}\text { Stairway W } & 1 \text { Partial Bay Cavity } \\ \text { (lst Floor) } & \text { at Side Door and } \\ & \text { Infiltration or } \\ & \text { Leakage Through Door }\end{array}$

Kitchen $W$ Voids Above Window and Pantry

Voids Below Pantry

1 Partial Bay Cavity at SW Corner

$N$ Voids Above Window and Behind Cabinets

Dining Room

\section{$\mathrm{N}$}

Voids Above Window and Partially in 1 Bay at NW of Window

Yes Yes Yes 5-1

6 Yes Yes No 5-2

Yes No No

4 Yes No No

3 Yes No No

8 Yes No Yes

Yes Yes No

Yes No No

6 Yes Yes No 5-3

6 Yes Yes Yes 5-4 
Table Va. Summary of Defects Observed in MinneapolisSt. Paul House 非 1

\begin{tabular}{|c|c|c|c|c|c|c|}
\hline $\begin{array}{l}\text { Room \& } \\
\text { Orientation }\end{array}$ & $\begin{array}{c}\text { Description of } \\
\text { Defects }\end{array}$ & $\begin{array}{c}\text { Defective } \\
\text { Wall } \\
\text { Area } \\
\text { in } \mathrm{ft}^{2}\end{array}$ & NBS & $\begin{array}{c}\text { Observed b } \\
\text { Contracto } \\
\text { 非 }\end{array}$ & $\begin{array}{l}\text { by } \\
\text { ors } \\
\text { \#4 }\end{array}$ & $\begin{array}{l}\text { Thermo- } \\
\text { gram } \\
\text { No. in } \\
\text { Append ix }\end{array}$ \\
\hline
\end{tabular}

Small Voids at NE Corner

Air Infiltration Around \& Below Window

E Voids Above SE Corner of Window and 1 Partial Bay Cavity at SE Corner

Stairway $W$ Voids Above Window (2nd Floor) and Infiltration at Celling

Bathroom $W$ Voids Above Window and Infiltration at NW Corner

$N$ Small Void and Infiltration Above Shower Area

Northroom $\mathrm{N}$

Voids Above Window

Northeast $\mathrm{N}$ Voids Above Window Bedroom

Partial Bay Cavities on Both Sides of Window

Shrinkage of Foam

E Voids Above Window and in Upper Part of Wall at SE of Window

Shrinkage of Foam at NE Side of Window and Infiltration at Ceiling-Wall Joint
Yes Yes No

Yes Yes No

8 Yes No No

4 Yes No Yes 5-5

3 Yes No Yes

1 Yes No No

4 No No Yes

4 Yes Yes Yes

Yes Yes No

Yes Yes Yes

4 Yes Yes No

Yes No No 5-6 
Table Va. Summary of Defects Observed in MinneapolisSt. Paul House 非 1

Roon \& Orientation

$$
\begin{gathered}
\text { Description of } \\
\text { Defects }
\end{gathered}
$$

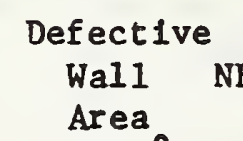

\begin{tabular}{|c|c|c|c|c|c|c|c|}
\hline $\begin{array}{l}\text { Southeast } \\
\text { Bedroom }\end{array}$ & $\mathrm{E}$ & $\begin{array}{l}\text { Cold Alr Penetration } \\
\text { at NE of Window } \\
\text { Through Fireplace } \\
\text { Chimney; Missing } \\
\text { Insulation at Both } \\
\text { Sides of Window }\end{array}$ & 8 & Yes & Yes & Yes & $5-7$ \\
\hline & S & $\begin{array}{l}\text { I Half Bay Cavity } \\
\text { at SE Corner } \\
\text { Voids Above Window } \\
\text { and in Partial Bays } \\
\text { at SW of Window; } \\
\text { Shrinkage of Foam }\end{array}$ & 10 & Yes & No & Yes & $5-8$ \\
\hline $\begin{array}{l}\text { Sout hwest } \\
\text { Bedroom }\end{array}$ & S & $\begin{array}{l}\text { Volds Above Window } \\
\text { and in } 2 \text { Upper Bays } \\
\text { at SE Corner; Some } \\
\text { Shrinkage of Foam }\end{array}$ & 3 & Yes & No & No & \\
\hline & W & $\begin{array}{l}\text { Voids in Upper } \\
\text { on Both Sides of } \\
\text { Windows }\end{array}$ & & Yes & No & No & $5-9$ \\
\hline $\begin{array}{l}\text { Total Wall } \\
\text { Insulatior } \\
\text { Given In }\end{array}$ & & $\begin{array}{l}\text { ea of } \\
\text { Ids Detected }\end{array}$ & 89 & 85 & 30 & 31 & \\
\hline
\end{tabular}


Table Vb. Environmental Conditions During Inspection of Minneapol1s-St. Paul House \#1

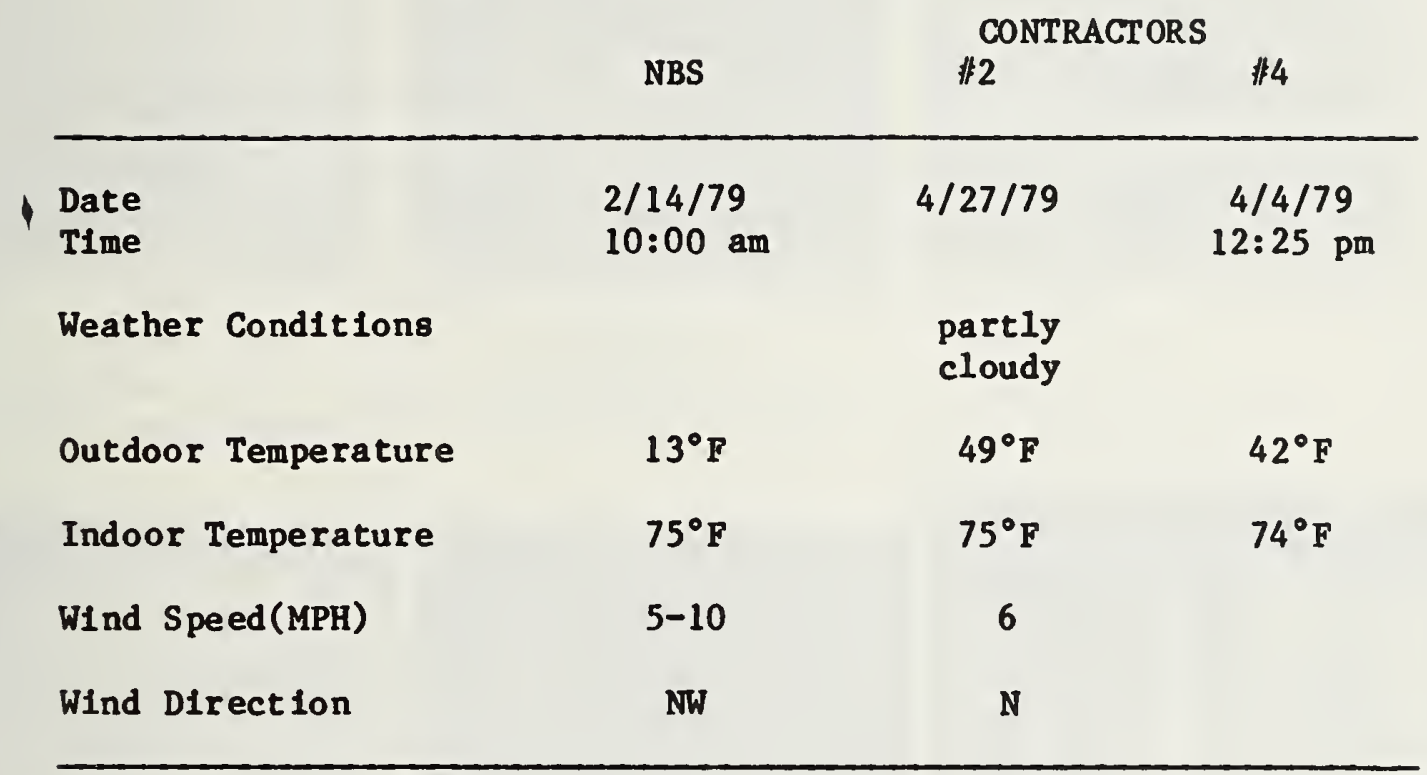



Thermal Anomalies Observed in Minneapolis-St. Paul House 非 1

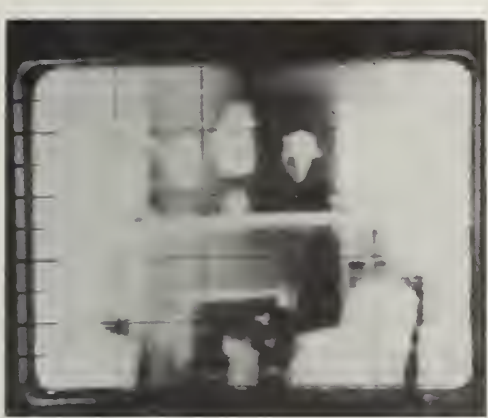

5-1

E wall of

living room.

(by contractor 非2)

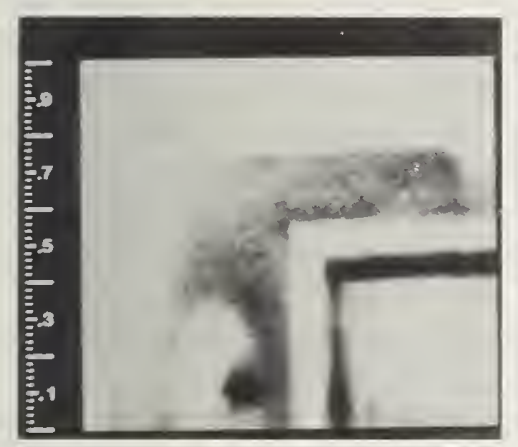

$$
\text { 5-4 }
$$

$\mathrm{N}$ wall of

dining room.

(by contractor 非)

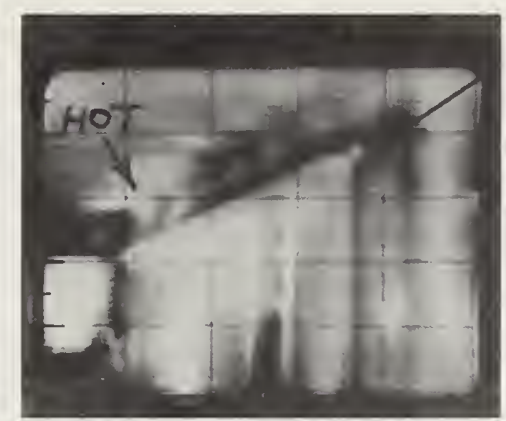

5-2

S wall of

living room.

(by contractor 非2)

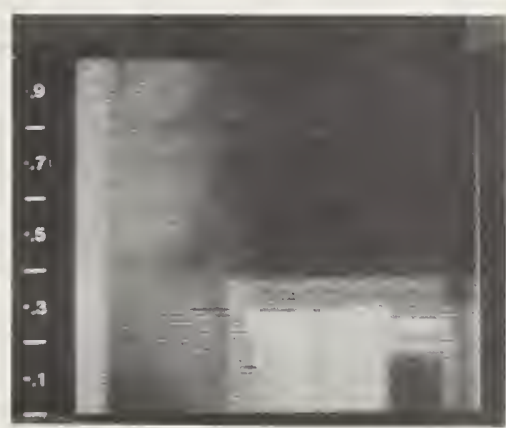

$$
\text { 5-5 }
$$

W of stairway

on 2nd floor.

(by NBS)

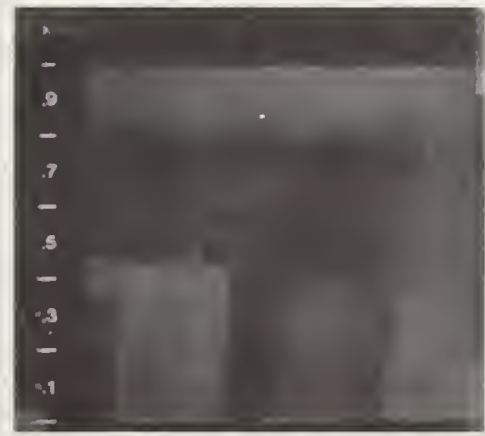

$$
5-8
$$

$S$ wall of

SE bedroom.

(by NBS)

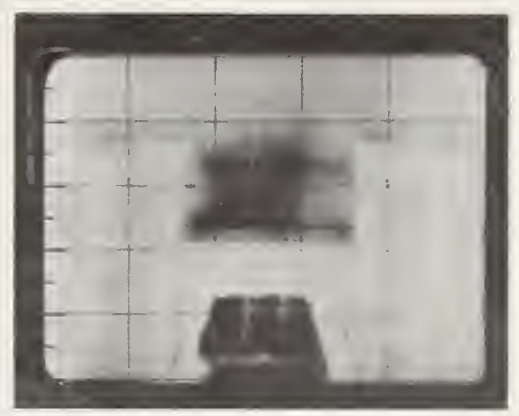

5-3

$\mathrm{N}$ wall of

kitchen.

(by contractor 非)

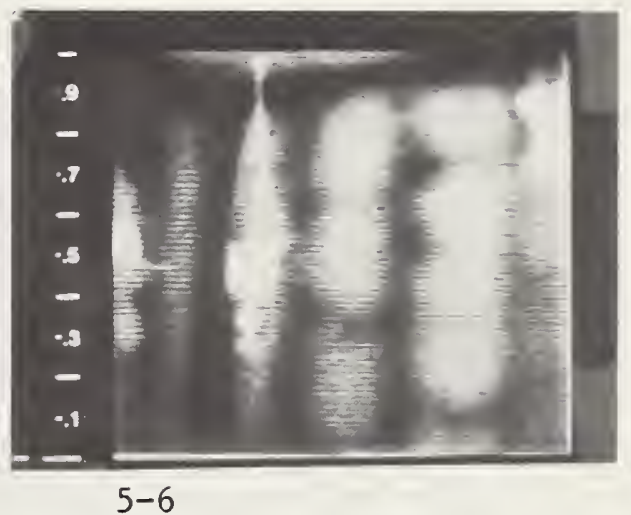

E wall of

$\mathrm{NE}$ bedroom.

(by NBS)
E wall of

SE bedroom.

(by NBS)

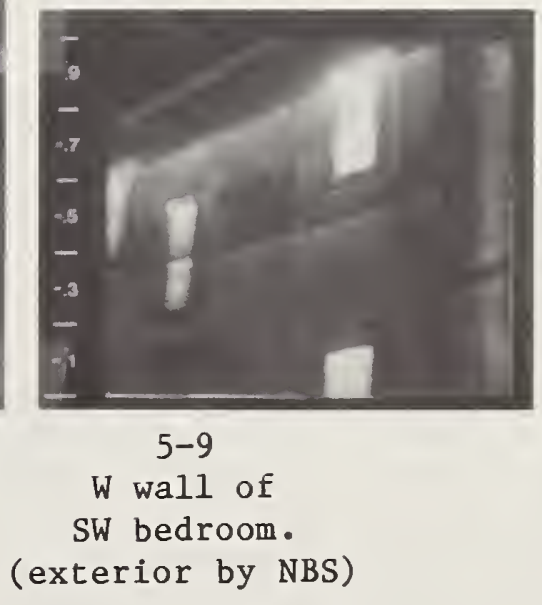



VI. Minneapolis-St. Paul House \#2

This is a two-story, approximately 80 year old residence whose interior dimensions are $45 \mathrm{ft}$. In length, $24 \mathrm{ft}$. In width, and $8 \mathrm{ft}$. In wall height on each floor; located in Minneapolis-St. Paul, MN. There are 9 rooms of living space, with an attic and a basement. Its exterior construction contains wood siding and an asphalt shingle roof.

Prior to the weatherization program, this house had no insulation. An insulation contractor was instructed to insulate this house with UF foam. After the retrofitted foam was injected into the walls this dwelling was inspected by NBS personnel and IR contractors 非, 非, and 非. A sketch of the voids and the locations of heat loss obtained from thermograms and documents by NBS as well as those by the IR contractors, is shown in figures VIa and VIb.

In general, the insulation on the first floor of this house is better than that on the second floor. Furthermore, all doors were found to be uninsulated and voids were observed at stairwells and cellings. On the first floor, many void areas were found in the living room, family room, dining room, and kitchen. On the second floor, pitched ceilings were found to be uninsulated, many walls have voids, windows have volds above them, and air was leaking from joints of pitched ceilings and walls.

Thermographic inspection by NBS identified most of the defects, except for those in the wall area underneath the uninsulated pitched ceiling at north of the west bedroom upstairs. Besides the interior inspection, NBS made a fairly complete exterior thermographic survey of this dwelling and observed most of the volds. There were some locations where only exterior thermograms were taken, such as the east wall on the left side of the window in the family room and above the north door of the dining room. The results of the NBS survey were used as a baseline for comparison purposes.

This is the only house in Minneapolis-St. Paul that was inspected by all three contractors, two contractors (\#2 and \#4) used HRIS to produce thermograms and one (非) used LRIS to sketch locations of missing locations. Contractors 非 and 4 produced 26 and 27 thermograms respectively and gave detalled locations of each wal1. Even though they missed some defects during inspection, their results are considered to be fairly good. Contractor 非 1 provided 16 sketches of which some did not show uninsulated areas. Hence its performance was not as good as that of the other contractors.

A detailed description of the defects observed by NBS, as well as IR those by the contractors, is summarized in table VIa. Besides the total defective wall area in $\mathrm{ft}^{2}$ found by each inspection, table VIa also includes the defective wall areas in $\mathrm{ft}^{2}$ of each room of the house, analyzed from avallable thermograms and sketches. The total estimates of vold areas is approximately $174 \mathrm{ft}^{2}$, which represents about 10 percent of the gross wall area. Table VIb presents the environmental conditions documented from each inspection. Thermograms/sketches 6-1 to 6-17 are some examples which demonstrate the locations of heat loss anomalies, as they are referred to in the descriptions in table VIa. 
Table VIa. Summary of Defects Observed in MinneapolisSt. Paul House \#2

\begin{tabular}{|c|c|c|c|c|c|}
\hline Room \& & Description of & Defective & Obs & erved by & Thermo- \\
\hline Orientation & Defects & $\begin{array}{c}\text { Wall } \\
\text { Area } \\
\text { in } f t^{2}\end{array}$ & NBS & $\begin{array}{l}\text { Contractors } \\
\text { \#1 } \$ 2 \quad \text { \#4 }\end{array}$ & $\begin{array}{l}\text { gram } \\
\text { No. In } \\
\text { Appendix }\end{array}$ \\
\hline
\end{tabular}

\begin{tabular}{|c|c|c|c|c|c|c|c|c|}
\hline Kitchen & W & $\begin{array}{l}\text { Voids Above Window } \\
\text { and in Several } \\
\text { Upper Bays Air } \\
\text { Infiltration From } \\
\text { Ceiling }\end{array}$ & 10 & Yes & Yes & Yes & Yes & $6-1$ \\
\hline & $\mathbf{N}$ & $\begin{array}{l}\text { Voids Above } \\
\text { Refrigerator \& Above } \\
\text { Door; Air Leakage } \\
\text { Around the Door }\end{array}$ & 5 & Yes & Yes & Yes & Yes & $6-2$ \\
\hline & E & $\begin{array}{l}\text { Voids Above Window } \\
\text { And in Lower Bays } \\
\text { at SE of Window } \\
\text { Voids Below Cabinets } \\
\text { and Infiltration } \\
\text { Around Window }\end{array}$ & 10 & Yes & Yes & No & No & \\
\hline Fanily & E & Voids Above Window & 13 & Yes & No & No & Yes & \\
\hline & & $\begin{array}{l}\text { Volds at Upper Part } \\
\text { of Whole Wall } \\
\text { Air Infiltration } \\
\text { From Floor }\end{array}$ & & Yes & No & No & No & $6-3$ \\
\hline $\begin{array}{l}\text { Living } \\
\text { Room }\end{array}$ & E & $\begin{array}{l}\text { Air Infiltration } \\
\text { or Leakage Around } \\
\text { Window }\end{array}$ & & Yes & Yes & No & No & \\
\hline & S & $\begin{array}{l}\text { Air Leakage Through } \\
\text { Door }\end{array}$ & 10 & Yes & Yes & No & No & \\
\hline & & $\begin{array}{l}\text { Voids Above Window } \\
\text { and in Several Bays } \\
\text { Partially at SE of } \\
\text { Window }\end{array}$ & & Yes & Yes & Yes & Yes & $6-4$ \\
\hline & & $\begin{array}{l}\text { Small Void Below } \\
\text { Window \& Infiltration } \\
\text { Around Window; Uneven } \\
\text { Application of Foam }\end{array}$ & & Yes & Yes & Yes & No & \\
\hline
\end{tabular}


Table VIa. Summary of Defects Observed in MinneapolisSt. Paul House \#2

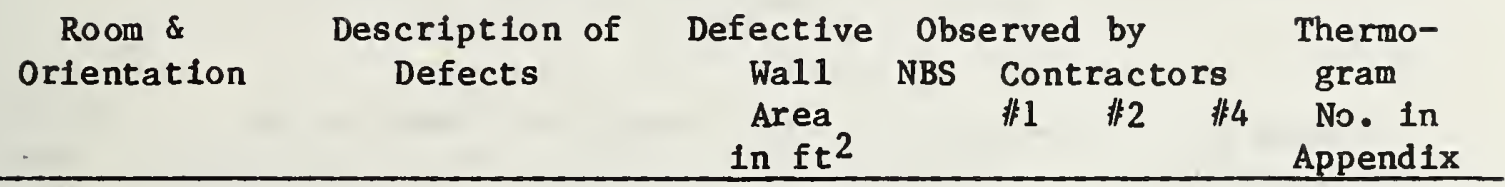

W No Defects Yes Yes No No

\begin{tabular}{|c|c|c|c|c|c|c|c|c|}
\hline \multirow[t]{6}{*}{$\begin{array}{l}\text { Dining } \\
\text { Room }\end{array}$} & W & $\begin{array}{l}\text { Voids Above Window } \\
\text { and in } 2 \text { Bays } \\
\text { Partially at SW of } \\
\text { Window }\end{array}$ & 18 & Yes & Yes & Yes & Yes & $6-5$ \\
\hline & & $\begin{array}{l}\text { Insulation Shrinkage } \\
\text { and Fissure in } \\
\text { Several Bays at NW } \\
\text { of Window }\end{array}$ & & Yes & Yes & Yes & No & $6-6$ \\
\hline & \multirow[t]{4}{*}{$\mathbf{N}$} & $\begin{array}{l}\text { Sma11 Volds Above } \\
\text { Door }\end{array}$ & 9 & Yes & No & No & No & $6-7$ \\
\hline & & $\begin{array}{l}\text { Air Leakage Through } \\
\text { Door }\end{array}$ & & Yes & No & Yes & Yes & \\
\hline & & $\begin{array}{l}\text { Missing Insulation } \\
\text { in } 1 \text { Lower Bay in } \\
\text { stairwell }\end{array}$ & & Yes & Yes & Yes & Yes & \\
\hline & & $\begin{array}{l}\text { Missing Insulation at } \\
\text { Ceiling of Stairway }\end{array}$ & & Yes & Yes & Yes & No & \\
\hline \multirow[t]{4}{*}{$\begin{array}{l}\text { North } \\
\text { Bedroom }\end{array}$} & W & $\begin{array}{l}\text { Uninsulated Pitched } \\
\text { Ceiling }\end{array}$ & 6 & Yes & No & Yes & Yes & $6-8$ \\
\hline & & $\begin{array}{l}\text { Voids Above Window } \\
\text { and in lst Bay at } \\
\text { NE and NW Corners } \\
\text { Partially }\end{array}$ & & Yes & No & Yes & No & $6-1$ \\
\hline & $\mathbf{N}$ & $\begin{array}{l}\text { Voids Below Pitched } \\
\text { Ceiling and above } \\
\text { Window }\end{array}$ & 10 & Yes & Yes & Yes & Yes & $6-2$ \\
\hline & & $\begin{array}{l}\text { Voids in 1st Bay } \\
\text { Cavities at NE and } \\
\text { NW Corners }\end{array}$ & & Yes & No & Yes & Yes & \\
\hline
\end{tabular}


Table VIa. Summary of Defects Observed In MinneapolisSt. Paul House \#2

Room \& orientation

$$
\text { Description of }
$$
Defects

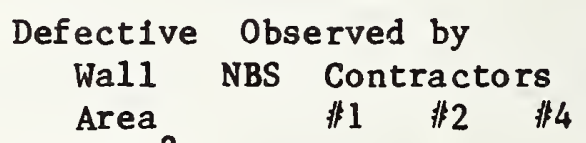

E Volds Above Window and in Half Bay Cavity at NE of Wind ow

Uninsulated Pitched Celling With Air Penetration Through Ceiling

Bathroom E Missing Insulation in the Upper Part of the Wall

25 Yes Yes Yes Yes

6-9

6-10

6-3

S Air Leakage at Celling-Wa11 Joint Under Pitched Ceiling

Sewing Room

E Missing Insulation Above Window at SE Corner

$S$ Voids Above Window and at $S E$ of Window Under Ceiling

South Bedroom

S Uninsulated Bay Cavities in the Upper Part of the Entire Wall

Alr Infiltration Below SE Window

W Uninsulated Pitched Ceiling and Air Leakage Underneath Small Voids Above Wind ow
7 Yes Yes No Yes 6-11 6-12

8 Yes Yes Yes Yes

20 Yes Yes Yes Yes 6-13

Yes Yes Yes Yes

1 Yes Yes Yes Yes 6-14 
Table VIa. Summary of Defects Observed in MinneapolisSt. Paul House 非

\begin{tabular}{|c|c|c|c|c|c|c|}
\hline $\begin{array}{c}\text { Room \& } \\
\text { Orientation }\end{array}$ & $\begin{array}{c}\text { Description of } \\
\text { Defects }\end{array}$ & $\begin{array}{c}\text { Defective } \\
\text { Wall }\end{array}$ & $\begin{array}{l}\text { Obs } \\
\text { NBS }\end{array}$ & $\begin{array}{l}\text { rved by } \\
\text { Contrac }\end{array}$ & & $\begin{array}{l}\text { Thermo- } \\
\text { gram }\end{array}$ \\
\hline & & $\begin{array}{c}\text { Area } \\
\text { in } \mathrm{ft}^{2}\end{array}$ & & 非 非 & 非4 & $\begin{array}{l}\text { No. in } \\
\text { Appendix }\end{array}$ \\
\hline
\end{tabular}

$\begin{array}{lllllll}\begin{array}{l}\text { West } \\ \text { Bedroom }\end{array} & \text { W } \begin{array}{l}\text { Voids Above Window } \\ \text { \& Under the Ceiling } \\ \text { at NW and SW Corners }\end{array} & 10 & \text { Yes Yes Yes Yes 6-15 } \\ \text { N } \begin{array}{l}\text { Uninsulated Pitched } \\ \text { Ceiling and Wall } \\ \text { Area Underneath }\end{array} & 5 \text { No No Yes No 6-16 } \\ \text { S Uninsulated Pitched } & \text { No No Yes Yes } \\ \text { Ceiling } & & \end{array}$

Total Area of

Insulation Voids

$\begin{array}{lllll}174 & 169 & 125 & 142 & 144\end{array}$

in $\mathrm{ft}^{2}$

Table VIb. Environmental Conditions During Inspection of Minneapolis-St. Paul House \#2

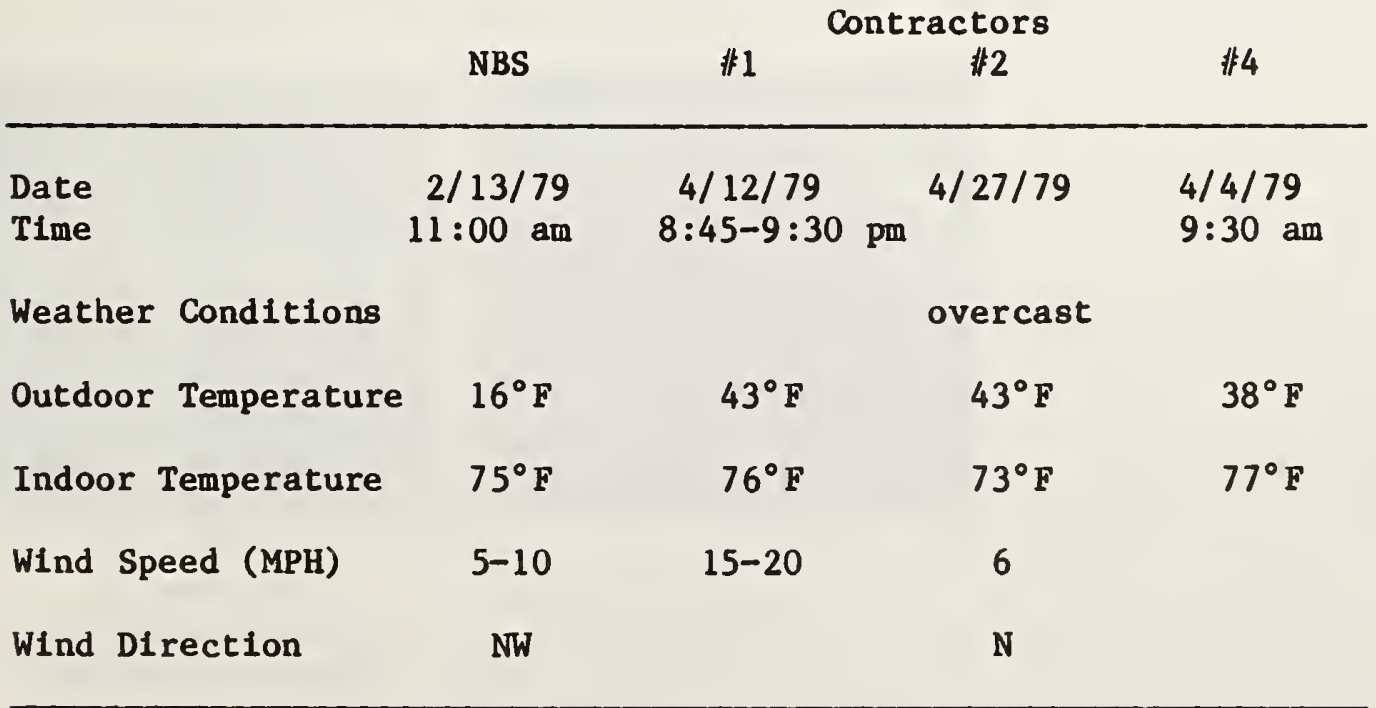



Thermal Anomalies Observed in Minneapolis-St. Paul House 非

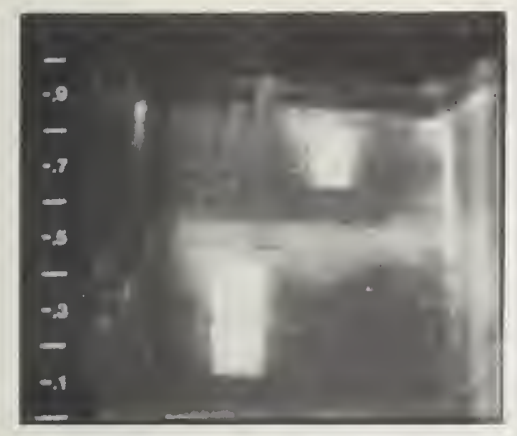

6-1

$W$ side of kitchen $\& \mathrm{~N}$ bedroom. (exterior by NBS)

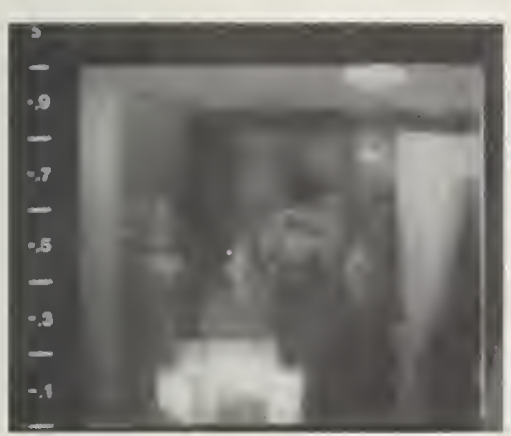

$$
6-4
$$

S wall of

living room.

(by NBS)

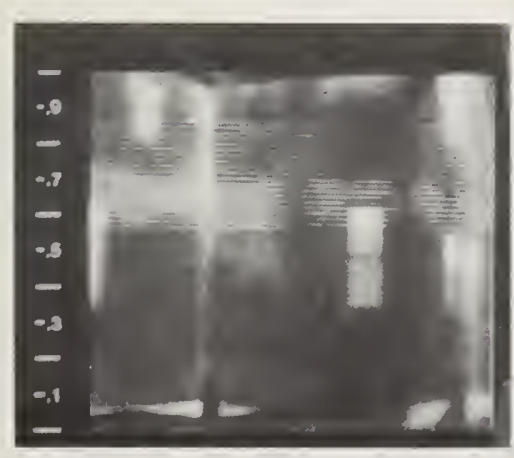

6-7

$\mathrm{N}$ side of

dining room.

(exterior by NBS)

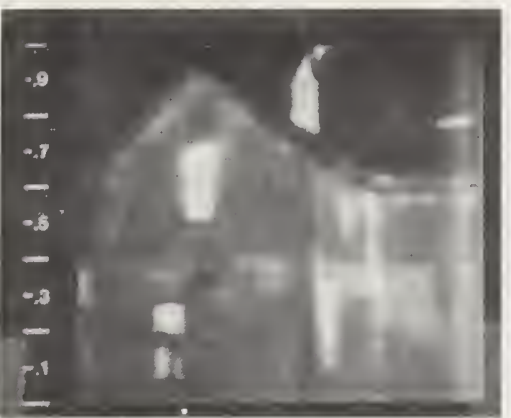

6-2

$\mathrm{N}$ side of kitchen $\& N$ bedroom. (exterior by NBS)

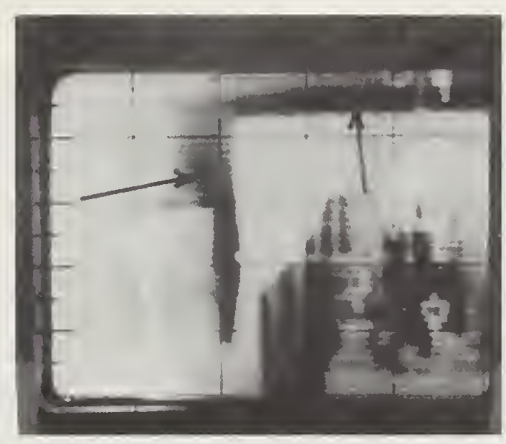

6-5

SW corner on $W$ of dining room.

(by contractor 非)

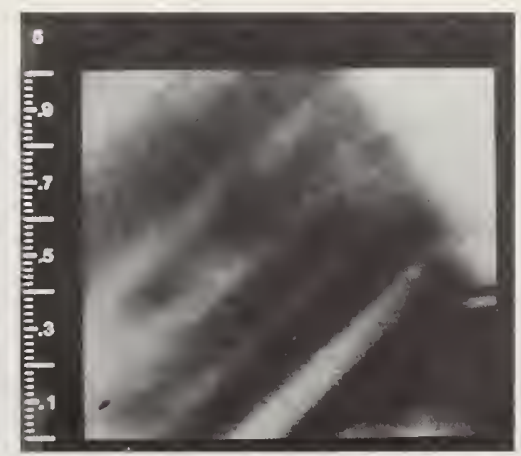

6-8

$W$ pitched ceiling of $\mathrm{N}$ bedroom.

(by contractor \#4)

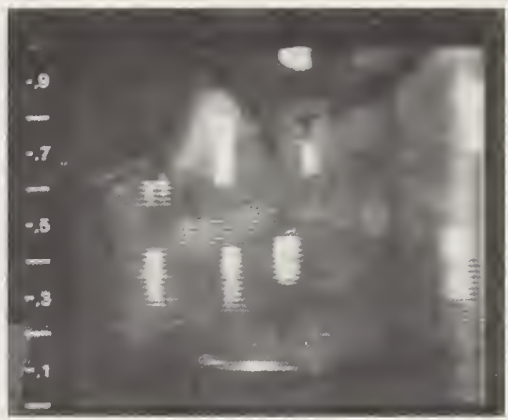

6-3

E side of family room \& bathroom. (exterior by NBS)

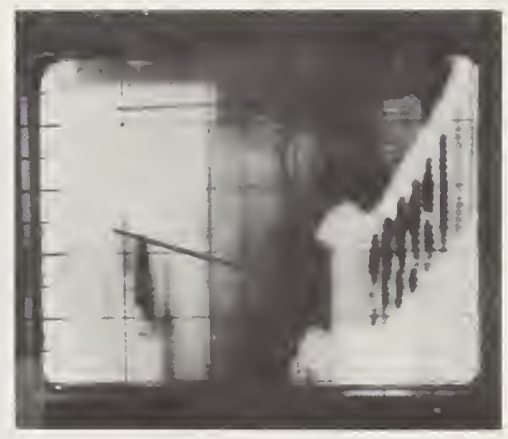

$$
\text { 6-6 }
$$

NW corner on $W$

of dining room.

(by contractor \#2)

$$
A-32
$$





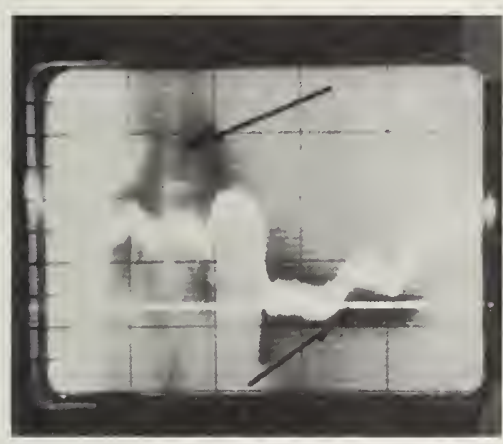

$$
\text { 6-9 }
$$

NE corner on $\mathrm{E}$ of bathroom.

(by contractor 非)

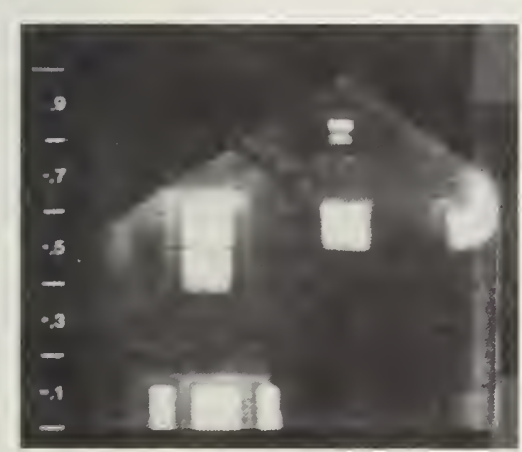

$$
6-12
$$

$\mathrm{S}$ side of sewing room \& $S$ bedroom. (exterior by NBS)

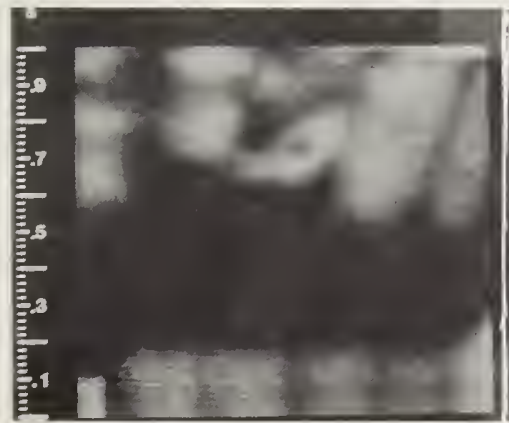

$$
\text { 6-14 }
$$

W pitched ceiling of $\mathrm{S}$ bedroom.

(by contractor 非4)

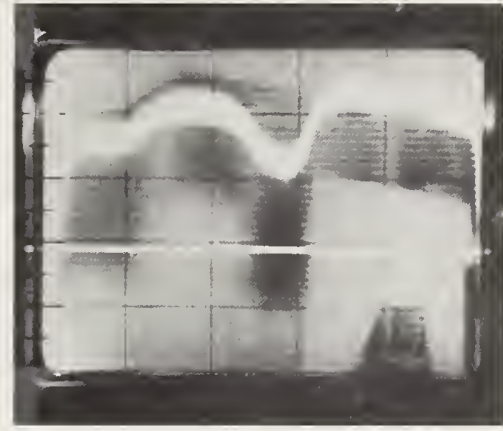

$$
6-10
$$

SE corner on $\mathrm{E}$

of bathroom. (by contractor 非)

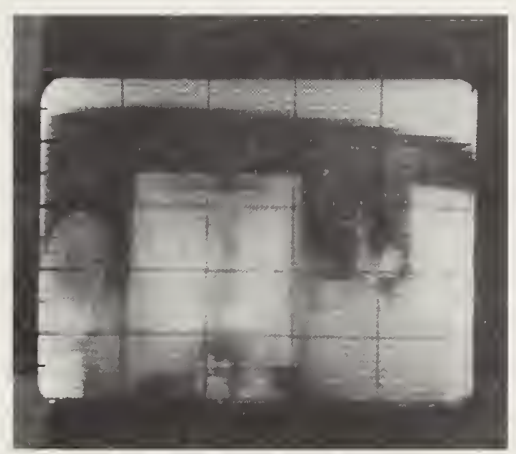

\section{6-13}

$S$ wall of

$S$ bedroom.

(by contractor 非2)

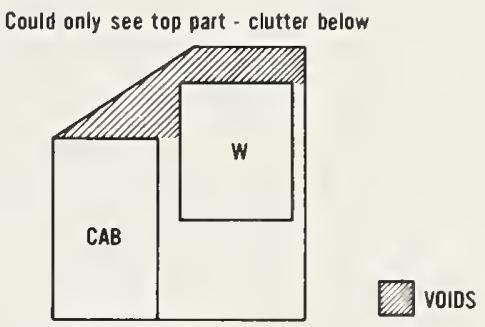

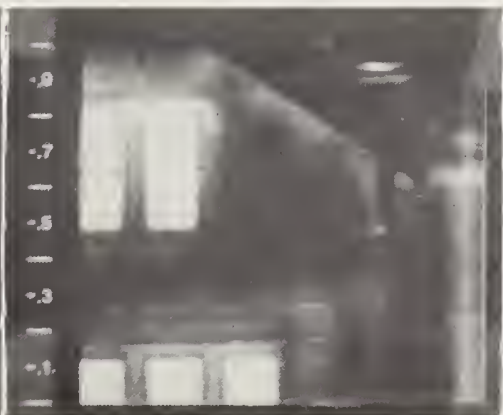

6-15

$W$ side of $W$ bedroom. (exterior by NBS)

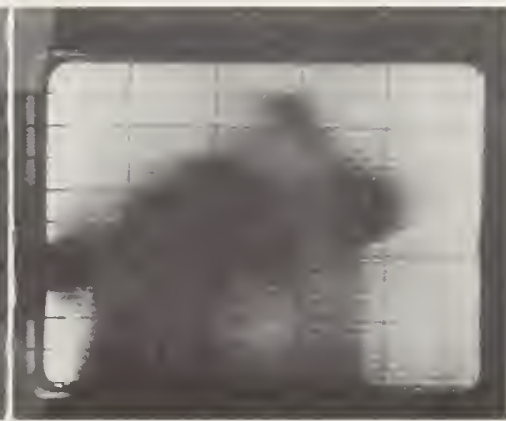

6-16

$N$ pitched ceiling of $\mathrm{W}$ bedroom. (by contractor 非) 

VII. Minneapolis-St. Paul House $\vDash 3$

This is a two-story, approximately 45 year old residence whose interior dimensions are $36 \mathrm{ft}$. In length, $24 \mathrm{ft}$. In width, and $8 \mathrm{ft}$. in wall height on each floor; located in Minneapolis-St. Paul, MN. There are 7 rooms of living space, with an attic and a basement. Its exterior construction contains wood frame with steel siding and an asphalt shingle roof.

Prior to the weatherization program, this house had no insulation. An insulation contractor was instructed to insulate the walls of this house with UF foam. After retrofitted foam was injected to the walls, this dwelling was inspected by NBS personnel and IR contractors 11 , and $\#_{4}$. A sketch of the vo1ds and the locations of heat loss obtained from thermograms and documents by NBS as well as those by the IR contractors, is shown in figures VIIa and VIIb.

The quality of the insulation job for this dwelling is questionable since there are about 15 whole bay cavities, 25 half bay cavities, and 17 one third bay cavities still without insulation in the house. The overall defects of this dwelling were found to be worse on the west and the north sides; with volds in the walls, and air penetration under the ceiling insulation. The east side was found to have missed insulation in about half of the walls on the second floor, with air penetration at the joint under the pitched ceiling. The first floor exhibited voids around windows and doors. The south side was shown to have one bay cavity and a few small voids on the second floor.

Thermographic inspection by NBS observed most of the known defects of this residence so that its results were used as a baseline for comparison purposes. In addition, NBS depicted the celling defects of the den/kitchen, showing some cold spots that may be damaged by moisture from condensation or a leaking roof.

Contractor 非 1 conducted a rather complete inspection of this house, missing only a few voids, while contractor \#2 falled to observe several voids, as it produced only seven thermograms. The quality of these thermograms was quite poor and the area of scanning was often incomplete.

A detailed description of the defects observed by NBS as well as those by the IR contractors is summarized in table VIIa. Besides the total defective wall area in $\mathrm{ft}^{2}$ found by each inspection, table VIIa also includes the defective wall areas in $\mathrm{ft}^{2}$ of each room of the house, analyzed from available thermograms and sketches. The total estimates of vold areas is approximately $310 \mathrm{ft}^{2}$, which represents about 20 percent of the gross wall area. Table VIIb presents the environmental conditions documented from each inspection. Thermograms/sketches 7-1 to 7-11 are some examples which demonstrate the locations of heat loss anomalies, as they are referred to in the descriptions in table VIIa. 
Table VIIa. Summary of Defects Observed in MinneapolisSt. Paul House \#3

Room \& orientation

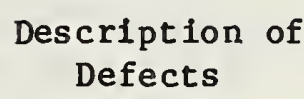

\section{Defective \\ Wall \\ Area}

in $f t^{2}$

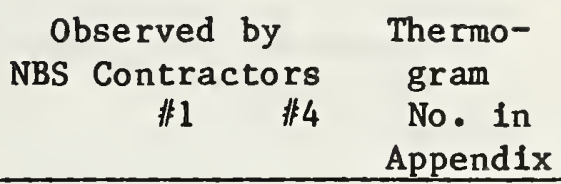

\section{Living} Room

Dining Room

Den \& K1tchen
$S$ Voids Above Window, Voids Above Door \& in 1 Upper Bay Between Window and Door

W Voids Above Window And in 1 Bay Cavity at NW of Window; Foam Shrinkage or Voids on Both Sides of Window

W Partial Voids Above Window and in Bay Cavities at Both Sides of Window, Missing Insulation in the Upper Part of the Entire Wall

N Partial Voids Above Window and in Bay Cavities on Both Sides of Window

Missing Insulation at the NW Side of Window

W Air Penetration from Ceiling

Foam Shrinkage or Voids in Upper Bays Partially

N Volds Above Window and in Upper Bay Cavity at NW Corner
10 Yes Yes Yes

30 Yes Yes Yes 7-1

$7-2$

35 Yes Yes No

Yes Yes Yes

5 Yes No No 7-4

Yes No No 7-5

13 Yes No No 7-6 
Table VIIa. Summary of Defects Observed in MinneapolisSt. Paul House 非

Room \& Orientation
Description of Defects
Defective
Wall
Area
in $f t^{2}$
Observed by
tractors

Thermo-

gram

No. in

Append $1 x$

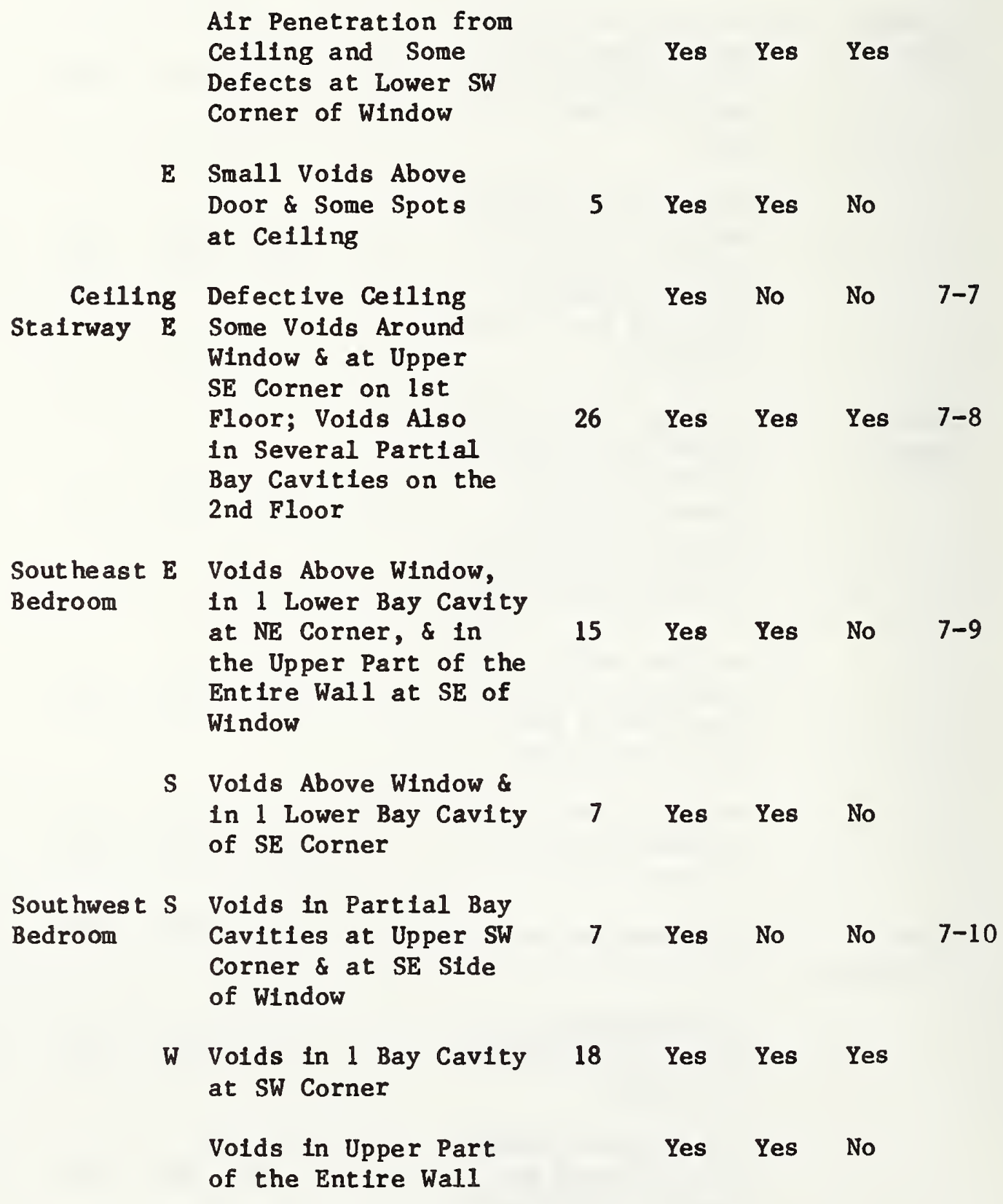


Table VIIa. Summary of Defects Observed In MinneapolisSt. Paul House 非

Room \&
Orientation
Description of Defective Observed by Defects .. Wall NBS Contractors

ThermoArea 非 \#4 No. in in $\mathrm{ft}^{2}$

Append ix

\begin{tabular}{|c|c|c|c|c|c|c|}
\hline $\begin{array}{l}\text { Northwest } \\
\text { Bedroom }\end{array}$ & W & $\begin{array}{l}\text { Voids in } 1 \text { Bay Cavity } \\
\text { at SW Side of Window } \\
\text { and in the Upper Part } \\
\text { of the Entire Wall }\end{array}$ & 30 & Yes & Yes & Yes \\
\hline & $\mathbf{N}$ & $\begin{array}{l}\text { Volds in } 1 \text { Bay Cavity } \\
\text { at NW of Window \& in } \\
\text { the Upper Part of the } \\
\text { Entire Wall }\end{array}$ & 26 & Yes & Yes & No \\
\hline Bathroom & $\mathbf{N}$ & $\begin{array}{l}\text { Uninsulated Upper } \\
\text { Part of the Entire } \\
\text { Wall }\end{array}$ & 20 & Yes & Yes & No \\
\hline & & $\begin{array}{l}\text { Voids at Celling- } \\
\text { Wall Joint with Air } \\
\text { Penetration from the } \\
\text { Ceiling }\end{array}$ & & Yes & Yes & Yes \\
\hline & $E$ & $\begin{array}{l}\text { Voids Above Window } \\
\text { and in Several Upper } \\
\text { Bay Cavities }\end{array}$ & 25 & Yes & Cool & No \\
\hline & $S$ & $\begin{array}{l}\text { Voids Suspected in } \\
\text { Partition Wall }\end{array}$ & & Yes & No & No \\
\hline $\begin{array}{l}\text { Total Wal } \\
\text { Insulatio } \\
\text { Given in }\end{array}$ & & $\begin{array}{l}\text { Ids Detected } \\
\text { Ids Dete }\end{array}$ & 310 & 310 & 277 & 118 \\
\hline
\end{tabular}


Table VIIb. Environmental Conditions During Inspection of Minneapolis-St. Paul House \#3

\begin{tabular}{lccc} 
& & Contractors & $\# 4$ \\
& NBS & $\$ 1$ & $4 / 4 / 79$ \\
Date & $2 / 14 / 79$ & $4 / 11 / 79$ & $11: 00$ am \\
Time & $5: 00 \mathrm{pm}$ & $7: 30-8: 45 \mathrm{pm}$ & $43^{\circ} \mathrm{F}$ \\
Outdoor Temperature & $10^{\circ} \mathrm{F}$ & $39^{\circ} \mathrm{F}$ & $78^{\circ} \mathrm{F}$ \\
Indoor Temperature & $75^{\circ} \mathrm{F}$ & $75^{\circ} \mathrm{F}$ & \\
Wind Speed(MPH) & $5-10$ & $30+$ & \\
Wind Direction & $\mathrm{NW}$ & & \\
\hline
\end{tabular}




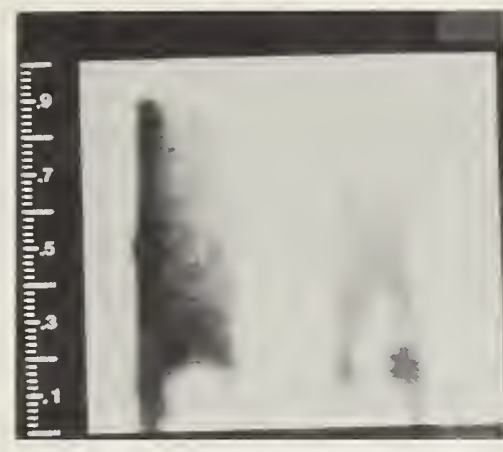

7-1

SW on $W$ of

living room.

(by contractor 非)

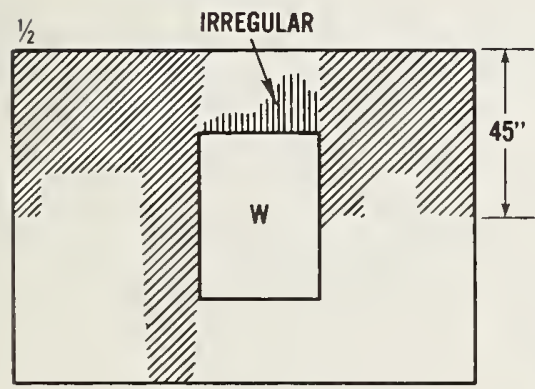

$$
7-3
$$

W wall of

dining room.

(by LRIS)

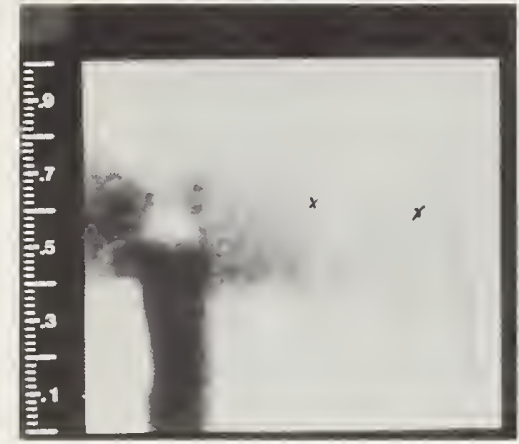

7-2

$\mathrm{NW}$ on $\mathrm{W}$ of

living room.

(by contractor 非)

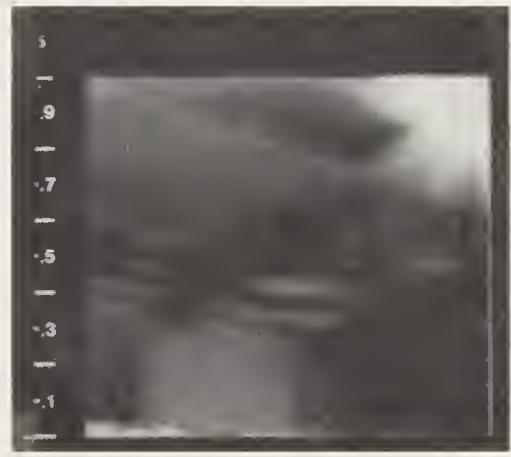

7-4

Ceiling on $\mathrm{W}$ of den/kitchen.

(by NBS)

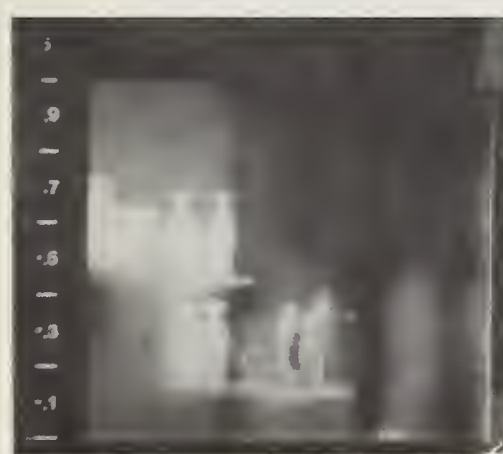

7-5

W wall of den/kitchen.

(by NBS)

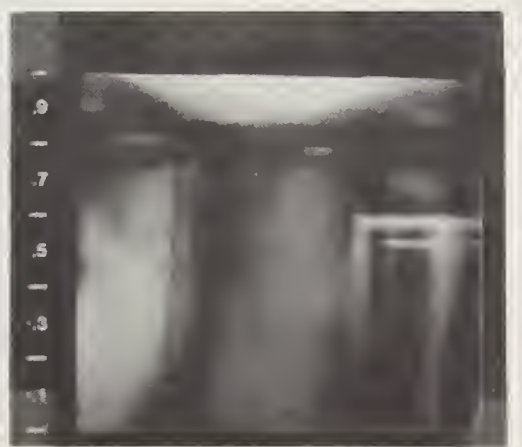

7-6

$\mathrm{N}$ wal1 of den/kitchen

(by NBS)

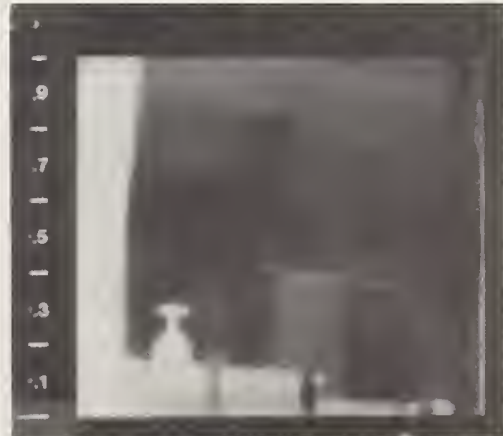

7-7

Ceiling of $\mathrm{den} / \mathrm{kitchen}$

(by NBS)

$$
\text { A-39 }
$$



Thermal Anomalies Observed in Minneapolis-St. Pau1 House \#3 (continued)
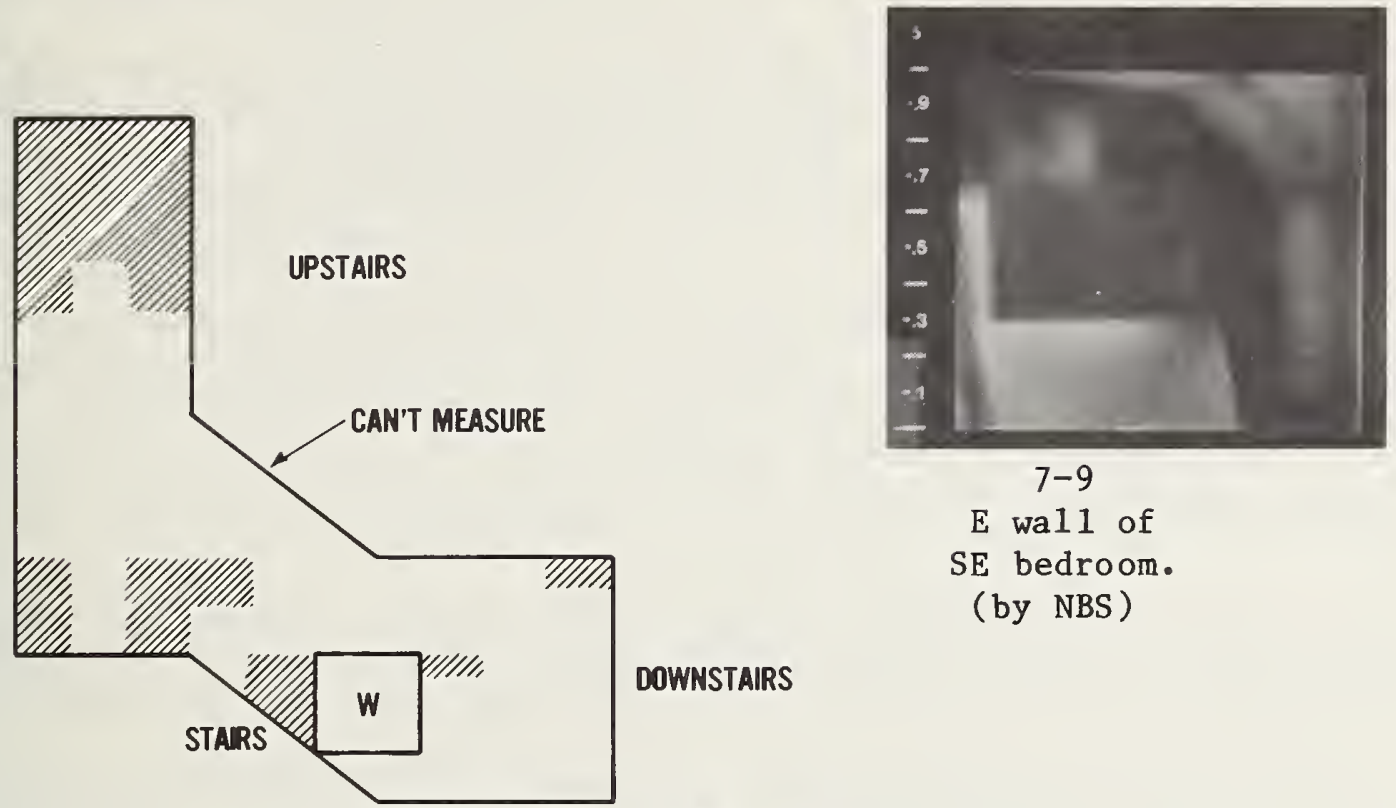

7-9

E wal1 of

SE bedroom.

(by NBS)

\section{DOWNSTAIRS}

Moids

$$
7-8
$$

W wa11 of stairway .

(by LRIS)
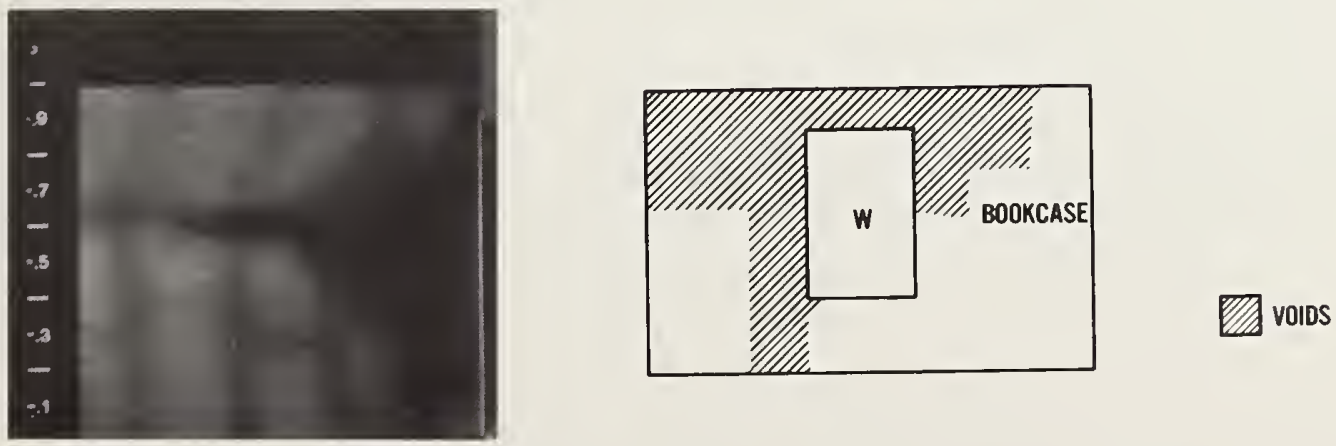

7-10

SW corner of

SW bedroom.

(by NBS)

7-11

N wall of NW bedroom.

(by LRIS) 

VIII. Minneapolis-St. Paul House 非

This is a two-story, approximately 50 year old residence whose interior dimensions are $42 \mathrm{ft}$. in length, $30 \mathrm{ft}$. in width, and $8 \mathrm{ft}$. in wall height on each floor; located in Minneapolis-St. Paul, MN. There are 7 rooms of living space, with an attic and a basement. Its exterior construction contains wood siding and an asphalt shingle roof.

Prior to the weatherization program, this house had no insulation. An insulation contractor was instructed to insulate the walls of this house with UF foam. After retrofitted foam was injected into the walls, this dwelling was inspected by NBS personnel and IR contractors 1 , and 非. A sketch of the voids and the location of heat loss obtained from thermograms and documents by NBS, as well as those by the IR contractors, is shown in figures VIIIa and VIIIb.

In general, the insulation job for this dwelling was considered to be fairly good except for both the north side and the east wall of the northeast bedroom on the second floor, and the west wall of the living room on the first floor.

Thermographic inspection by NBS located most known defects of this residence so that its results were used as a baseline for comparison purposes.

Contractor 非 4 submitted only four thermograms of the living room and the north wall of the northeast bedroom. On the other hand, contractor 非 seemed to inspect every room of the house; but reported that many walls were satisfactory, and interpreted many low temperature regions as cool areas instead of defects. Therefore, the estimated number of voids from contractor 非's thermograms, and from contractor 非's sketches, were considered to be low.

A detailed description of the defects observed by NBS as well as those by the IR contractors, is summarized in table VIIIa. Beside the total defective wall area in $\mathrm{ft}^{2}$ found by each inspection, table VIIIa also includes the defective wall areas in $\mathrm{ft}^{2}$ of each room of the house, analyzed from available thermograms and sketches. The total estimates of void areas is approximately $75 \mathrm{ft}^{2}$, which represents about 4 percent of the gross wall area. Table VIIIb presents the environmental conditions documented from each inspection. Thermograms/sketches 8-1 to 8-8 are some examples which demonstrate the locations of heat loss anomalies, as they are referred to in the descriptions in table VIIIa. 
Table VIIIa. Summary of Defects Observed In MinneapolisSt. Paul House 非 4

\begin{tabular}{|c|c|c|c|c|c|}
\hline Room \& & Description of & Defect Ive & & oserved by & The rmo- \\
\hline Orientation & Defects & $\begin{array}{c}\text { Wall } \\
\text { Area } \\
\text { In } \mathrm{ft}^{2}\end{array}$ & NBS & $\begin{array}{c}\text { Contractors } \\
\# 1\end{array}$ & $\begin{array}{l}\text { grams } \\
\text { No. in } \\
\text { Appendix }\end{array}$ \\
\hline
\end{tabular}

Kitchen $W$ Small Void at $\mathrm{N}$ of

Window and Air

3 Yes No Yes

Infiltration at $\mathrm{NW}$

Corner

N Small Volds Above

Window \& Door, Also

in Half Bay Cavity

at NE Corner

Dining $\quad \mathrm{N}$ Small Void Below

Room Window and at NW

Upper Corner Air

Infiltration Around

5 Yes No No

Window \& at NE Corner

E Voids Above Window \& Missing Insulation at Both Sides of Window

5 Yes No No

5 Tes No

Living

E Only Some Infiltration

Room

Underneath Window

S Some Volds Above Door

8 Yes Yes Yes

Partial Voids Above Window \& 1 Upper Bay

at SE Corner

Yes No Yes

W Voids Above Window and in Partial Bay Cavities at Both

16 Yes No No 8-1

Sides of Window

Stairway $W$ Voids Above Window

(2nd Floor) and in 1 Partial Bay

Cavity at $S$ of Window

6 Yes Yes No 8-5

8 Yes Yes No 8-3

$8-4$

Northwest $\mathrm{W}$ Small Void at NW

Bedroom

Corner Under Ceiling; Air Penetration From Ceiling, and Above \& Bel ow Window 
Table VIIIa. Summary of Defects Observed in MinneapolisSt. Paul House 非

\begin{tabular}{|c|c|c|c|c|c|}
\hline Room \& & Description of & Defective & & bserved by & The rmo- \\
\hline rientation & Defects & $\begin{array}{c}\text { Wall } \\
\text { Area } \\
\text { in } f t^{2}\end{array}$ & NBS & Contractors & $\begin{array}{c}\text { grams } \\
\text { No. in } \\
\text { Append } 1 x\end{array}$ \\
\hline
\end{tabular}

N Small Voids at NW and NE Corners; Air 4 Yes No No Penetration From Ceiling

Bathroom N Air Penetration at Top \& Around Window Yes No Yes

Northeast $\mathrm{N}$ Voids Above Window Bedroom and Across the Top at $\mathrm{E}$ Side of Window with Shrinkage of Insulation or Fissure; 10 Yes Yes Yes 8-7 Air Infiltration Around Window

E Voids Above Window and in Partial Bay Cavity at NE Corner

6 Yes No No

South

$S$ Voids in Partial Bay

2 Yes No No

Bedroom Cavity at SE Corner

Air Penetration at Floor \& Above Window

Yes No Yes

Total Wall Area of

$\begin{array}{llll}75 & 75 & 24 & 21\end{array}$

Insulation Voids Detected

Given in $\mathrm{ft}^{2}$ 
Table VIIIb. Environmental Conditions During Inspection of Minneapolis-St. Paul House \#4

\begin{tabular}{lccc} 
& NBS & Contractors & $\$ 4$ \\
\hline $\begin{array}{l}\text { Date } \\
\text { Time }\end{array}$ & $2 / 13 / 79$ & $4 / 12 / 79$ & $4 / 4 / 79$ \\
Outdoor Temperature & $3: 00 \mathrm{pm}$ & $7: 30-8: 15 \mathrm{pm}$ & $11: 55 \mathrm{am}$ \\
Indoor Temperature & $15^{\circ} \mathrm{F}$ & $44^{\circ} \mathrm{F}$ & $43^{\circ} \mathrm{F}$ \\
Wind Speed(MPH) & $75^{\circ} \mathrm{F}$ & $74^{\circ} \mathrm{F}$ & $75^{\circ} \mathrm{F}$ \\
Wind Direction & $5-10$ & 20 & \\
\hline
\end{tabular}


Thermal Anomalies Observed in Minneapolis-St. Pau1 House 非 4

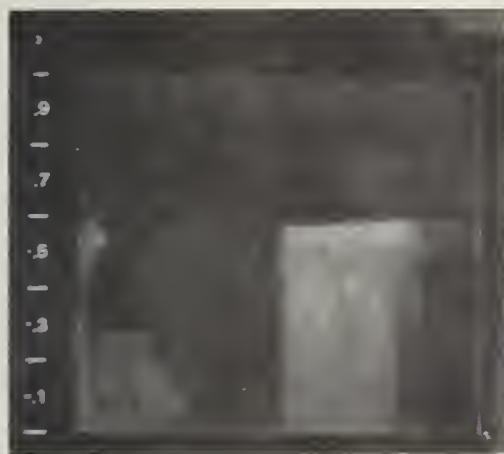

8-1

$\mathrm{NE}$ on $\mathrm{E}$ wall of dining room. (by NBS)

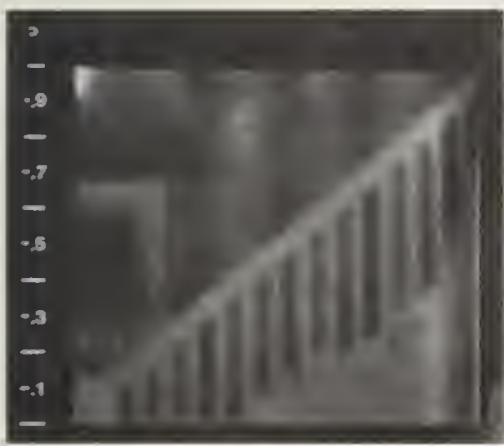

$8-4$

W wall \& stairway of living room. (by NBS)

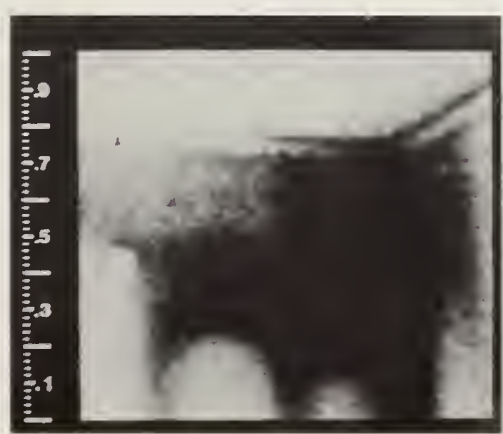

8-7

NE corner on $N$ of NE bedroom. (by contractor 非)

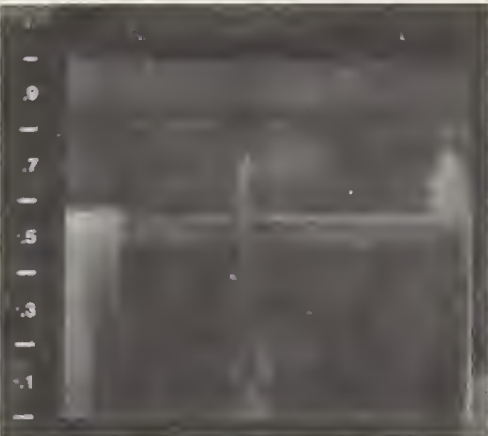

$$
\text { 8-2 }
$$

Above window on

$E$ wall of dining room (by NBS)

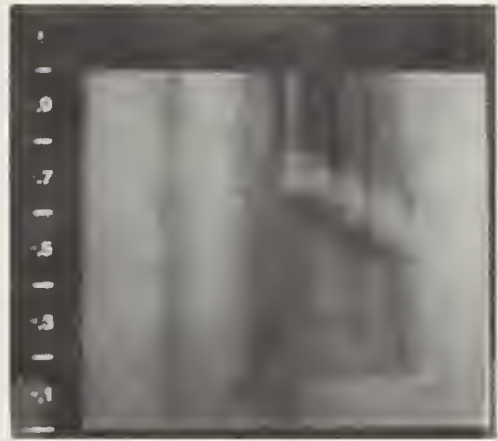

$$
\text { 8-5 }
$$

Below window on $W$ of stairway upstairs. (by NBS)

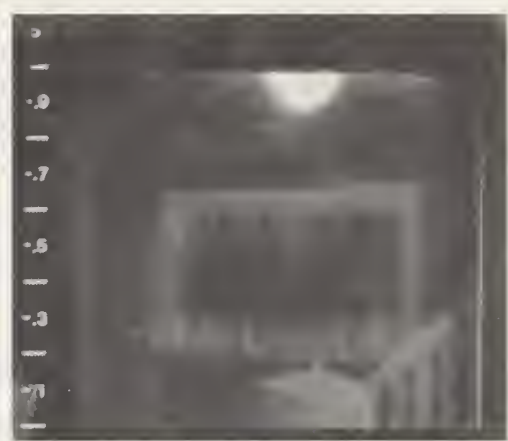

8-3

Above window \& at bottom of stairs on $W$ of living room.

(by NBS)

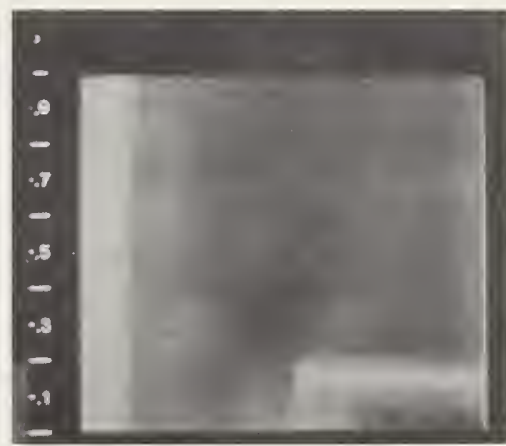

$$
\text { 8-6 }
$$

Above window on

$W$ of stairway upstairs. (by NBS)

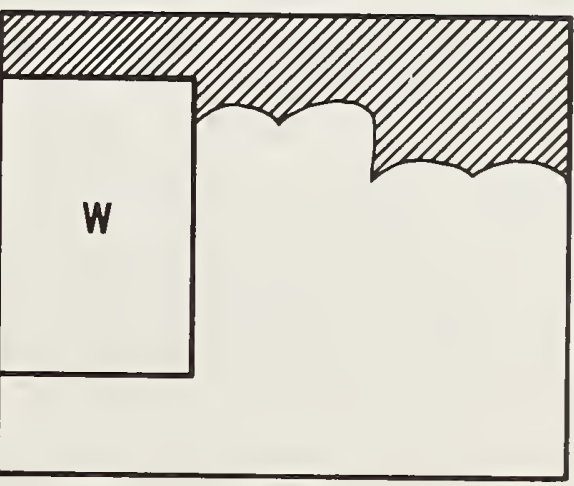

$$
\text { 8-8 }
$$

$E$ wall of NE bedroom.

(by LRIS)

\section{VOIDS}

$$
\text { A-45 }
$$



IX. Portland House 非 1

This is a two-story, approximately 23 year old residence whose interior dimensions are $32 \mathrm{ft}$. in length, $25 \mathrm{ft}$. in width, and $7 \mathrm{ft}$. in wall height on each floor; located in Portland, ME. There are 8 rooms of living space with an attic and a basement. Its exterior construction contains wood frame siding and an asphalt shingle roof.

Prior to the weatherization program, this house had no insulation. An insulation contractor was instructed to insulate the walls and attic with cellulose, and install storm windows and storm doors. After retrofitted options were completed this dwelling was inspected by NBS personnel and IR contractors 非, and 非6. A sketch of the voids and the locations of heat loss obtained from thermograms and documents by NBS, as well as those by the IR contractors, is shown in figures IXa and IXb.

In general, the most common heat loss areas in this house were found at at locations around most windows and above the windows upstairs. There are many ceiling areas with defects. At the bottom of the stairway, missed insulation was depicted at the upper right of the window and at the ceiling. Also the celling over the stairs, on the second floor showed an uneven temperature distribution at the surface, indicating defective insulation. Moreover, variable insulation at the pitched ceiling at the north side of the northeast bedroom is probably the result of the insulation not being installed at full density. The north wall of this room seemed to have air penetration as well.

Thermographic inspection by NBS observed most known defects of this residence so that its results were used as a baseline for comparison purposes.

Contractors $\left.\right|^{5}$ and 非 6 seemed to identify most of the defective areas of this dwelling, by submitting thermograms and/or statements.

A detailed description of the defects observed by NBS as well as those by the IR contractors, is summarized in table IXa. Besides the total defective wall area in $\mathrm{ft}^{2}$ found by each inspection, table IXa also included the defective wall areas in $\mathrm{ft}^{2}$ of each room of the house, analyzed from available thermograms and statements. The total estimates of void areas is approximately $106 \mathrm{ft}^{2}$, which represents about 8 percent of the gross wall area. Table IXb presents the environmental conditions documented from each inspection. Thermograms 9-1 to 9-13 are some examples which demonstrate the locations of heat loss anomalies, as they are referred to in the descriptions in table IXa. 

Table IXa. Summary of Defects Observed in Portland House \#1

\begin{tabular}{|c|c|c|c|c|c|c|}
\hline $\begin{array}{c}\text { Room \& } \\
\text { Orientation }\end{array}$ & $\begin{array}{c}\text { Description of } \\
\text { Defects }\end{array}$ & $\begin{array}{c}\text { Defect ive } \\
\text { Wall } \\
\text { Area } \\
\text { in } \mathrm{ft}^{2}\end{array}$ & $\begin{array}{r}01 \\
\text { NBS }\end{array}$ & $\begin{array}{c}\text { bse rved } \\
\text { Contrac } \\
\text { 非 }\end{array}$ & $\begin{array}{l}\text { by } \\
\text { tors } \\
\text { 非6 }\end{array}$ & $\begin{array}{l}\text { Thermo- } \\
\text { grams } \\
\text { No. in } \\
\text { Appendix }\end{array}$ \\
\hline
\end{tabular}

Kitche
Dining

Romm

Front $\quad S$ Voids Under Light

Entrance Switch at $W$ of Door;

Air Infiltration

Around Door and at

Both SE \& SW Corners

Living

Room

N Small Void Above $W$ Window; Air Leakage Under Windows

E Smal1 Void Between Door \& Cabinet; Air Leakage Around Door \& Below Cabinet

E Voids Above Window, Around Window, \& in 1 Partial Bay Cavity at NE Corner; Air Infiltration UnderNeath Window

$S$ Air Infiltration at Both SE \& SW Corners
14 Yes Yes Yes 9-1

Yes Yes Yes

4 Yes Yes No 9-2

Yes Yes No 9-4 be Outside Crack) Air
1 Yes Yes Yes

1 Yes Yes Yes

1 - Yes Yes Yes
Infiltration on $W$ of Window and at Both SE and SW Corners

W Voids in 1 Bay Cavity at SW Corner, 1 Bay Cavity at $S$ of $S W$ Window, Between SW \& Center Windows, and Partially Center \& NW 35 Yes Yes Yes 9-5 Windows; Air Leakage From Ceiling 
Table IXa. Summary of Defects Observed in Portland House \#1

Room \& Description of Defective Observed by ThermoOrientation Defects Wal1 NBS Contractors grams Area 非 非 No. in in $\mathrm{ft}^{2}$ Appendix

\begin{tabular}{|c|c|c|c|c|c|c|c|}
\hline & $\mathrm{N}$ & $\begin{array}{l}\text { Small Voids at Top } \\
\text { of NE Corner; Air } \\
\text { Infiltration at E } \\
\text { Side of Window }\end{array}$ & 3 & Yes & Yes & Yes & \\
\hline \multirow[t]{2}{*}{$\begin{array}{l}\text { Stairway } \\
\text { (1st Floor }\end{array}$} & & $\begin{array}{l}\text { Voids at Bottom } \\
\text { of Stairs and Air } \\
\text { Penetration from } \\
\text { Ceiling }\end{array}$ & 3 & Yes & Yes & Yes & $9-7$ \\
\hline & $\mathrm{E}$ & $\begin{array}{l}\text { Small Void in } \\
\text { Partition Wall }\end{array}$ & 1 & Yes & & & \\
\hline $\begin{array}{l}\text { Stairway } \\
\text { (2nd Floor }\end{array}$ & $\begin{array}{l}N \\
)\end{array}$ & $\begin{array}{l}\text { Defective Ceiling } \\
\text { Over Stairway }\end{array}$ & & Yes & Yes & Yes & $9-8$ \\
\hline \multirow[t]{2}{*}{$\begin{array}{l}\text { Northeast } \\
\text { Bedroom }\end{array}$} & N & $\begin{array}{l}\text { Defective Pitched } \\
\text { Ceiling (May be Due } \\
\text { to Shrinkage or } \\
\text { Moisture Damage) }\end{array}$ & & Yes & Yes & Yes & $9-9$ \\
\hline & $\mathrm{E}$ & $\begin{array}{l}\text { Insulation Missing } \\
\text { Below Window \& Inside } \\
\text { Closet; Air Leakage } \\
\text { on S Side of Window }\end{array}$ & 5 & Yes & Yes & Yes & \\
\hline \multirow{3}{*}{\multicolumn{2}{|c|}{$\begin{array}{l}\text { Southeast } \mathrm{E} \\
\text { Bedroom }\end{array}$}} & $\begin{array}{l}\text { Voids at SE Corner } \\
\text { of Window; Air } \\
\text { Penetration from } \\
\text { Ceiling }\end{array}$ & 5 & Yes & Yes & Yes & \\
\hline & & $\begin{array}{l}\text { Defective Sloped } \\
\text { Ceiling }\end{array}$ & 12 & Yes & Yes & Yes & $9-10$ \\
\hline & & $\begin{array}{l}\text { Voids Above Windows, } \\
\text { in } 1 \text { Partial Bay } \\
\text { Cavity at E of Windows; } \\
\text { Air Infiltration Below } \\
\text { W Window at SE Corner }\end{array}$ & & Yes & Yes & Yes & \\
\hline Bathroom & S & $\begin{array}{l}\text { Voids Above Window } \\
\text { and in Upper Part } \\
\text { of Wall }\end{array}$ & 2 & Yes & No & No & $9-11$ \\
\hline
\end{tabular}


Table IXa. Summary of Defects Observed in Portland House \#1

$\begin{array}{ccccc}\text { Room \& } & \text { Description of } & \text { Defective } & \text { Observed by } & \text { Thermo- } \\ \text { Orientation } & \text { Defects } & \text { Wall } & \text { NBS Contractors } & \text { grams } \\ & & \text { Area } & \text { N } 5 \text { 非 } 6 & \text { No. in } \\ & & \text { in } \text { f }^{2} & & \text { Appendix }\end{array}$

Southwest $S$ Volds Above Window

Bedroom

4 Yes Yes Yes

Volds at Both Upper

Yes Yes No

SE and SW Corners

W Volds in Upper Wall

at $S$ of Window and

Also in NW Corner

Northwest W Small Volds at Both

Bedroom

SW and NW Upper

Corners

N Defective Sloped

Ceiling at $W$ Side

of Window

9 Yes Yes Yes

Voids Above Window and at West Side of Window

Yes No Yes 9-13

Total Wall Area of

106

3 Yes Yes Yes

Insulation Volds Detected

Given in $\mathrm{ft}^{2}$ 
Table IXb. Environmental Conditions During Inspection of Portland Hours \#1

\begin{tabular}{|c|c|c|c|}
\hline & \multicolumn{3}{|c|}{ Contractors } \\
\hline & NBS & 非 & $\$ 6$ \\
\hline $\begin{array}{l}\text { Date } \\
\text { Time }\end{array}$ & $\begin{array}{r}3 / 15 / 79 \\
10: 00 \text { am }\end{array}$ & $\begin{array}{c}4 / 10 / 79 \\
7: 45-9: 30 \mathrm{pm}\end{array}$ & $\begin{array}{l}4 / 12 / 79 \\
9: 00 \mathrm{pm}\end{array}$ \\
\hline Outdoor Temperature & $35^{\circ} \mathrm{F}$ & $37^{\circ} \mathrm{F}$ & $45^{\circ} \mathrm{F}$ \\
\hline Indoor Temperature & $68^{\circ} \mathrm{F}$ & $67-68^{\circ} \mathrm{F}$ & \\
\hline Wind Speed (MPH) & $0-5$ & $0-10$ & \\
\hline Wind Direction & $\mathbf{W}$ & & \\
\hline
\end{tabular}




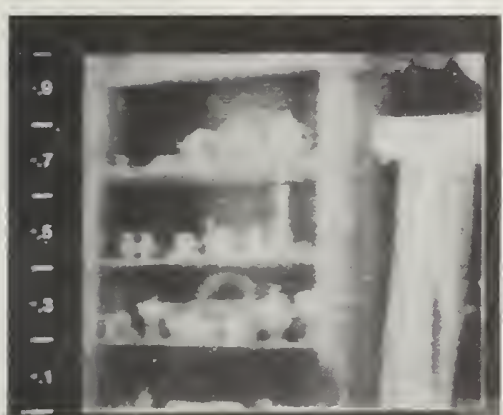

9-1

E wall of dining room.

(by NBS)

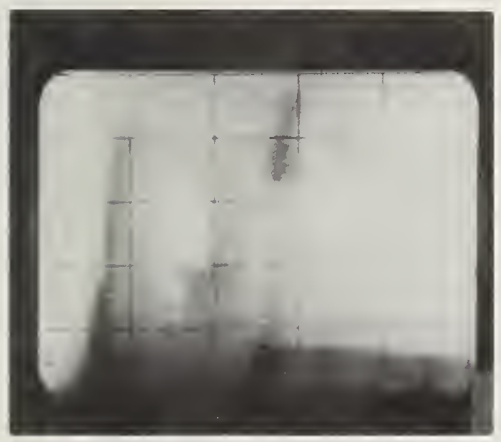

$$
9-4
$$

SE corner on $S$ of living room. (by contract 非)

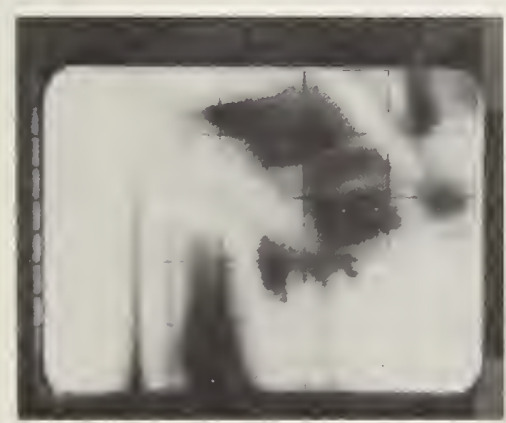

$$
9-7
$$

Bot tom of stairway on $\mathrm{N}$ of lst floor. (by contractor $\#^{5}$ )

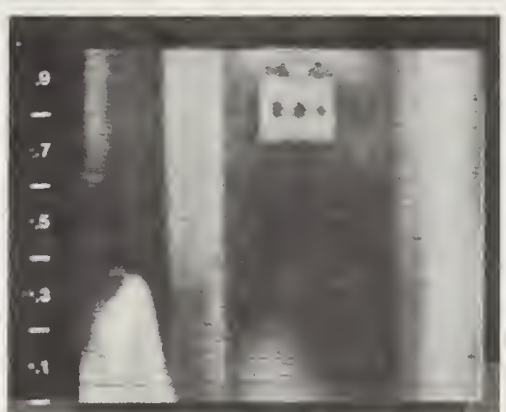

$9-2$

SW corner of

$S$ entrance.

(by NBS)

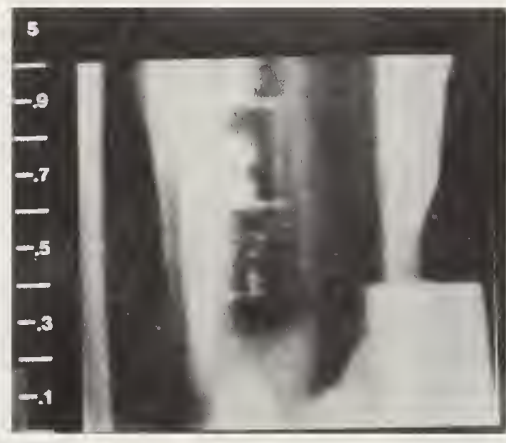

$$
\text { 9-5 }
$$

SW corner on $W$

of living room.

(by contractor 非5)

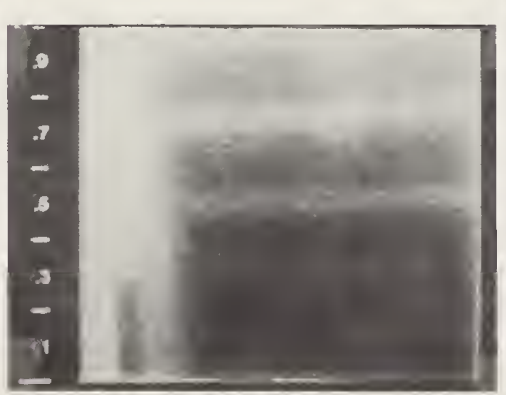

9-8

Over stairway

on $\mathrm{N}$ of 2 nd floor.

(by NBS)

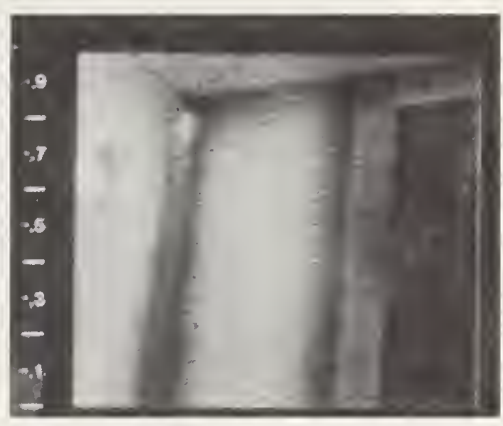

9-3

SE corner of

$S$ entrance.

(by NBS)

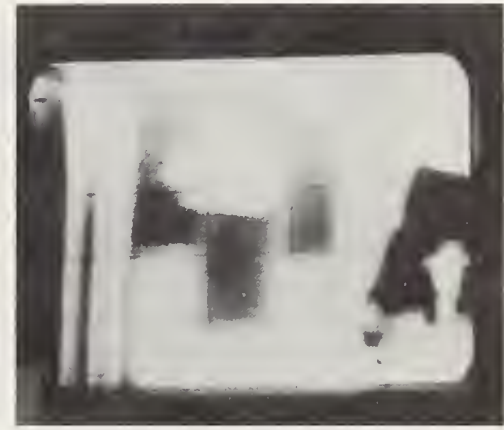

9-6

W wall of

living room.

(by contractor 非6)

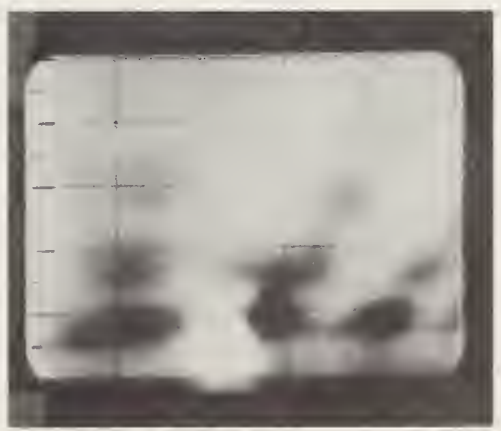

$$
\text { 9-9 }
$$

$\mathrm{N}$ pitched ceiling

of NE bedroom.

(by contractor 非)

$$
\text { A }-51
$$



Thermal Anomalies Observed in Portland House \#1 (continued)

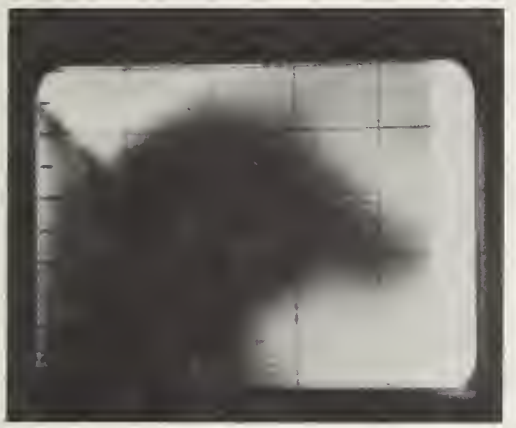

$9-10$

$S$ pitched ceiling of SE bedroom.

(by contractor $\# 5$ )

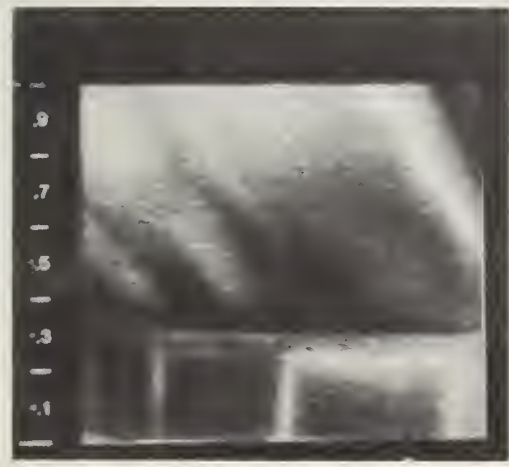

9-12

W pitched ceiling of NW bedroom.

(by NBS)

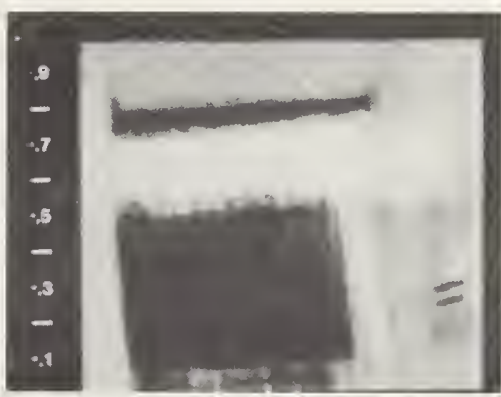

$$
\text { 9-11 }
$$

Above window on $S$ of bathroom.

(by NBS)

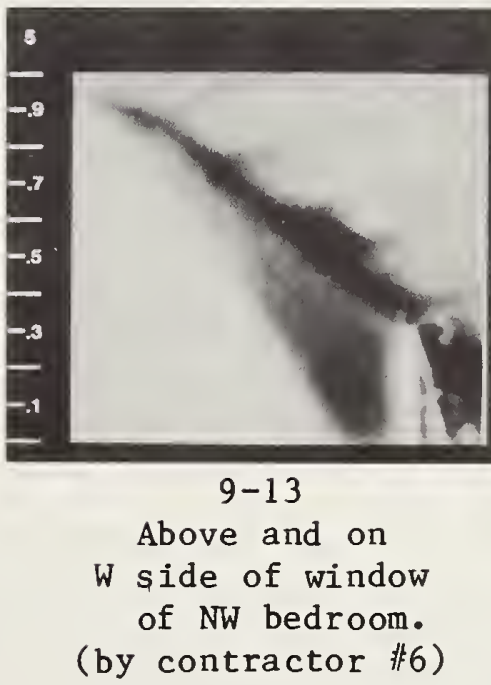





\section{Portland House 非}

This is a two-story, approximately 80 year old residence whose interior dimensions are $24 \mathrm{ft}$. In length, $42 \mathrm{ft}$. In width, and $9 \mathrm{ft}$. in wall height on the first floor, and $8 \mathrm{ft}$. In wall helght on the second floor; located in Portland, ME. There are 7 rooms of living space, with an attic and a basement. Its exterior construction contains wood siding and an asphalt shingle roof.

Prior to the weatherization program, this house had no insulation. An insulation contractor was instructed to insulate the walls and the attic with cellulose. After retrofitted options were completed this dwelling was inspected by NBS personnel and IR contractors $\equiv^{5}$, and $\equiv^{6}$. A sketch of the voids and the locations of heat loss obtained from thermograms and documents by NBS, as well as those by the IR contractors, is shown in figures $\mathrm{Xa}$ and $\mathrm{Xb}$.

In general, the most common heat loss areas in this house were found at the cellings. Very large uninsulated areas were found in pitched cellings upstairs as well as in flat cellings downstairs. Some of these uninsulated sloped cei1ings extended to the walls underneath; e.g., the south wall of the east bedroom. Due to the fact that the exact dimensions of these walls were unknown and the thermograms only showed the part of these voids which extended from the celling, the estimated wall area of volds for this dwelling will only be an approximation.

Thermographic inspection by NBS identified most known defects in this residence so that its results were used as a baseline for comparison purposes.

Contractors 非 5 and 非 6 failed to inspect several areas to identify the defective locations.

A detailed description of the defects observed by NBS as well as those by the IR contractors, is summarized in table Xa. Besides the total defective wall area in $\mathrm{ft}^{2}$ found by each inspection, table $\mathrm{Xa}$ also includes the defective wall areas in $\mathrm{ft}^{2}$ of each room of the house, analyzed from available thermograms. The total estimates of vold areas, without taking into account void areas of any cellings, is approximately $97 \mathrm{ft}^{2}$, which represents about 5 percent of the gross wall area. Table $\mathrm{Xb}$ presents the enviremental conditions documented from each inspection. Thermograms $10-1$ to $10-10$ are some examples which demonstrate the locations of heat loss anomalies, as they are referred to in the description in table Xa. 
Table Xa. Summary of Defects Observed In Portland House \#2

Room \&
Orientation

$$
\begin{aligned}
& \text { Description of } \\
& \text { Defects }
\end{aligned}
$$

Defective

Wal1

Observed by

Area

NBS Contractors

\#5 \#6

in $f t^{2}$

The rmo-

grams

No. in

Appendix

Kitchen E Missing Insulation

\& Laundry at Top:

Room

on $N$ of Door

1 Yes Yes Yes 10-1

On S of Door

Yes Yes No

S Missing Insulation

at Top:

On $E$ of window

5 Yes No Yes 10-2

On $W$ of Window

Yes Yes Yes

Alr Leakage at SE

Corner

Yes Yes Yes

W Small Void at Top of NW Corner; Alr Penetration From Ceiling

Bathroom W Alr Infiltration at Top \& NW Corner

Yes No No

N Small Vold at E

Side of Window; Alr

Penetration From

Ceiling

Dining

N Air Penetration from

Ceiling

Small Vold at E Side of Window

1 Yes Yes Yes

Room

S Smal1 Void at Top of SW Corner of Window

3 Yes No No

7 Yes No Yes 10-3

Yes No Yes

1 Yes No No 10-4 
Table Xa. Summary of Defects Observed in Portland House \#2

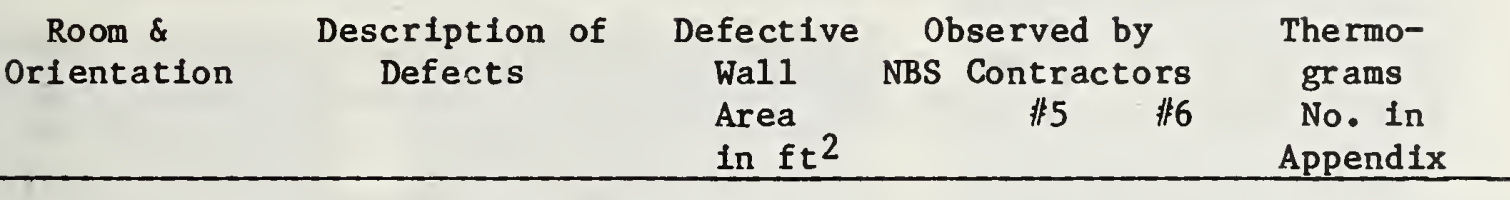

\begin{tabular}{|c|c|c|c|c|c|c|c|}
\hline $\begin{array}{l}\text { Living } \\
\text { Room }\end{array}$ & $\mathrm{E}$ & $\begin{array}{l}\text { Small Void at Top of } \\
\text { SE Corner of Window } \\
\text { Alr Penetration from } \\
\text { Ceiling \& Infiltration } \\
\text { Around Window \& Door, } \\
\text { and at NE \& SE Corners }\end{array}$ & 1 & Yes & Yes & Yes & $10-5$ \\
\hline $\begin{array}{l}\text { Stairway } \\
\text { (1st Floor }\end{array}$ & $\stackrel{-a}{n}$ & $\begin{array}{l}\text { Missing Insulation } \\
\text { Around Light Switch } \\
\text { Area }\end{array}$ & & Yes & Yes & Yes & $10-6$ \\
\hline \multirow[t]{3}{*}{$\begin{array}{l}\text { Hallway } \\
\text { (2nd Floor }\end{array}$} & W & $\begin{array}{l}\text { Missing Insulation } \\
\text { in } 4 \text { Upper Bay } \\
\text { Cavities }\end{array}$ & 14 & Yes & Yes & Partial & $10-7$ \\
\hline & N & $\begin{array}{l}\text { Missing Insulation } \\
\text { at Top of Window }\end{array}$ & 4 & Yes & Yes & Yes & $10-8$ \\
\hline & & $\begin{array}{l}\text { Air Penetration from } \\
\text { Celling }\end{array}$ & & Yes & Yes & Yes & \\
\hline \multirow[t]{5}{*}{$\begin{array}{l}\text { East } \\
\text { Bedroom }\end{array}$} & $\mathrm{N}$ & $\begin{array}{l}\text { Uninsulated Pitched } \\
\text { Ceiling }\end{array}$ & & Yes & Yes & Yes & \\
\hline & E & $\begin{array}{l}\text { Voids Above Window; } \\
\text { Voids Under \& at } N \\
\text { Side of Window }\end{array}$ & 12 & Yes & Yes & Yes & \\
\hline & & $\begin{array}{l}\text { Defective Pitched } \\
\text { Ceiling }\end{array}$ & & Yes & Yes & No & \\
\hline & S & $\begin{array}{l}\text { Uninsulated Pitched } \\
\text { Ceiling }\end{array}$ & 38 & Yes & No & Yes & $10-9$ \\
\hline & & $\begin{array}{l}\text { Uninsulated Entire } \\
\text { Wall Area }\end{array}$ & & Yes & No & Yes & $10-10$ \\
\hline \multirow{2}{*}{\multicolumn{2}{|c|}{$\begin{array}{l}\text { West } \\
\text { Bedroom }\end{array}$}} & $\begin{array}{l}\text { Uninsulated Sloped } \\
\text { Ceiling }\end{array}$ & 6 & Yes & Yes & Yes & $10-11$ \\
\hline & & $\begin{array}{l}\text { Some Shrinkage of } \\
\text { Insulation in Wall }\end{array}$ & & Yes & No & No & \\
\hline
\end{tabular}


Table Xa. Summary of Defects Observed in Portland House \#2

Room \&

Orientation

$$
\begin{gathered}
\text { Description of } \\
\text { Defects }
\end{gathered}
$$

Defective

Wal1

Area

in $f t^{2}$
Thermo-

grams

No. In

Append 1x
W Same Vold at Top of NW Corner

Defective Pitched Ceiling

N Uninsulated PItched Celling
4 Yes Yes Yes

Yes Yes Yes

Yes Yes Yes

Total Wall Area of

$\begin{array}{llll}97 & 97 & 43 & 67\end{array}$

Insulation Volds Detected

Given in $\mathrm{ft}^{2}$

Table Xb. Environmental Conditions During Inspection of Portland House 非

\begin{tabular}{lccc} 
& NBS & Contractor & $\# 6$ \\
\hline Date & $3 / 15 / 79$ & $4 / 10 / 79$ & $4 / 12 / 79$ \\
Time & $1: 00 \mathrm{pm}$ & $6: 15-7: 30 \mathrm{pm}$ & $7: 00 \mathrm{pm}$ \\
Outdoor Temperature & $38^{\circ} \mathrm{F}$ & $40^{\circ} \mathrm{F}$ & $45^{\circ} \mathrm{F}$ \\
Indoor Temperature & $73^{\circ} \mathrm{F}$ & $70^{\circ}-75^{\circ} \mathrm{F}$ & \\
Wind Speed(MPH) & $0-5$ & 5 & \\
Wind Direction & $\mathrm{W}$ & & \\
\hline
\end{tabular}




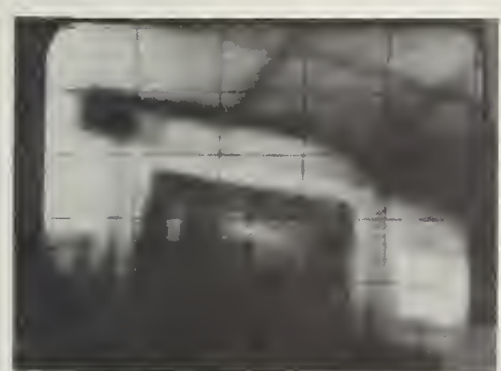

10-1

Above door on $E$ of kitchen. (by contractor 非)

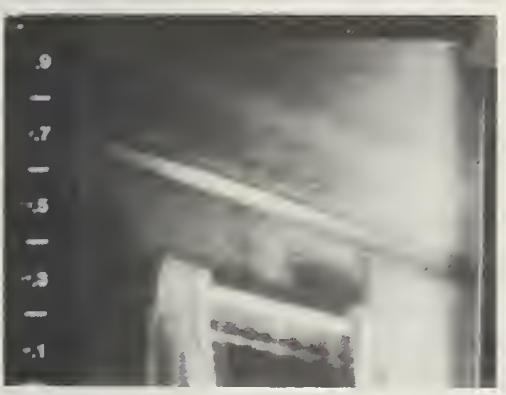

$$
10-4
$$

Above window on $S$ of dining room. (by NBS)

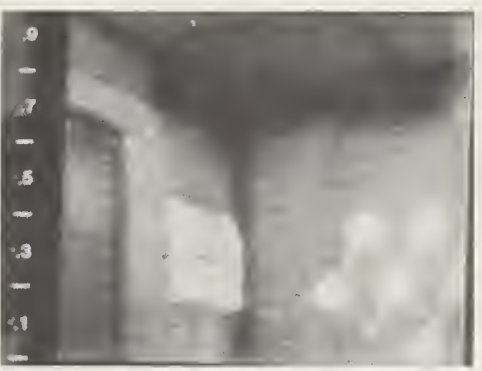

$10-2$

SE corner of kitchen

(by NBS)

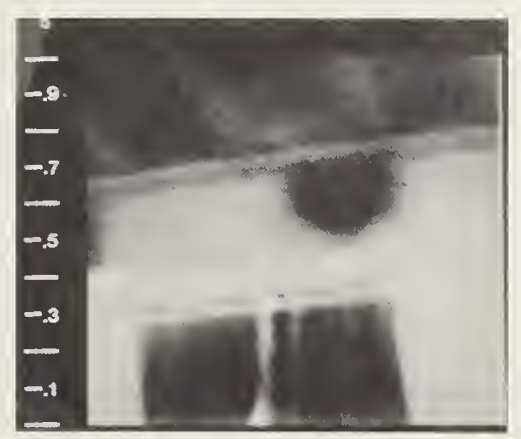

$10-5$

Above window on $E$ of living room. (by contractor 非)

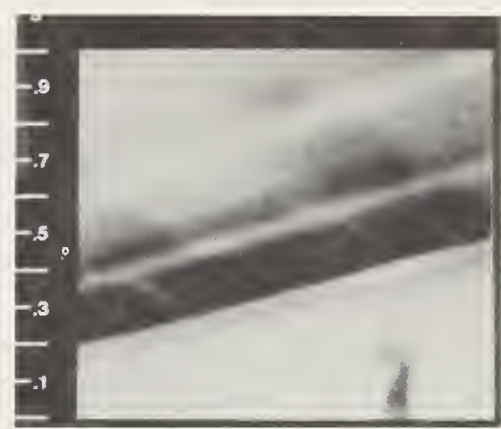

$10-3$

Ceiling on $\mathrm{N}$ side dining room. (by contractor 非)

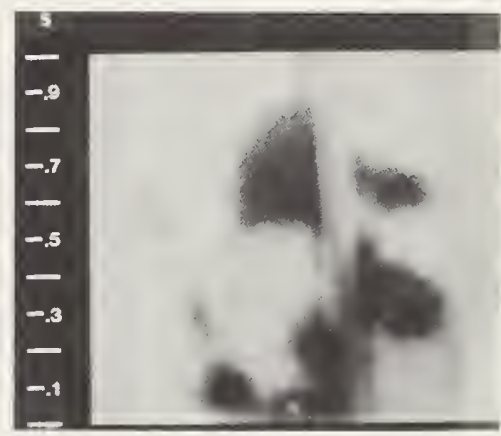

$10-6$

Around light switch on $\mathrm{N}$ wall of stairway on lst floor (by contractor \#6)

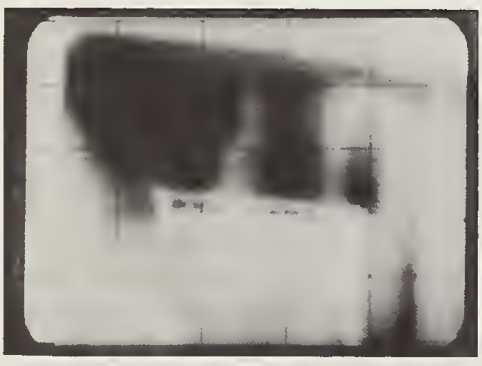

$10-7$

$W$ wall of hallway on 2 nd floor. (by contractor 非)

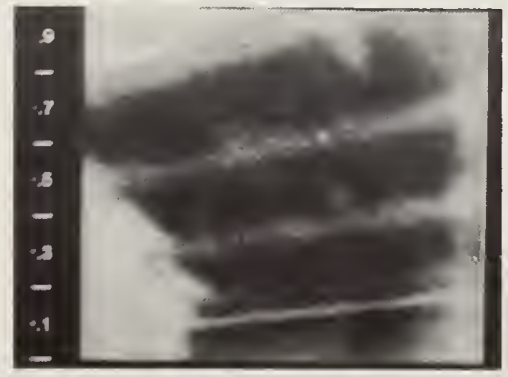

$$
\text { 10-9 }
$$

$S$ pitched ceiling of $E$ bedroom (by NBS)

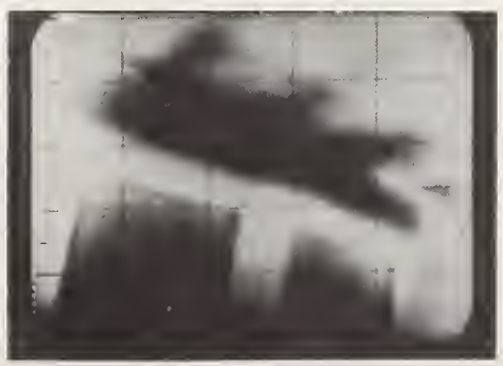

$$
\text { 10-8 }
$$

$\mathrm{N}$ wall of hallway on 2 nd floor. (by contractor 非)

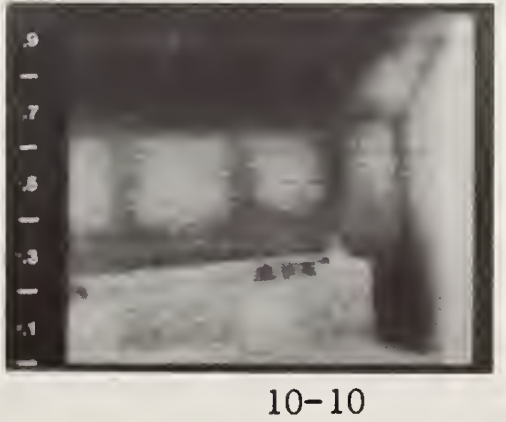

$\mathrm{S}$ side of $\mathrm{W}$ bedroom. (by NBS) 

XI. Portland House \#3

This is a one-story, approximately 40 year old residence whose interior dimensions are $30 \mathrm{ft}$. In length, $33 \mathrm{ft}$. in width, and $8 \mathrm{ft}$. in wall height; located in Portland, ME. There are 6 rooms of living space, with an attic and a basement. Its exterior construction contains wood frame siding and an asphalt shingle roof.

Prior to the weatherization program, this house had no insulation. An insulation contractor was instructed to insulate the walls and the attic with cellulose. After retrofitted options were completed, this dwelling was inspected by IR contractors $\$ 5$, 非6, and the local staff of CSA, as representatives for NBS. A sketch of the voids and the locations of heat loss obtained from thermograms and documents by NBS, as well as those by the IR contractors, is shown in figure XIa.

Generally speaking, the quality of insulation work in this dwelling was relatively poor, as the house was observed to have more than ten bay cavity voids, voids above most windows, air infiltration, and air penetration.

Thermographic inspection by local staff of CSA to represent NBS did not cover all of the rooms of this residence. Comparison of area of defects should rely only on thermograms submitted by contractors. Results from NBS can only be considered as supporting documents, as it failed to inspect the kitchen, the bathroom, the east side of the living room, and the east side of the northeast bedroom. Hence, the discrepency in estimated void areas between NBS and contractors (or the combined areas) can be expected.

Contractors $\# 5$ and $\# 6$ failed to recognize some defective areas as well.

A detailed description of the defects observed by NBS as well as those by the IR contractors, is summarized in table XIa. Besides the total defective wall area in $\mathrm{ft}^{2}$ found by each inspection, table XIa also includes the defective wall areas in $\mathrm{ft}^{2}$ of each room of the house, analyzed from available thermograms. The total estimates of void areas is approximately $165 \mathrm{ft}^{2}$, which represents about 20 percent of the gross wall area. Table XIb presents the environmental conditions documented from each inspection. Thermograms 11-1 to 11-16 are some examples which demonstrate the locations of heat anomalies, as they are referred to in the descriptions in table XIa. 

Table XIa. Summary of Defects Observed in Portland House 非

Room \& Description of Defective Observed by Thermo-

Orientation Defects Wall NBS Contractors grams

Area 非5 非6 No. in

in $\mathrm{ft}^{2} \quad$ Appendix

\begin{tabular}{llllll} 
Living & E & Missing Insulation: & \multicolumn{4}{c}{ (Partial) } \\
Room & Above \& Around Door; & 31 & Yes & Yes Yes & $11-1$ \\
& Above Window & & Yes & Yes Yes & $11-2$ \\
& in 1 Bay Cavity at & & Yes No No Yes & $11-3$
\end{tabular}

S Voids Above E Window and in 1 Bay Cavity at W Side of E Window; 16 Yes Yes Yes 11-4 Air Penetration from Fireplace Chimney

Voids Above W Window

Yes No No

Ceiling Defective Ceiling, May be Due to

Mois ture Damage

No Yes No 11-5

Dining S Missing Insulation:

Room

Above Window

26 Yes Yes No

Below Window \& Bay Cavities at SE and SW Corner

Yes Yes Yes 11-6

11-7

Kitchen S Voids Above Door \& Air Leakage Above \& Underneath Door

2 No Yes Yes 11-8

W Voids Above Window and in 2 Partial Bay Cavities at $N \& S$ of Wind ow

Northwest $\mathrm{W}$ Voids Above, Below, Bedroom and in Partial Bay Cavities at $N \& S$ of Window

Missing Insulation Inside Closet 
Table XIa. Summary of Defects Observed in Portland House \#3

Room \& Description of Defective Observed by ThermoOrlentation Defects Wall NBS Contractors grams Area \#5 \#6 No. in in $f t^{2} \quad$ Append 1x

\begin{tabular}{|c|c|c|c|c|c|c|c|}
\hline & $\mathbf{N}$ & $\begin{array}{l}\text { Volds Above Window } \\
\text { Volds in } 1 \text { Bay Cavity }\end{array}$ & 13 & Yes & Yes & Yes & $11-12$ \\
\hline & & $\begin{array}{l}\text { Between Window and } \\
\text { Closet }\end{array}$ & & Yes & No & Yes & \\
\hline \multirow[t]{3}{*}{ Bathroom } & $\mathrm{N}$ & Volds Above Window & 15 & Yes & Yes & Yes & \\
\hline & & $\begin{array}{l}\text { Volds in } 1 \text { Bay Cavity } \\
\text { in Tub Area }\end{array}$ & & No & Yes & Yes & $11-13$ \\
\hline & & $\begin{array}{l}\text { Volds in Lower SW } \\
\text { Corner of Window; } \\
\text { Alr Inf } 11 \text { tration } \\
\text { at NW Corner }\end{array}$ & & No & Yes & Yes & $11-14$ \\
\hline \multirow[t]{2}{*}{$\begin{array}{l}\text { Northeast } \\
\text { Bedroom }\end{array}$} & $\mathbf{N}$ & $\begin{array}{l}\text { Volds Above Window } \\
\& \text { In } 2 \text { Bay Cavities } \\
\text { at Both E \& W Sides } \\
\text { of Window; Alr } \\
\text { Infiltration at NW } \\
\text { Corner }\end{array}$ & 23 & Yes & Yes & Yes & $\begin{array}{l}11-15 \\
11-16\end{array}$ \\
\hline & $\mathbf{E}$ & Voids Above Window & 3 & No & No & Yes & \\
\hline $\begin{array}{l}\text { Total Wal } \\
\text { Insulatio } \\
\text { Given in }\end{array}$ & & $\begin{array}{l}\text { ea of } \\
\text { ids Detected }\end{array}$ & 164 & 135 & 144 & 154 & \\
\hline
\end{tabular}


Table XIb. Environmental Conditions During Inspection of Portland House \#3

\begin{tabular}{lccc} 
& NBS & Contractors & 非6 \\
\hline $\begin{array}{lcc}\text { Date } \\
\text { Time }\end{array}$ & $\begin{array}{l}3 / 16 / 79 \\
2: 00 \mathrm{pm}\end{array}$ & $7: 00-8: 15 \mathrm{pm}$ & $7: 30 \mathrm{pm}$ \\
Outdoor Temperature & $25^{\circ} \mathrm{F}$ & $36^{\circ} \mathrm{F}$ & $40^{\circ} \mathrm{F}$ \\
Indoor Temperature & $68^{\circ} \mathrm{F}$ & $68^{\circ} \mathrm{F}$ & \\
Wind Speed(MPH) & $0-5$ & 5 & \\
Wind Direction & NW & & \\
\hline
\end{tabular}





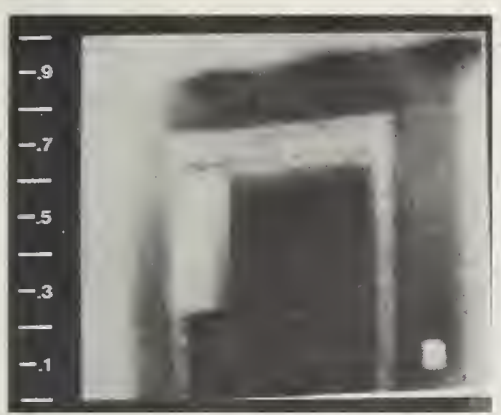

11-1

At top \& both sides of $\mathrm{E}$ door in living room. (by NBS)

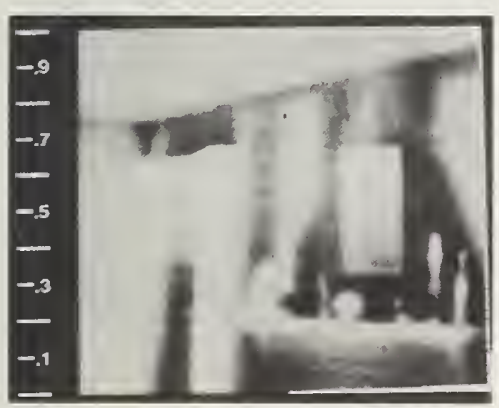

$11-4$

S wall of

living room.

(by NBS)

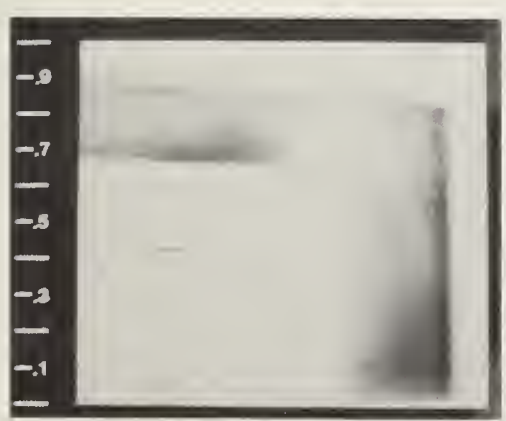

11-7

SW corner on

$S$ of dining room.

(by NBS)

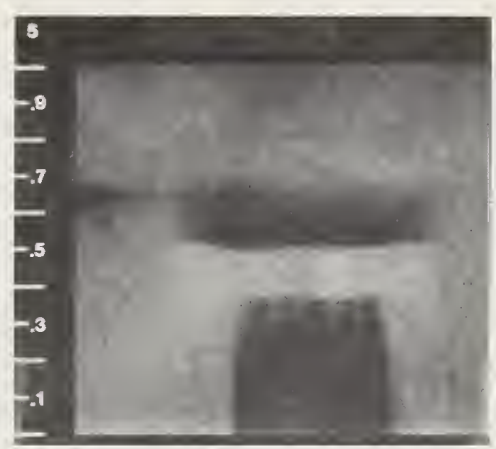

$$
11-2
$$

Above window on E of living room. (by contractor 非6)

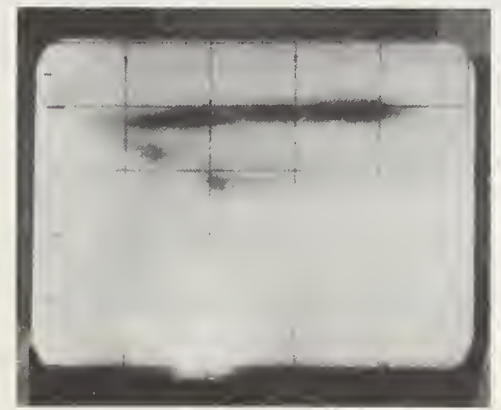

$$
\text { 11-5 }
$$

Ceiling of

living room.

(by contractor 非5)

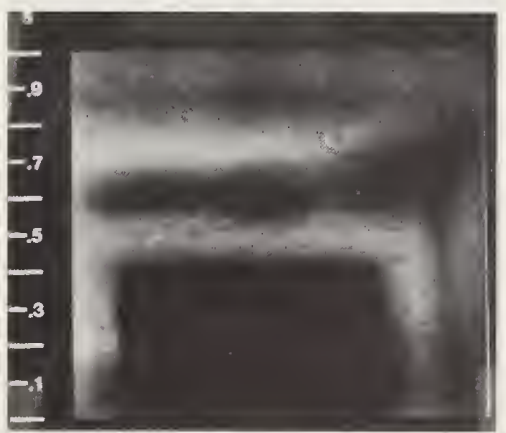

$$
\text { 11-8 }
$$

Above $S$ door

in kitchen.

(by contractor 非6)

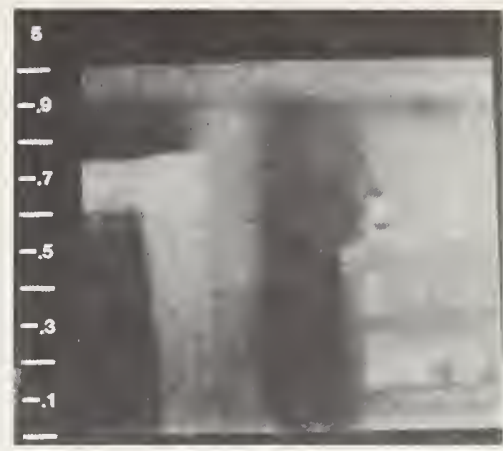

11-3

$\mathrm{SE}$ corner on $\mathrm{E}$

of living room.

(by contractor 非)

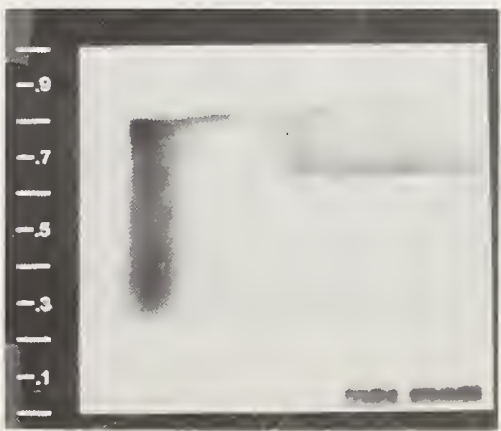

$$
\text { 11-6 }
$$

SE corner on $S$ of dining room. (by NBS)

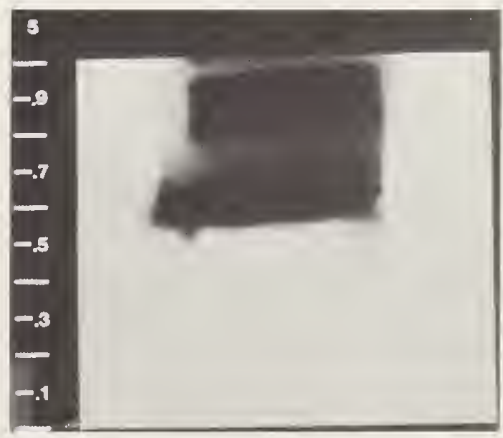

11-9

Underneath $\mathrm{S}$ door in kitchen. (by contractor 非) 

Thermal Anomalies Observed in Portland House 非 (continued)

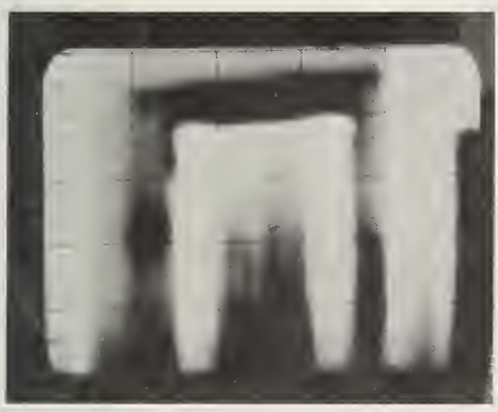

$$
11-10
$$

Around window on W of NW bedroom. (by contractor 非5)

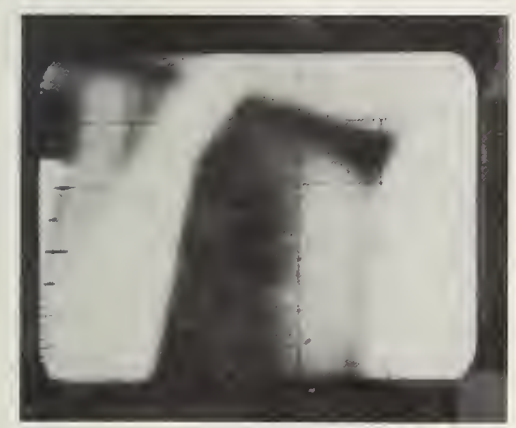

$$
11-13
$$

Tub area on $\mathrm{N}$ of bathroom. (by contractor 非5)

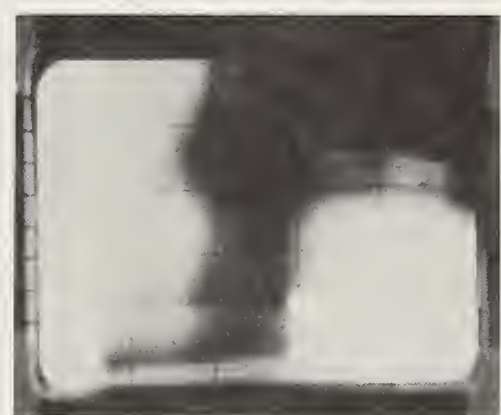

$$
11-11
$$

Inside closet on $W$ of NW bedroom. (by contractor 非)

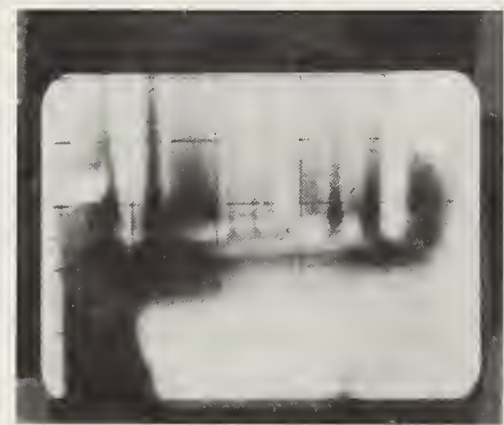

$11-14$

NW corner on

$\mathrm{N}$ of bathroom.

(by contractor 非5)

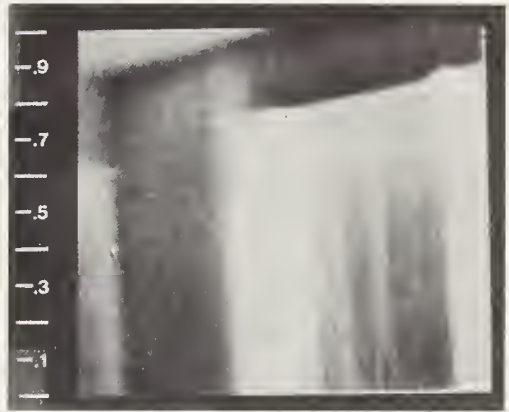

11-12

$\mathrm{N}$ wal1 of

NW bedroom.

(by NBS)

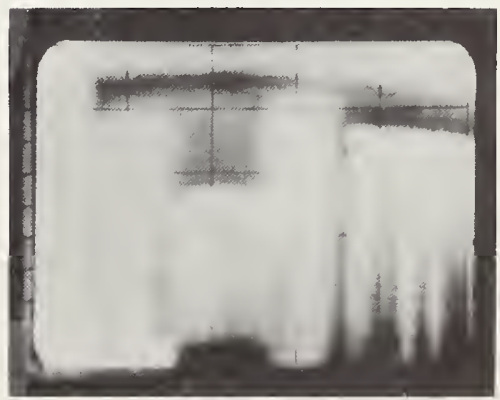

$$
11-15
$$

NW corner on $\mathrm{N}$ of NE bedroom.

(by contractor 非5)

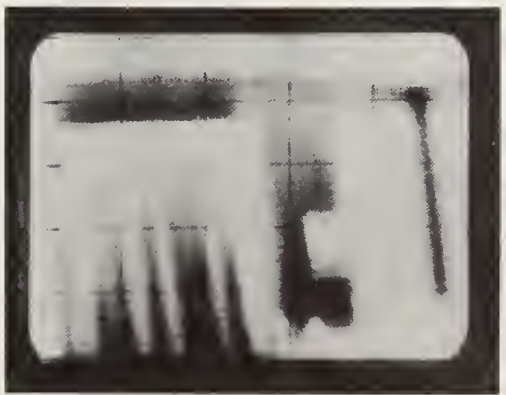

11-16

NE corner on $\mathrm{N}$

of NE bedroom.

(by contractor 非5) 



\section{Portland House 非}

This is a two-story, approximately 100 year old, L-shaped residence whose interior dimensions are $43 \mathrm{ft}$. in length, $31 \mathrm{ft}$. in width, and $8 \mathrm{ft}$. in wall height on the first floor, and $7 \mathrm{ft}$. in wall height on the second floor; located in Portland, ME. There are 8 rooms of living space with an attic and a basement. Its exterior construction contains wood frame siding and an asphalt shingle roof.

Prior to the weatherization program, this house had no insulation. An insulation contractor was instructed to insulate the walls and the attic with cellulose, and to install storm doors. After retrofitted options were completed this dwelling was inspected by NBS personnel and IR contractors 非, and 非6. A sketch of the voids and the locations of heat loss obtained from thermograms and documents by NBS, as well as those by the IR contractors, is shown in figures XIIa and XIIb.

Among three independent inspections, this dwelling seemed to be covered quite thoroughly. Insulation on the first floor is considered to be adequate except for the northeast corner and the southwest of the kitchen's west wall. Infiltration was found around most of the windows and door. Air leakage existed at most wall-to-wall and wall-to-ceiling joints. At the time of thermographic inspections, the second floor was unoccupied and its interior temperature was very low. This condition made it difficult to collect meaningful data especially in the room above the kitchen. Consequently, the entire kitchen ceiling was found to be very cold. On the second floor, the most common area of voids found by both contractors and NBS is above the windows and below the pitched ceiling.

This residence was inspected thoroughly by both contractors and NBS, except for a few areas that were missed by each group. The discrepency in estimating defective areas between contractor 5 and the others, was the east wall at the northeast corner of the northeast sitting room downstairs, where contractor 5 did not inspect. According to the report from contractor 非, due to sunshine throughout the day and the overheated radiator in the room, the room temperature was so high that the upper portion of the thermogram was obscured. Even though the upper wall portion of the northeast corner appeared to be warm, the studs were warmer than the bay areas. Hence it suggested that all bays around this corner were completely uninsulated. Nevertheless, inspection by NBS supported contractor 非's statement of an overheated radiator as it exhibited the identical phenomena of the studs being warmer than the bays. However, contractor 5 only observed the north side of this corner, without inspecting the east side; and, as a result, the defective wall area was estimated to be much less than the findings of contractor 非6 and NBS.

Another area that demonstrated the same phenomena of the studs being warmer than the bay areas was the south side of the kitchen. This finding might be due to the sun loading on the south side of the house, which did not imply uninsulated bays. Some thermograms from NBS' inspection indicated a cold ceiling in this room, which was caused by the unheated room upstairs. 

A detailed description of the defects observed by NBS as well as those by the IR contractors, is summarized in table XIIa. Besides the total defective wall area in $\mathrm{ft}^{2}$ found by each inspection, table XIIa also includes the defective wall areas in $\mathrm{ft}^{2}$ of each room of the house, analyzed from avallable thermograms and statements. The total estimates of vold areas is approximately $119 \mathrm{ft}^{2}$, which represents about 7 percent of the gross wall area. Table XIIb presents environmental conditions documented from each inspection. Thermograms 12-1 to 12-11 are some examples which demonstrate the locations of heat loss anomalies, as they are referred to in the descriptions in table XIIa. 
Table XILa. Summary of Defects Observed in Portland House 非

\begin{tabular}{ccccc}
$\begin{array}{c}\text { Room \& } \\
\text { Orientation }\end{array}$ & $\begin{array}{c}\text { Description of } \\
\text { Defects }\end{array}$ & $\begin{array}{c}\text { Defective } \\
\text { Wall } \\
\text { Area } \\
\text { in } \mathrm{ft}^{2}\end{array}$ & $\begin{array}{c}\text { Observed by } \\
\text { NBS Contractors }\end{array}$ & $\begin{array}{c}\text { Thermo- } \\
\text { grams } \\
\text { No. in }\end{array}$ \\
& & & \#p 6 Apendix \\
\hline
\end{tabular}

\begin{tabular}{|c|c|c|c|c|c|c|c|}
\hline $\begin{array}{l}\text { Front } \\
\text { Entrance }\end{array}$ & $N$ & $\begin{array}{l}\text { Small Void in Upper } \\
\text { NW Corner; Air } \\
\text { Leakage Under and } \\
\text { Around Door }\end{array}$ & 1 & Yes & Yes & Yes & \\
\hline \multirow[t]{2}{*}{$\begin{array}{l}\text { Northeast } \\
\text { Sitting } \\
\text { Room } \\
\text { (list Floor }\end{array}$} & r) & $\begin{array}{l}\text { Missing Insulation } \\
\text { in a Lot of Bay } \\
\text { Cavities, E of Window; } \\
\text { I Partial Bay Cavity } \\
\text { at W of Window }\end{array}$ & 28 & Yes & Yes & Yes & $12-1$ \\
\hline & E & $\begin{array}{l}\text { Missing Insulation } \\
\text { in } 3 \text { Bay Cavities } \\
\text { at NE Corner; Air } \\
\text { Infiltration Around } \\
\text { Windows }\end{array}$ & 30 & Yes & No & Yes & \\
\hline \multirow{5}{*}{\multicolumn{2}{|c|}{ Kitchen }} & $\begin{array}{l}\text { Smal1 Voids Above } \\
\text { Window }\end{array}$ & 1 & Yes & No & Yes & $12-2$ \\
\hline & & $\begin{array}{l}\text { Cold Ceiling Indicating } \\
\text { Unheated Room Upstairs }\end{array}$ & & Yes & No & Yos & $12-3$ \\
\hline & & $\begin{array}{l}\text { Cold Ceillng; Effect } \\
\text { of Sun Loading to } \\
\text { Show Warmer Studs in } \\
\text { Uninsulated Wall }\end{array}$ & & Yes & No & Yes & $12-4$ \\
\hline & & $\begin{array}{l}\text { Missing Insulation } \\
\text { in I Bay Cavity at SE }\end{array}$ & 23 & Yes & No & Yes & \\
\hline & & $\begin{array}{l}\text { Voids Behind Cabinet } \\
\text { and in I Lower Bay } \\
\text { Cavity Alr Penetration } \\
\text { from Lower NW Corner }\end{array}$ & & Yes & Yes & Yes & \\
\hline $\begin{array}{l}\text { Northwest } \\
\text { Bedroom } \\
\text { (list Floo }\end{array}$ & & $\begin{array}{l}\text { Small Volds Above } \\
\text { Window and at Upper } \\
\text { NW Corner Alr } \\
\text { Infiltration at Both } \\
\text { NW and SW Corners }\end{array}$ & 6 & Yes & Yes & Yes & \\
\hline
\end{tabular}


Table XIIa. Summary of Defects Observed in Portland House 非 4

$\begin{array}{ccccc}\begin{array}{c}\text { Room \& } \\ \text { Orientation }\end{array} & \begin{array}{c}\text { Description of } \\ \text { Defects }\end{array} & \begin{array}{c}\text { Defective } \\ \text { Wall }\end{array} & \text { Observed by } & \text { Thermo- } \\ & & \text { Area } & \text { Contractors } & \text { grams } \\ \text { In ft }{ }^{2} & & & \text { N5 } 5 \text { No. in } \\ \text { Appendix }\end{array}$

N Smal1 Void Above

Window; Alr 1 Yes No No

Infiltration at Both

$\mathrm{NE}$ and NW Corners

Northeast $N$ Air Infiltration

Bedroom and Penetration

Yes Yes No

(2nd Floor)

E Small Void at S Side

$\begin{array}{lllll}\text { of Window; Air } & 3 & \text { Yes Yes No 12-5 }\end{array}$

Inf 11 tration at $\mathrm{SE}$

and $\mathrm{NE}$ Corners

S Small Vold at SW 4 Yes No No 12-6

Corner

SothH E Voids Above Window

Bedroom and in Some Partial

(2nd Floor) Bay Cavitles; Air

15 No Yes Yes 12-7

Leakage from Celling

12-8

12-9

W Alr Penetration from Yes Yes No

Bathroom W Volds Below Pitched

(2nd Floor) Celling and at NW - 4 Yes No Yes 12-10

Northwest $N$ Small Vold at NE

Bedroom Corner Under

(2nd Floor) Pitched Celling

3 Yes Yes Yes 12-11

S Cold Pitched Ceiling Yes Yes No

Total Wall Area of

$119 \quad 105 \quad 68 \quad 110$

Insulation Voids Detected

Given in $\mathrm{ft}^{2}$ 
Table XIIb. Environmental Conditions During Inspection of Portland House \#4

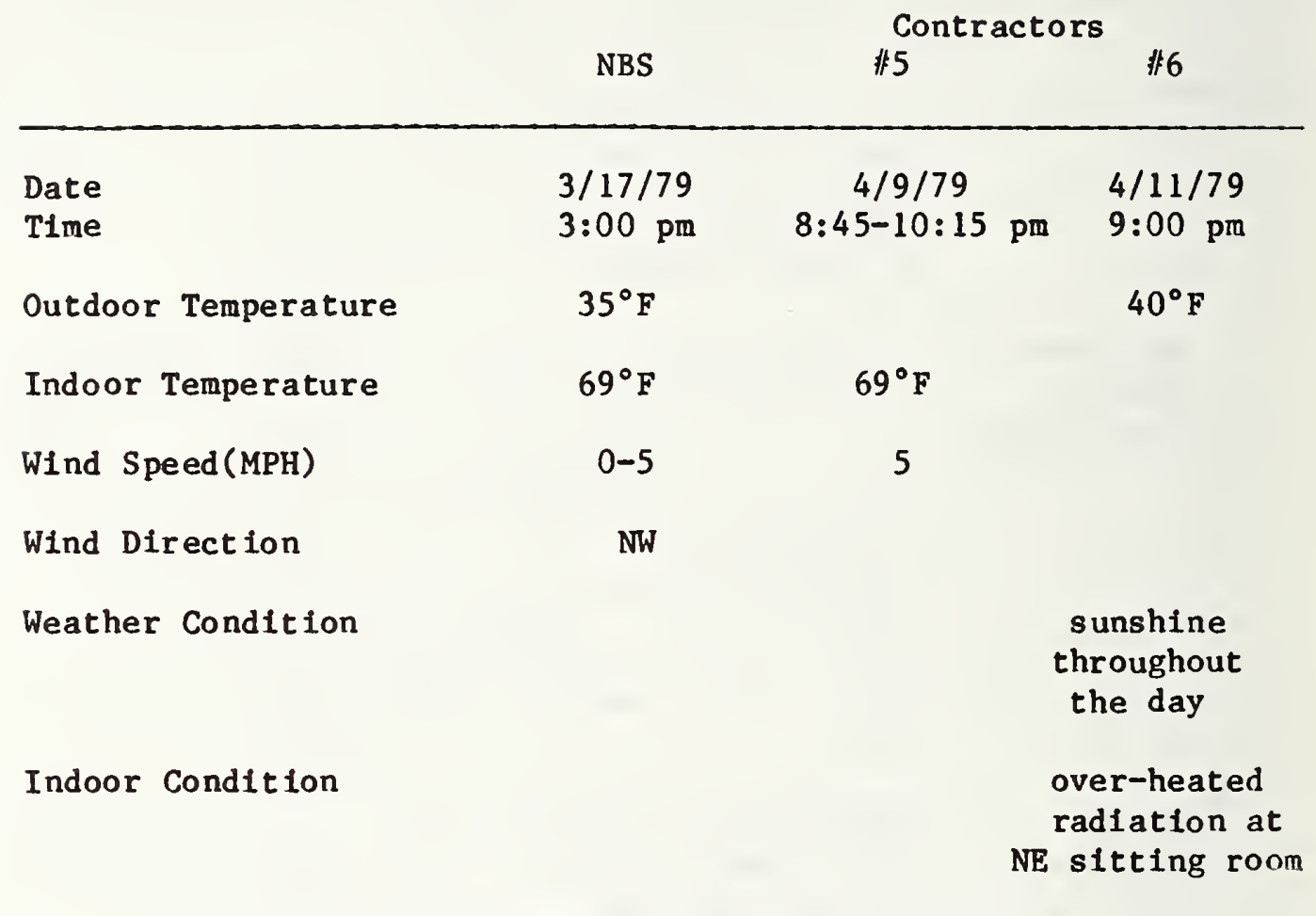


Thermal Anomalies Observed in Portland House 非

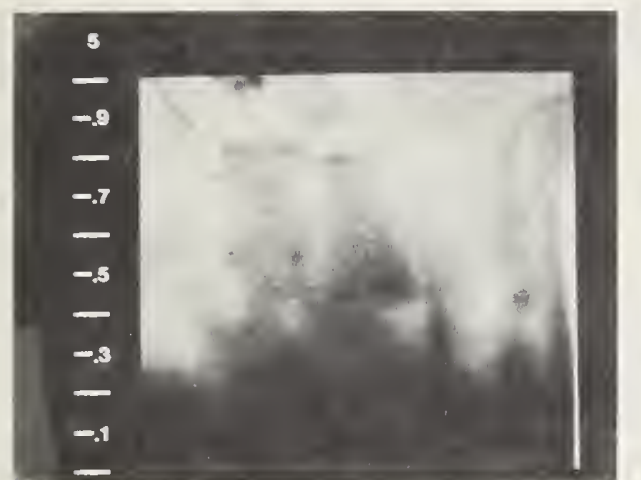

12-1

NE corner of

sitting room.

(by contractor 非6)

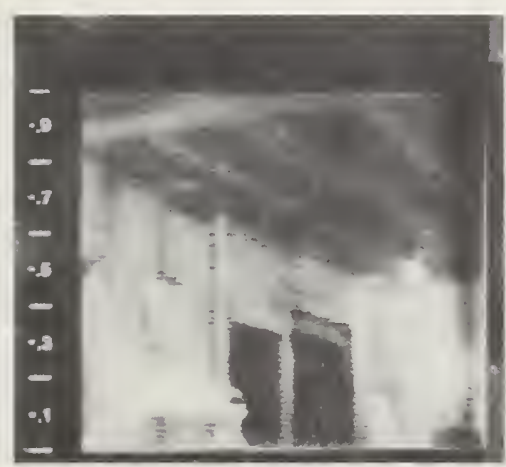

$12-3$

Cold ceiling on $E$

of kitchen.

(by NBS)

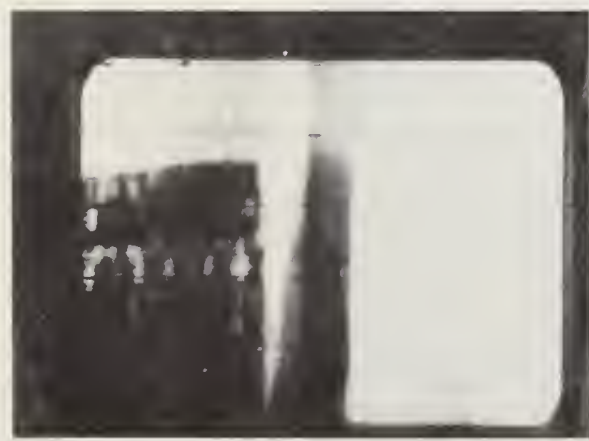

12-5

E wall of

NE bedroom.

(by contractor 非5)

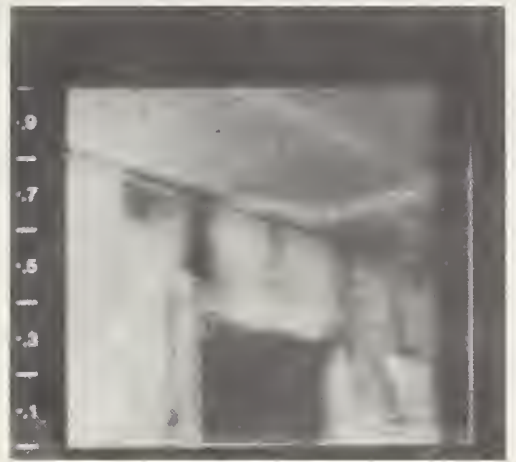

12-2

E wall of kitchen.

(by NBS)

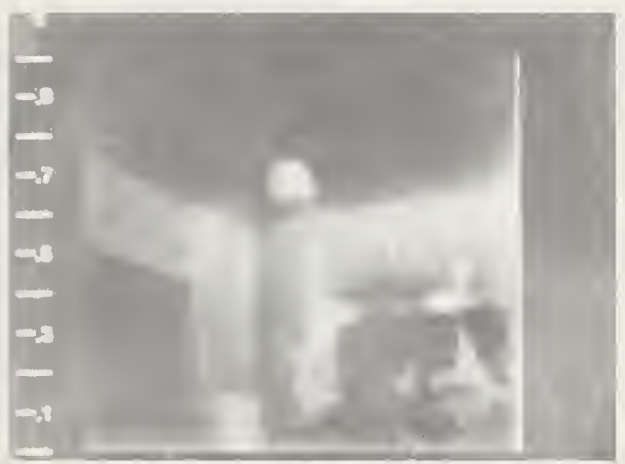

12-4

S wall of

kitchen.

(by contractor 非6)

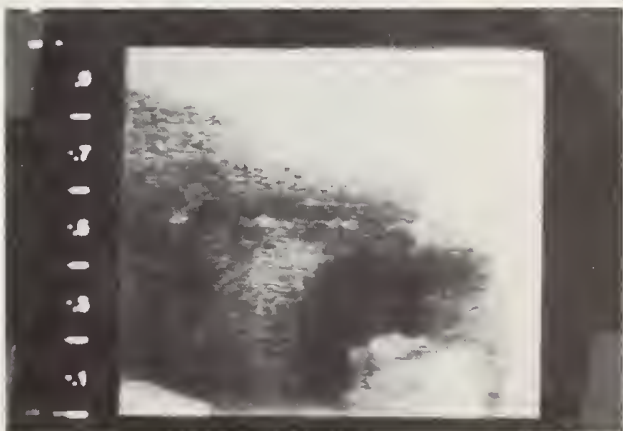

$$
\text { 12-6 }
$$

$S$ wall of $\mathrm{NE}$ bedroom.

(by NBS) 

Thermal Anomalies Observed in Portland House 非 (continued)

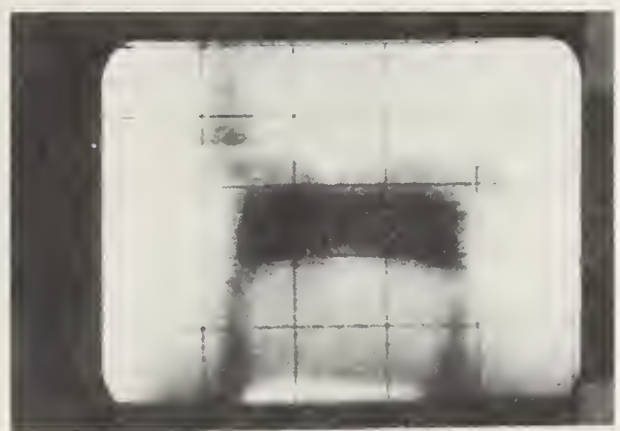

$12-7$

Above window on

$E$ of $S$ bedroom.

(by contractor 非5)

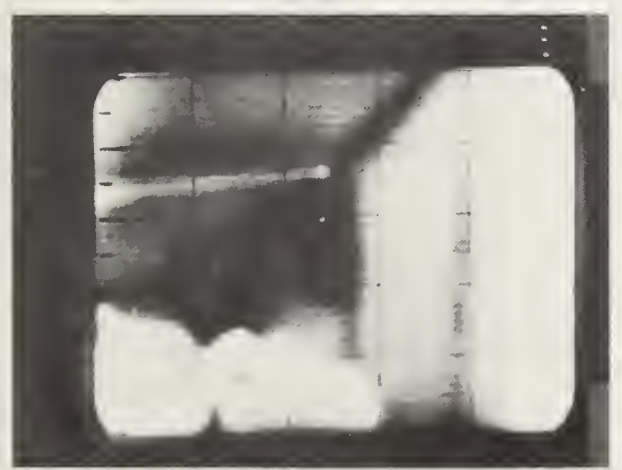

$12-9$

SE corner of

$S$ bedroom.

(by contractor 非5)

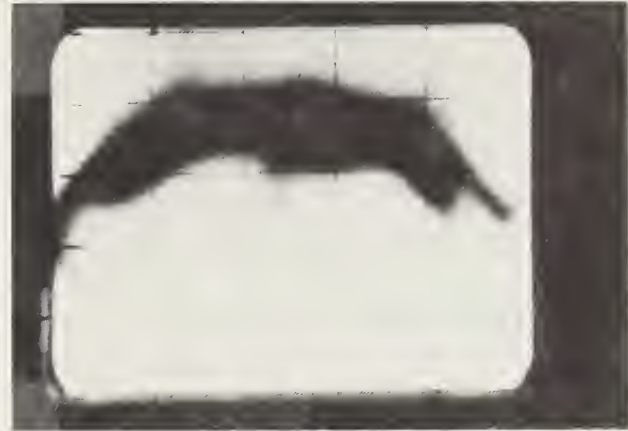

$12-8$

Below pitched ceiling on $\mathrm{E}$ of

$S$ bedroom.

(by contractor 非)

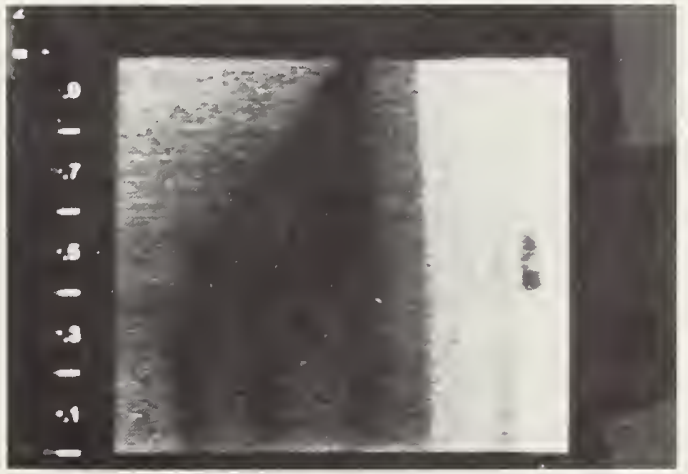

12-10

W wall of bathroom.

on 2nd floor.

(by NBS)

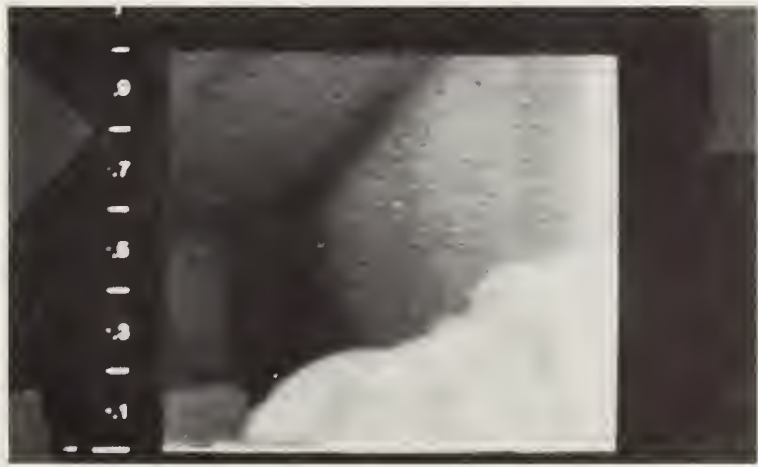

12-11

$\mathrm{NE}$ corner of NW bedroom on 2nd floor.

(by NBS)

$$
\text { A }-70
$$




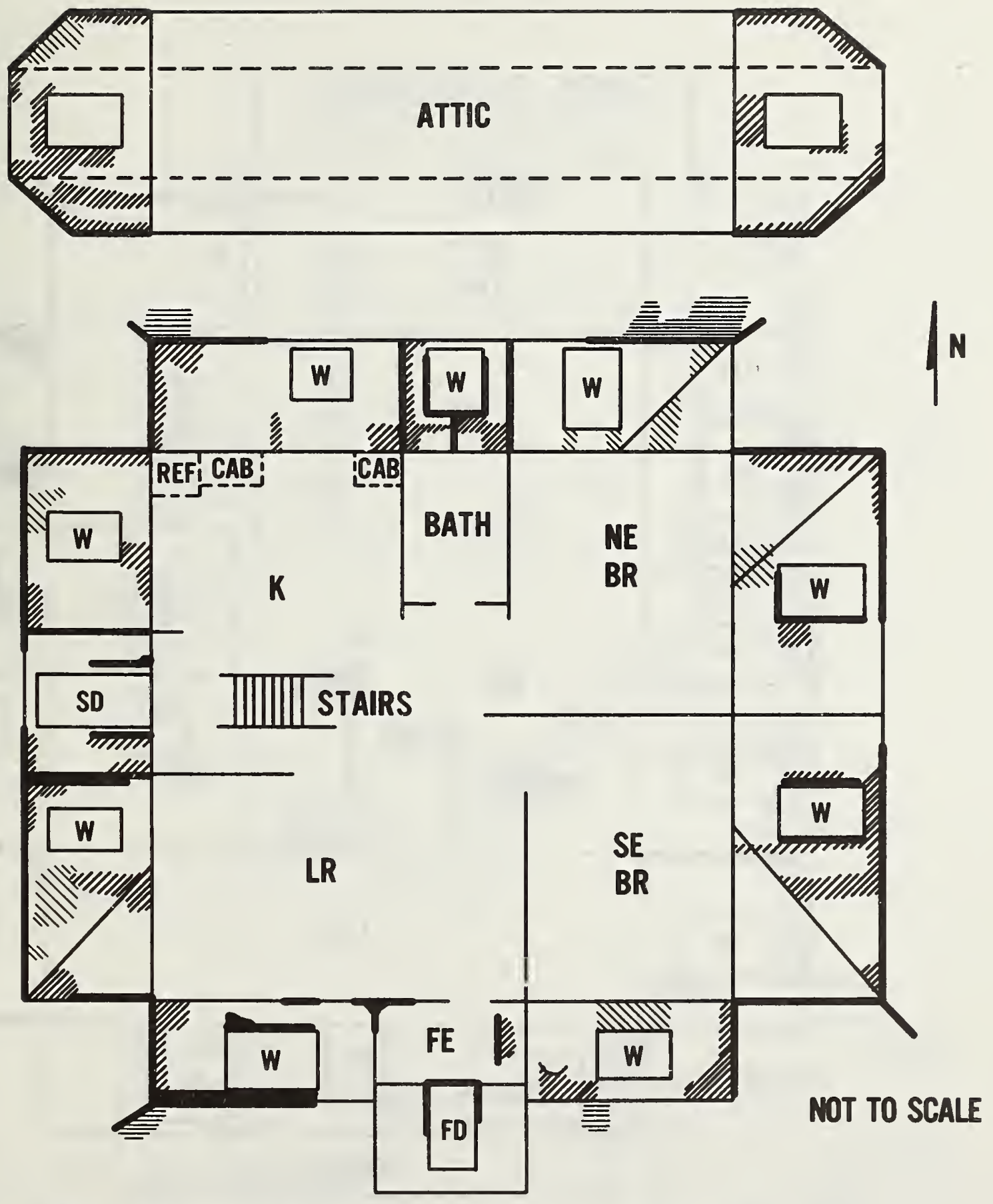

W COMPLETE VOIDS

$\mathbb{N}$ PARTIAL VOIDS (MISSING FOAM)

- INFILTRATION AND LEAKAGE PATHS

每 VOIDS OR PENETRATION FROM CEILING DEFECTS

Figure I. Thermal deficiencies observed in Fargo house $\|_{1}$ 


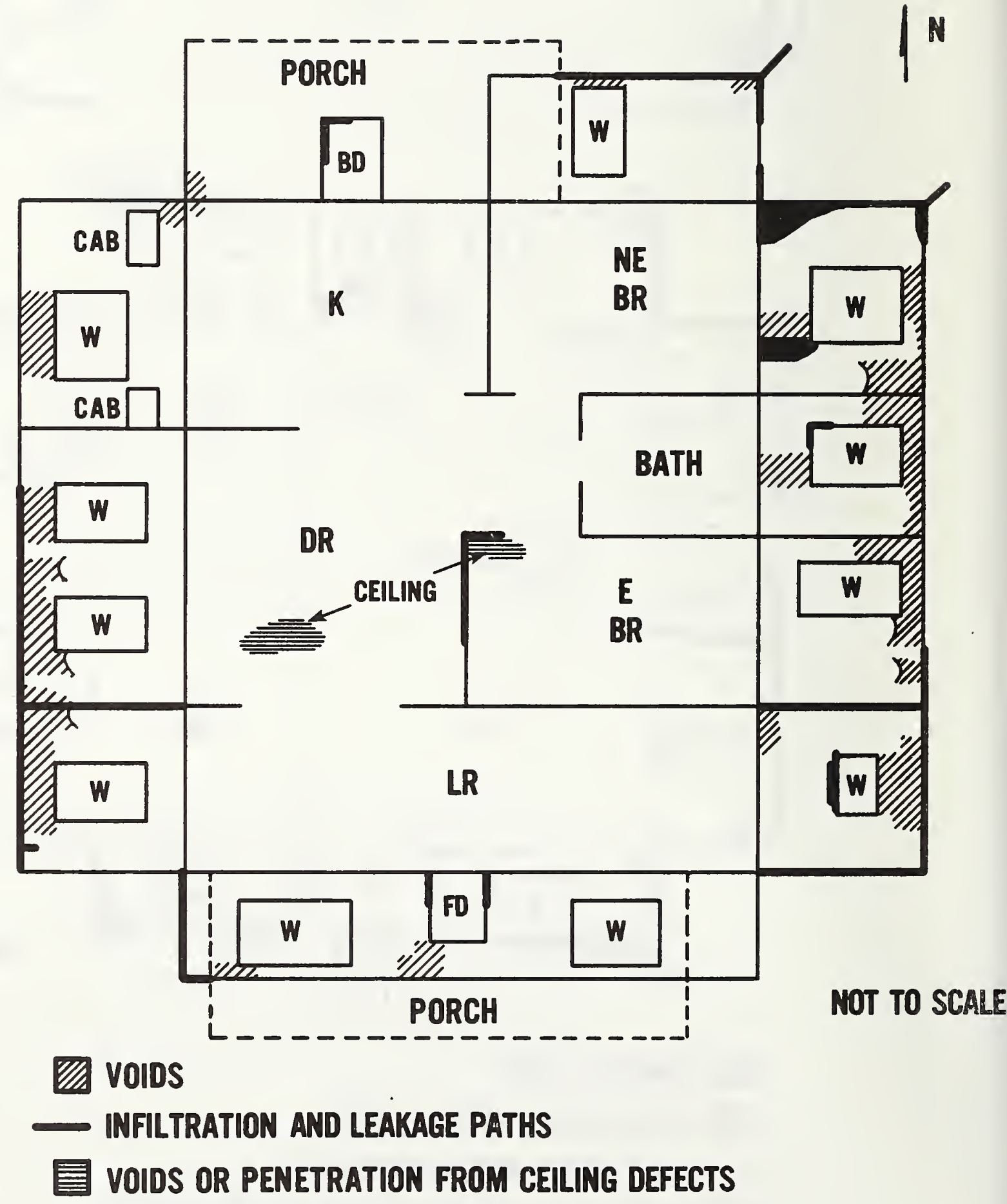

Figure II. Thermal deficiencies observed in Fargo house 非 A-72 

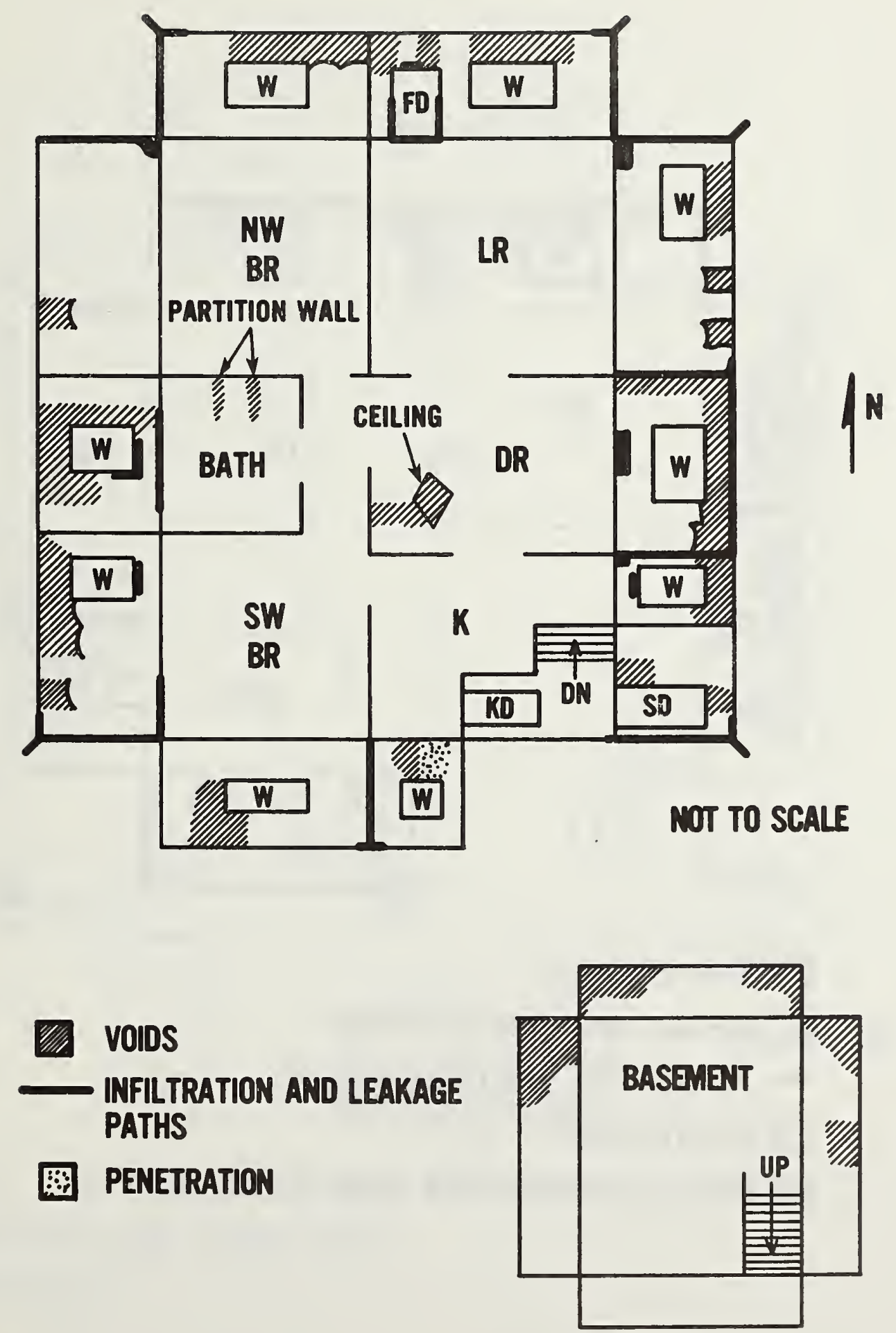

Figure III. Thermal deficiencies observed in Fargo house \#3 


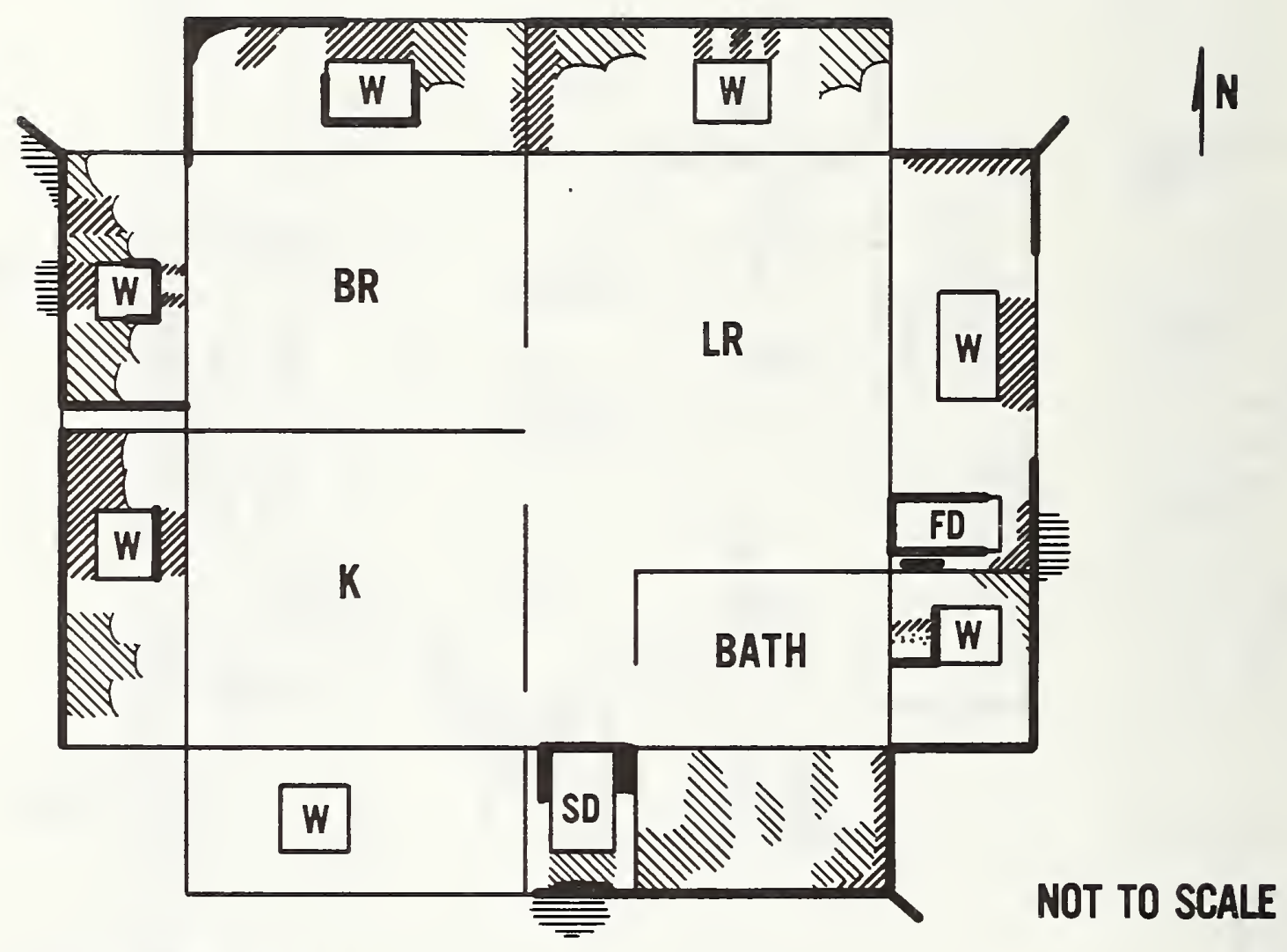

VOAPLETE VOIDS

$\mathbb{Q}$ PARTIAL VOIDS (MISSING FOAM)

- INFILTRATION AND LEAKAGE PATHS

PENETRATION

篔 VOIDS OR PENETRATION FROM CEILING DEFECTS

Figure IV. Thermal deficiencies observed in Fargo house $\$ 4$ 


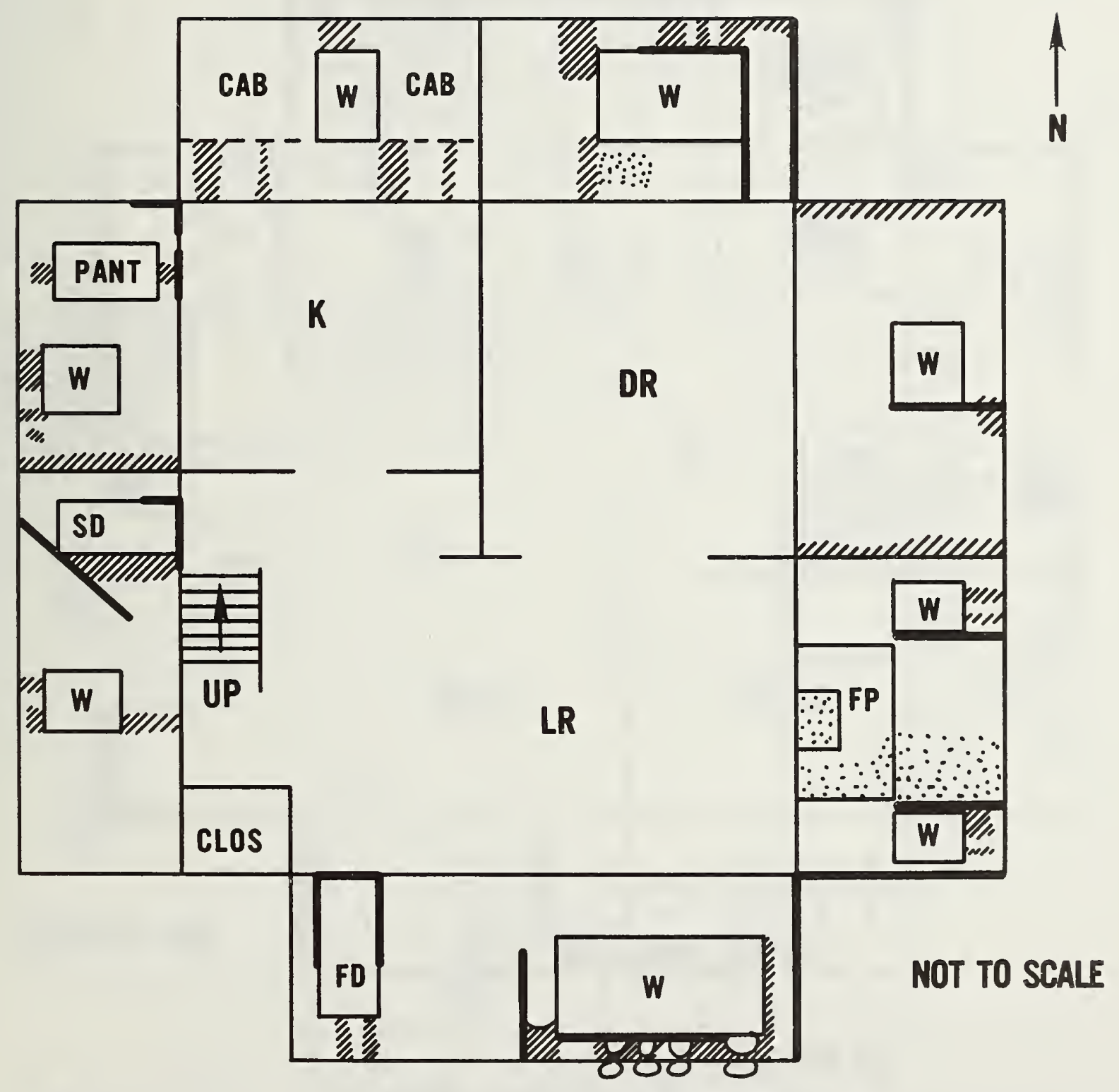

VOIDS

INFILTRATION AND LEAKAGE PATHS

PENETRATION

Figure Va. Thermal deficiencies observed on the first floor in Minneapolis-St. Paul house 非 1

$$
\text { A-75 }
$$




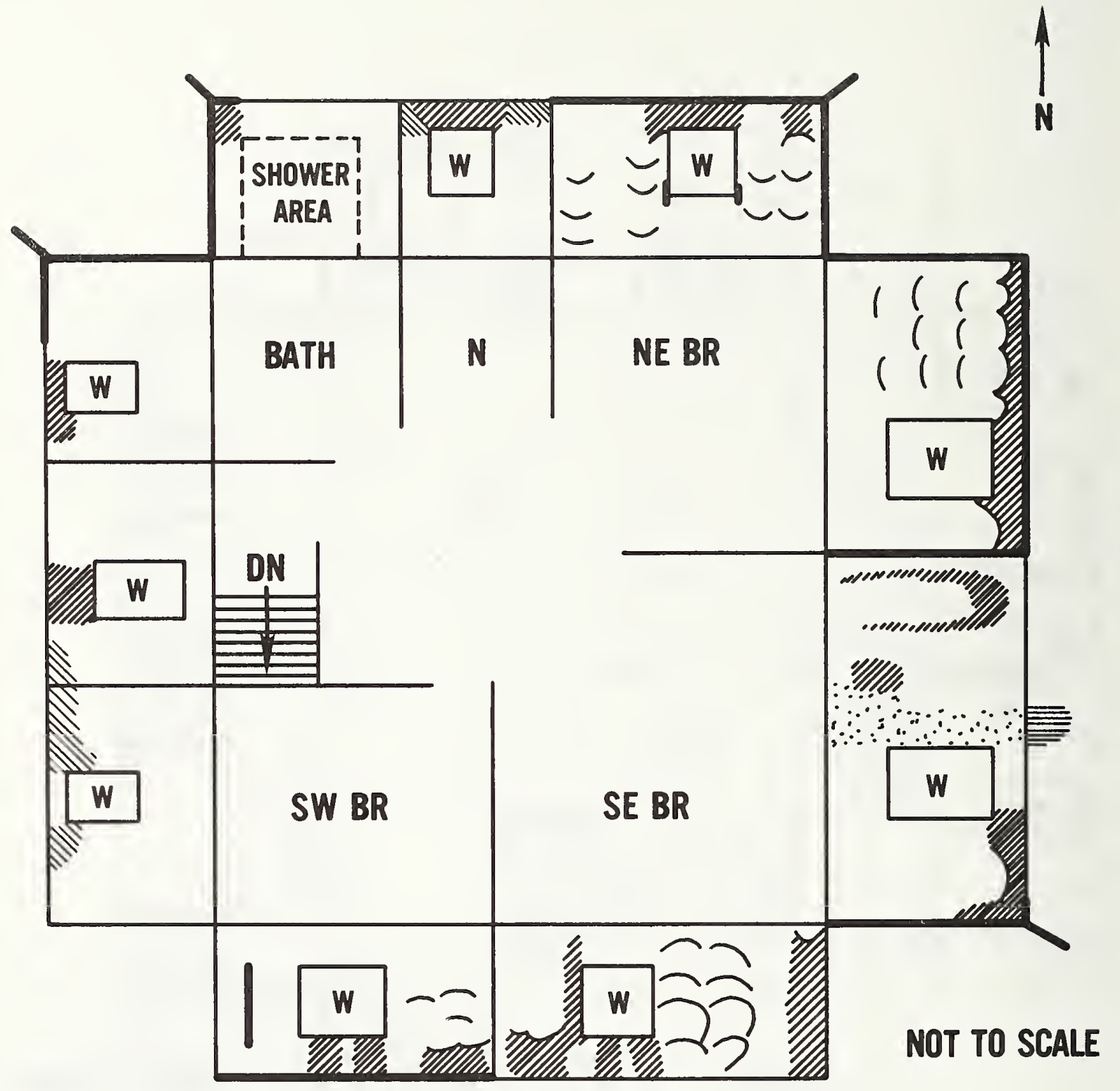

YOA VOIDS

- INFILTRATION AND LEAKAGE PATHS

PENETRATION

VOIDS OR PENETRATION FROM CEILING DEFECTS

N VOIDS DETECTED BY EXTERIOR THERMOGRAMS

Figure Vb. Thermal deficiencies observed on the second floor in Minneapolis-St. Paul house \#1 


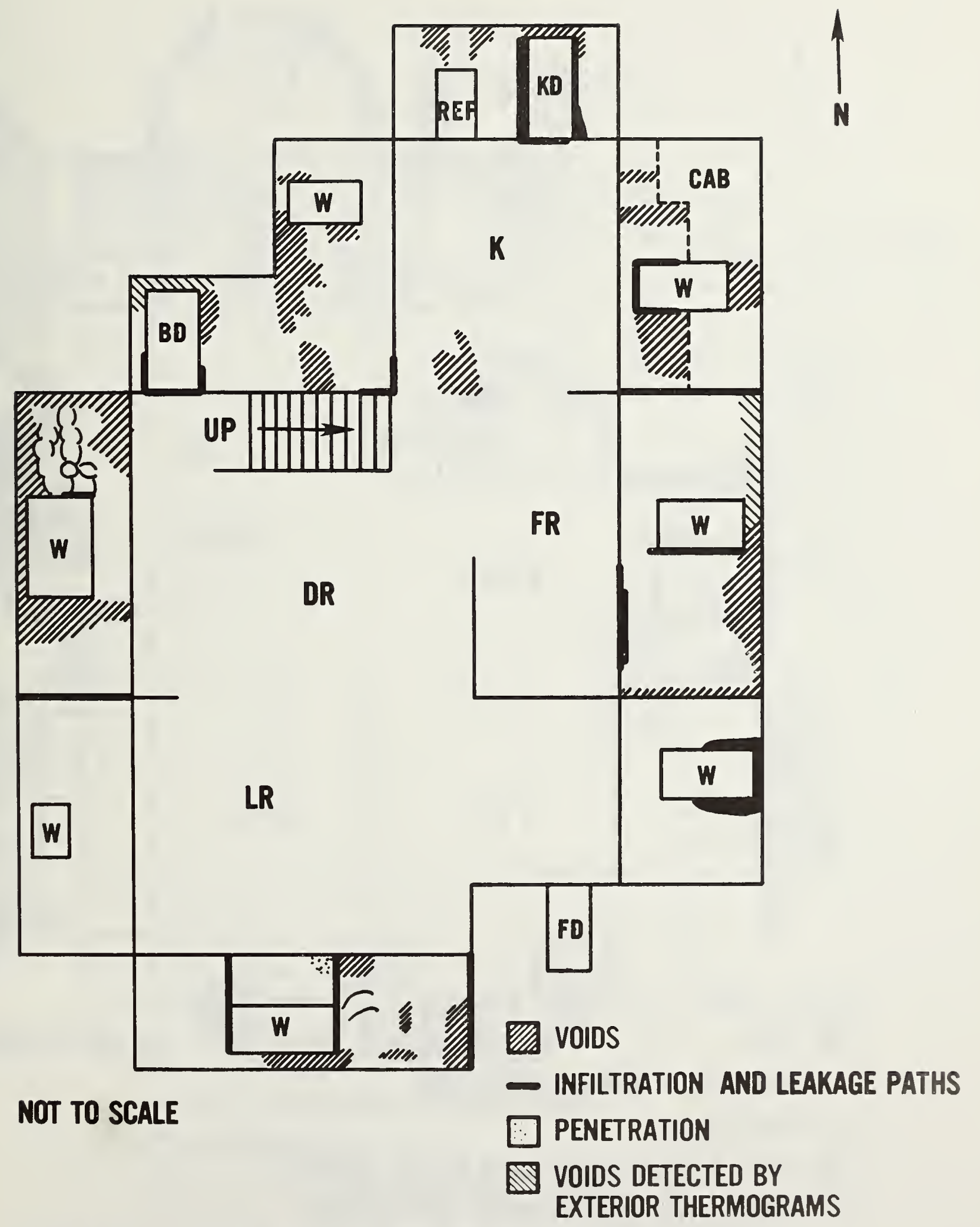

Figure VIa. Thermal deficiencies observed on the first floor in Minneapolis-St. Paul house 非 


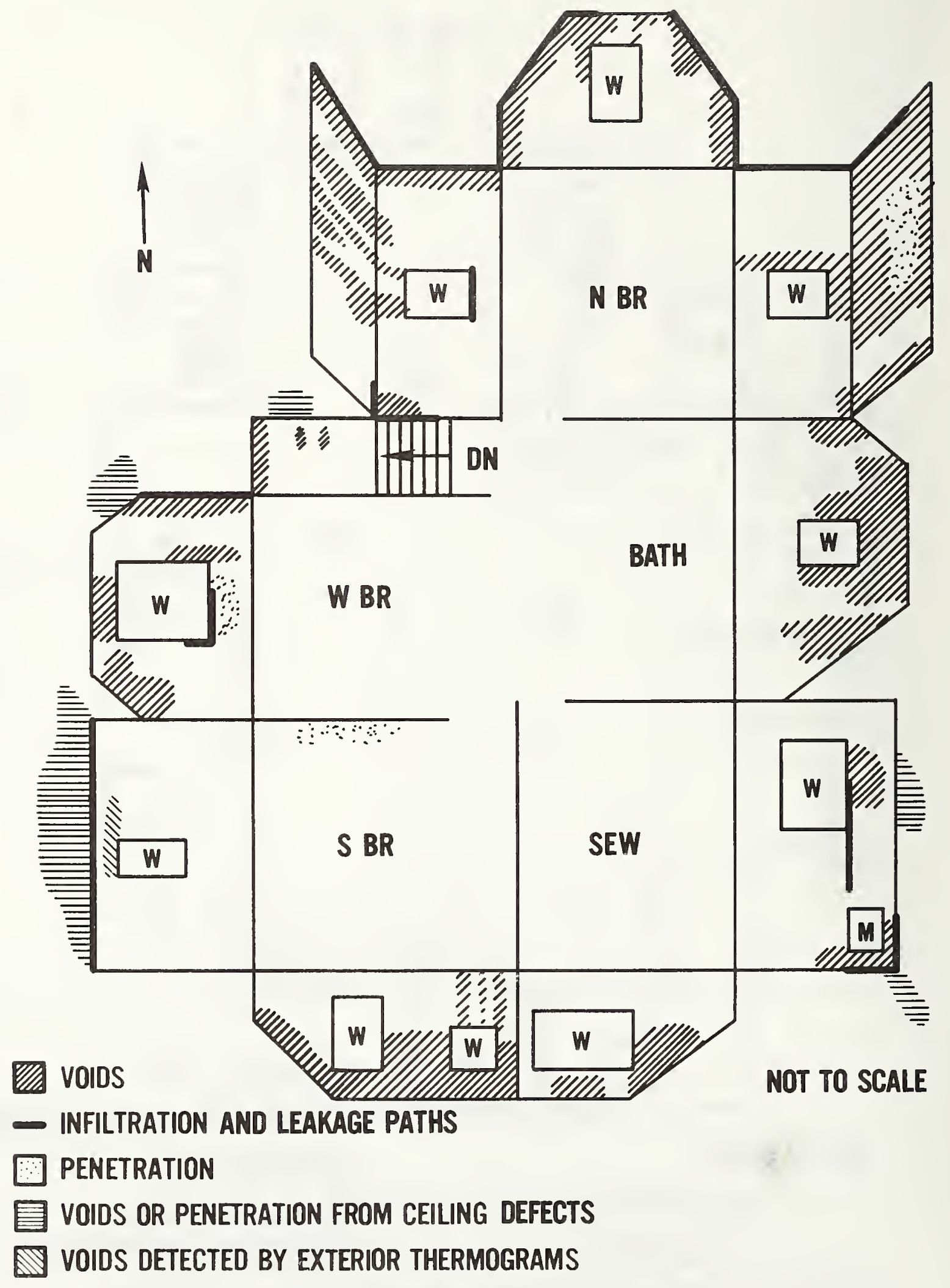

Figure VIb. Thermal deficiencies observed on the second floor in Minneapolis-St Paul house 非 


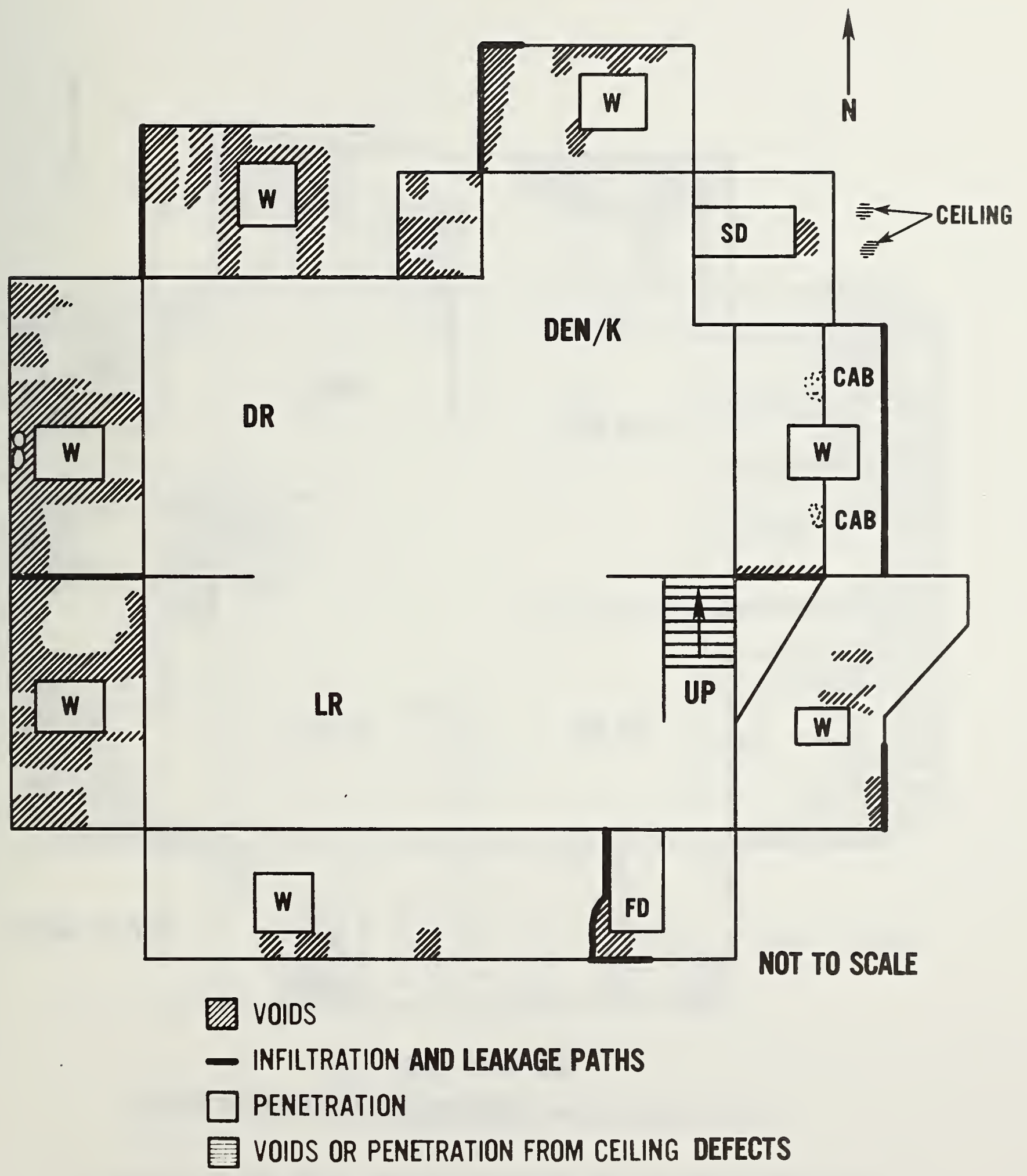

Figure VIIa. Thermal deficiencies observed on the first floor in Minneapolis-St. Paul house \#3 


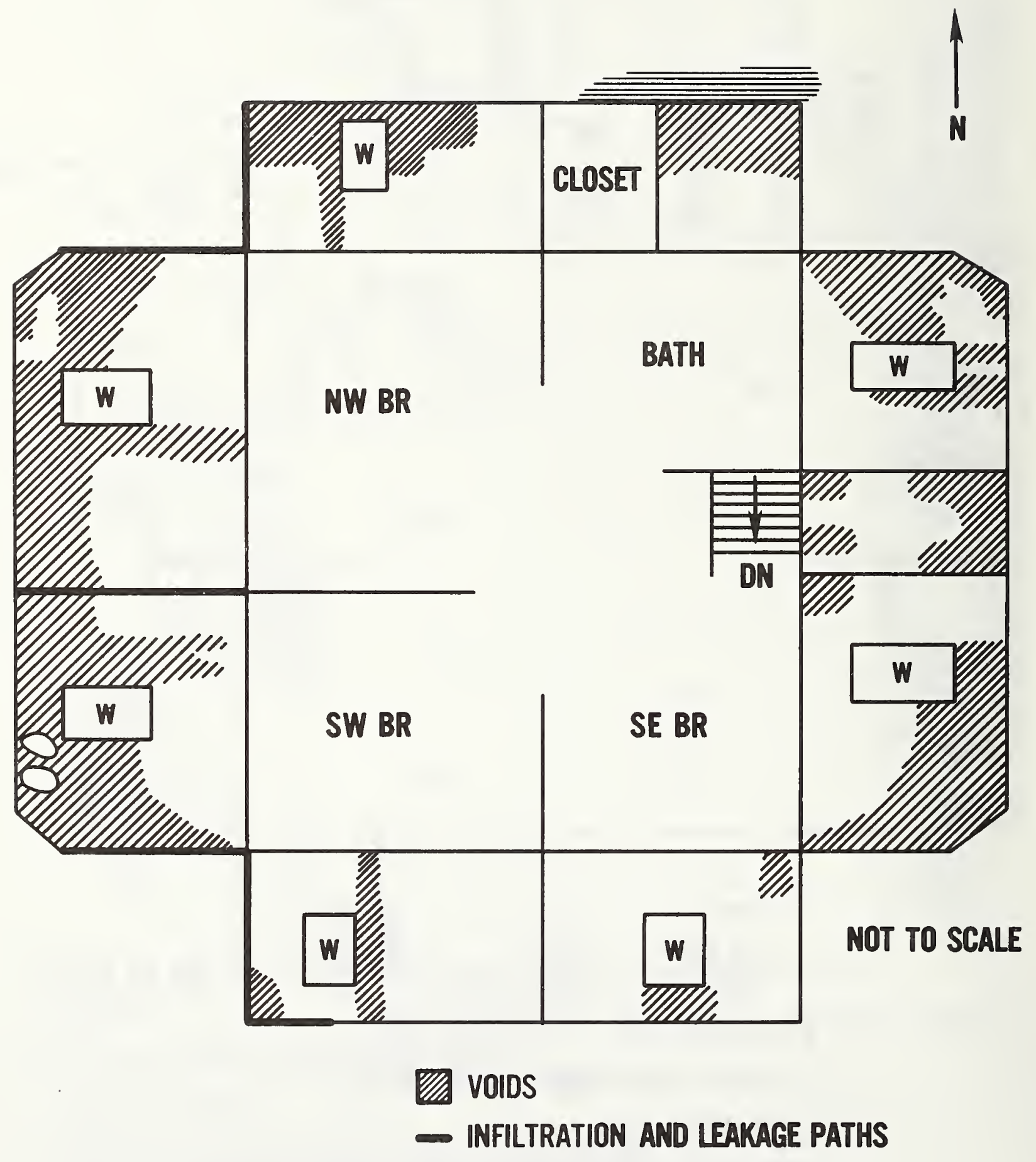

Figure VIIb. Thermal deficiencies observed on the second floor in Minneapolis-St. Paul house 非3

$$
\mathrm{A}-80
$$




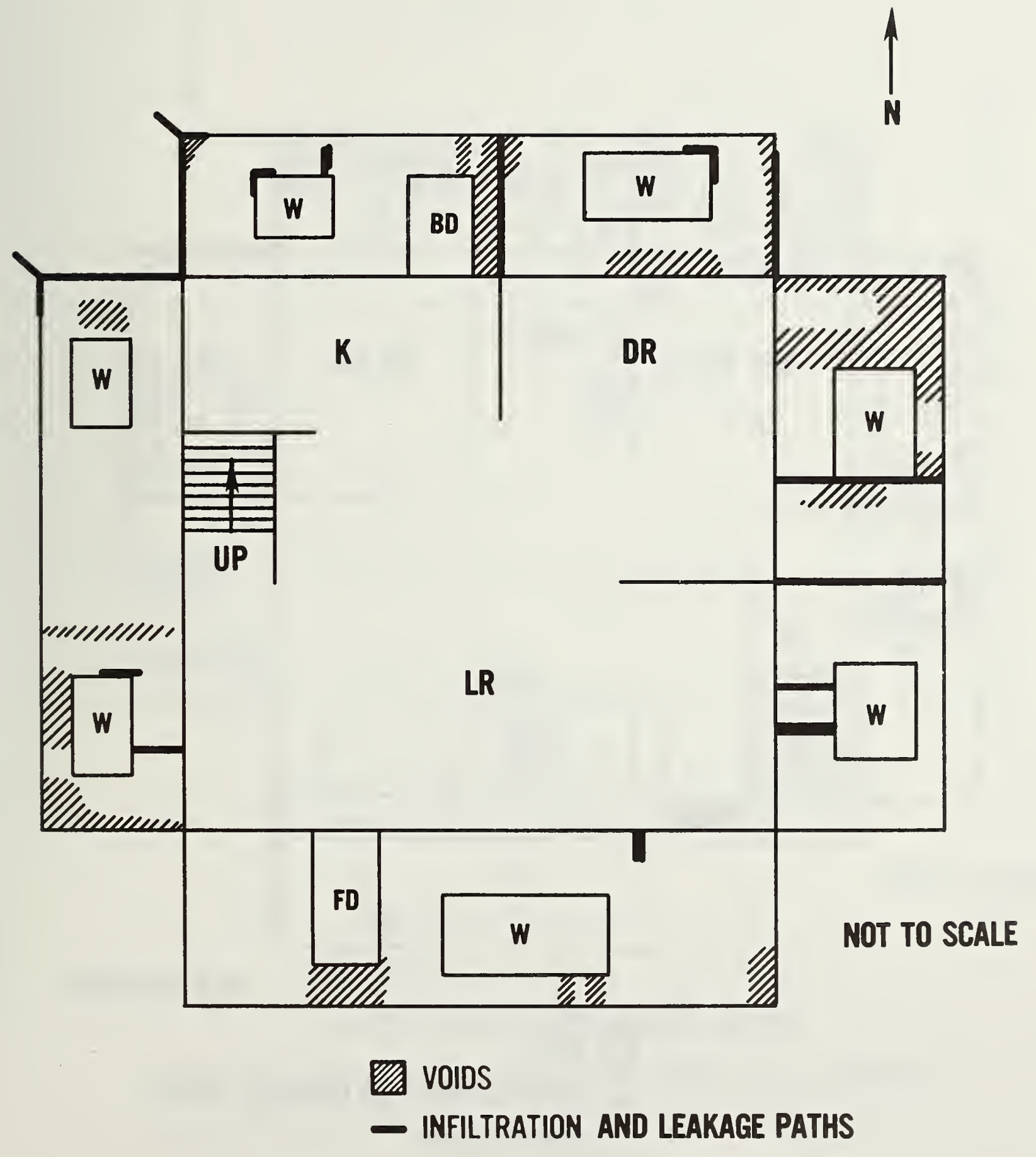

Figure VIIIa. Thermal deficiencies observed on the first floor In Minneapolis-St. Paul house 非

$$
\text { A-81 }
$$




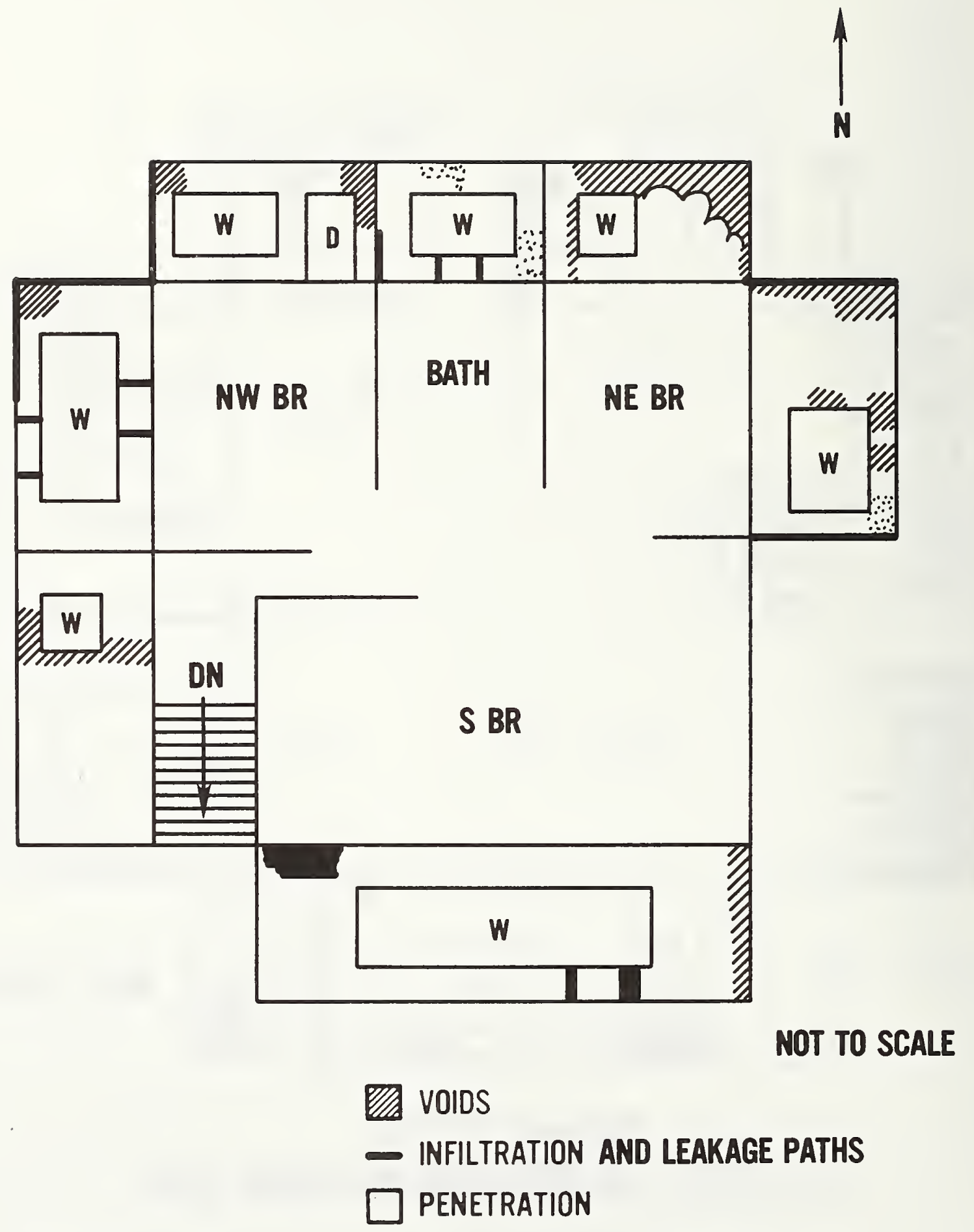

Figure VIIIb. Thermal deficiencies observed on the second floor in Minneapolis-St. Paul house $\#_{4}$

$$
\text { A-82 }
$$




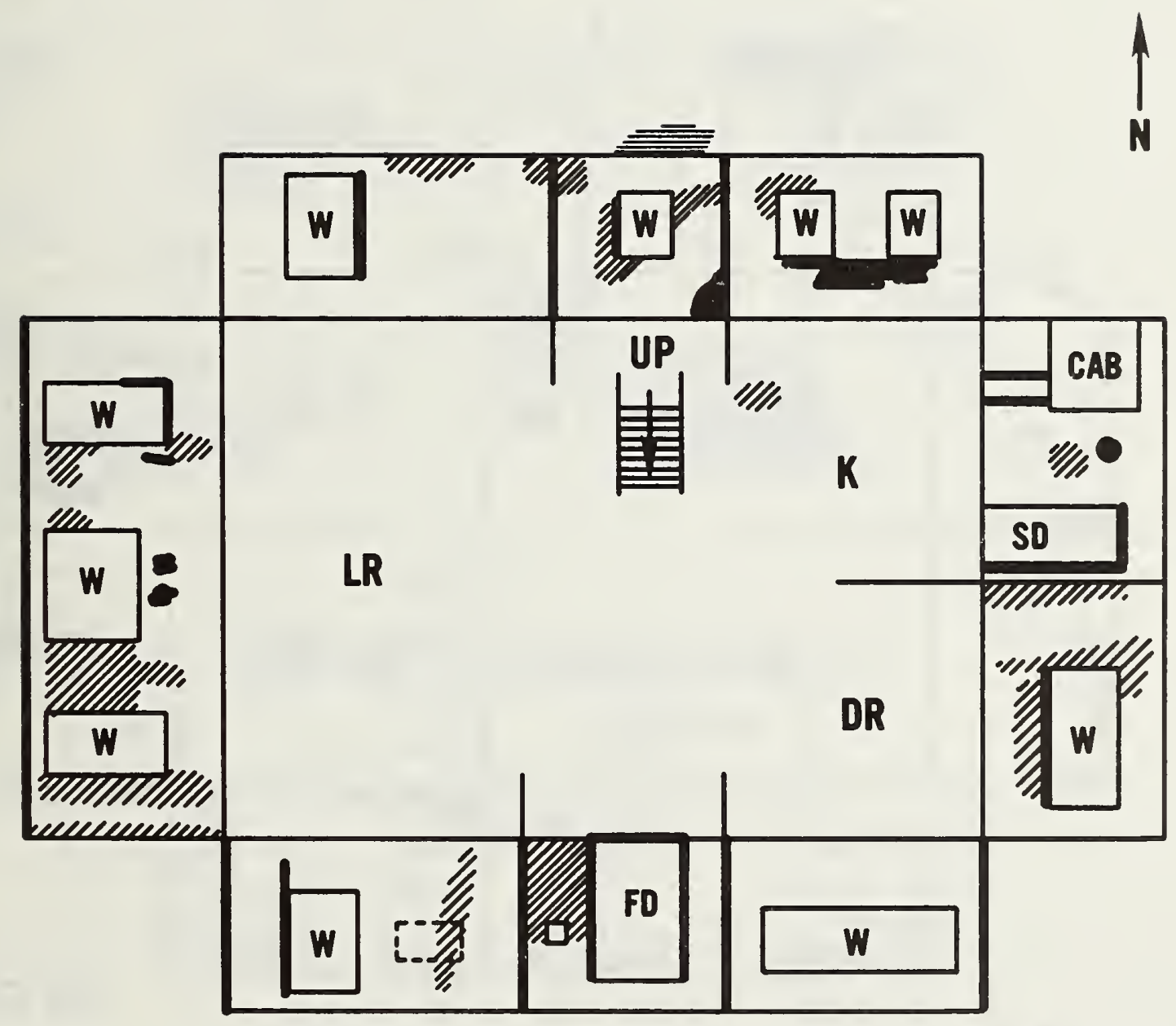

NOT TO SCALE

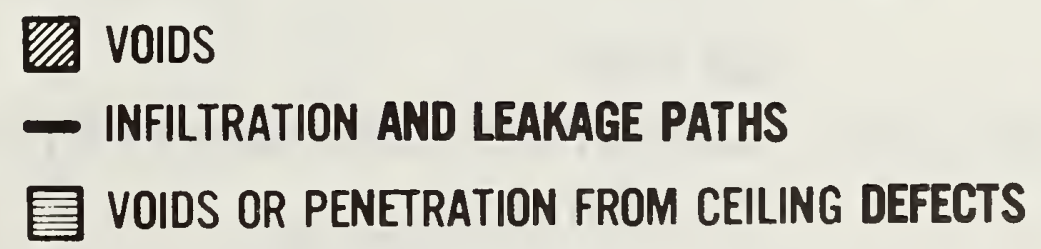

Figure IXa. Thermal deficiencies observed on the first floor in Portland house 1 


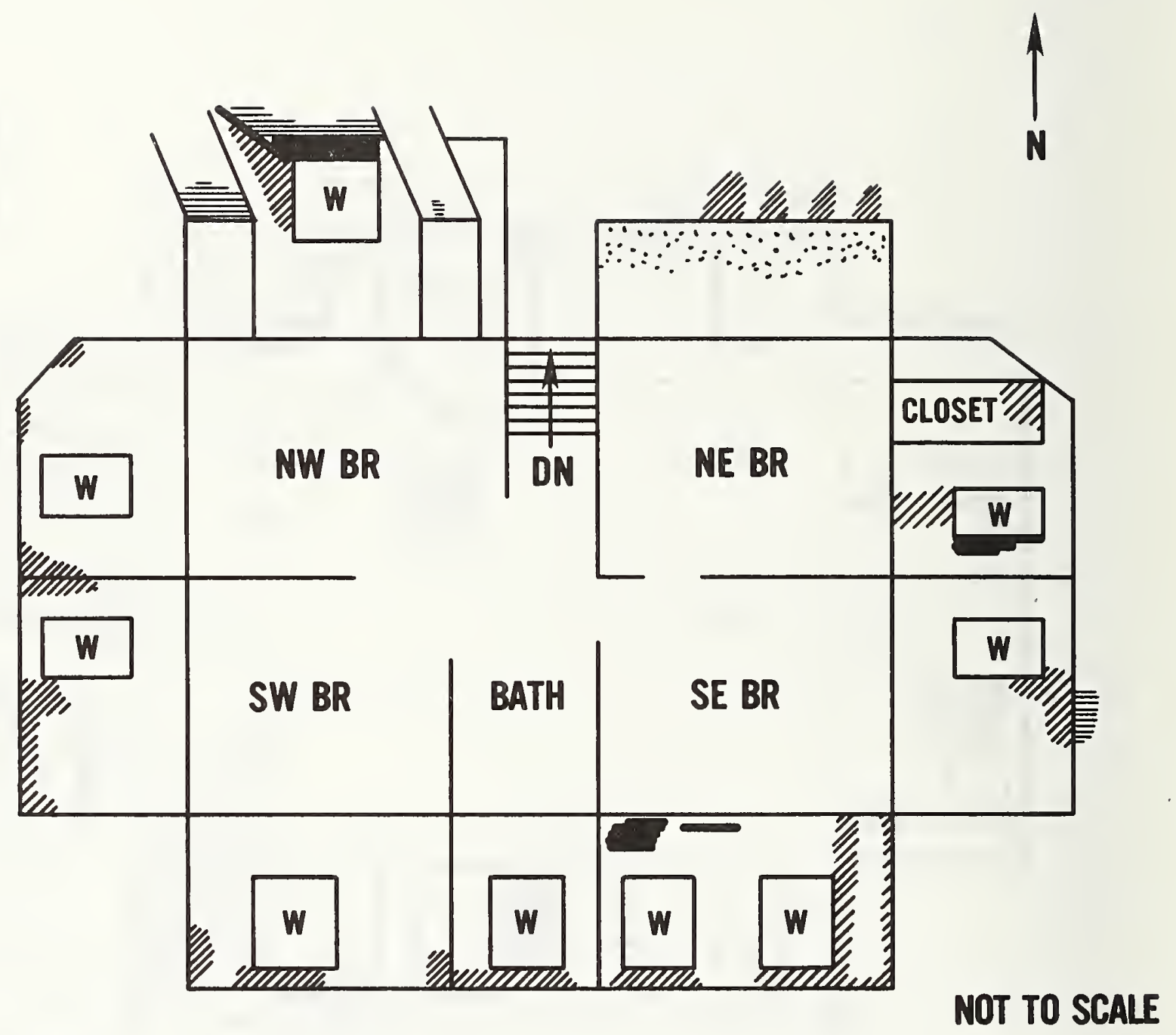

EV VOIDS

- INFILTRATION AND LEAKAGE PATHS

$\square$ PENETRATION

VOIDS OR PENETRATION FROM CEILING DEFECTS

Figure IXb. The rmal deficiencies observed on the second floor in Portland house 非

$$
A-84
$$



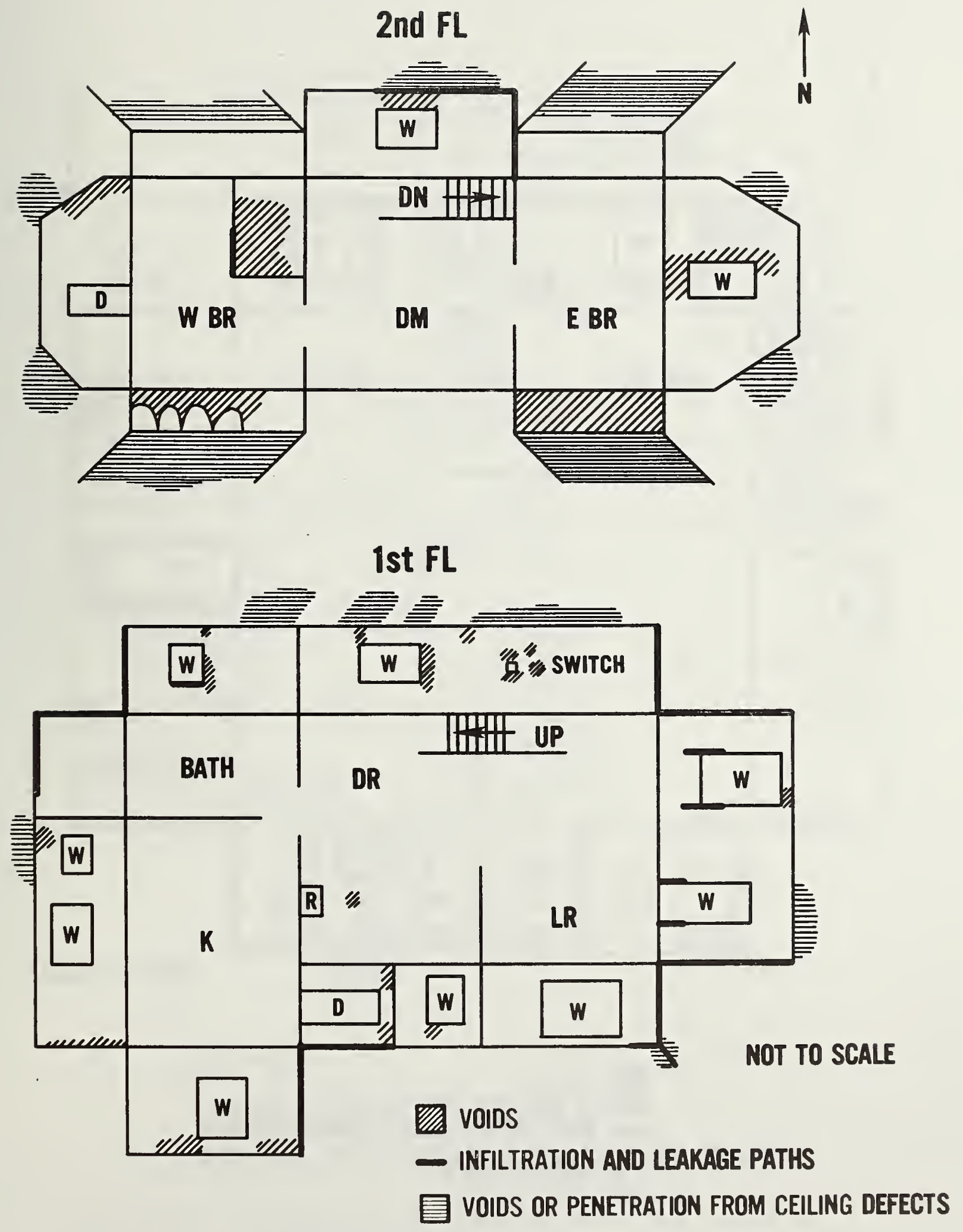

Figure $X$. Thermal deficiencies observed in Portland house \#2 

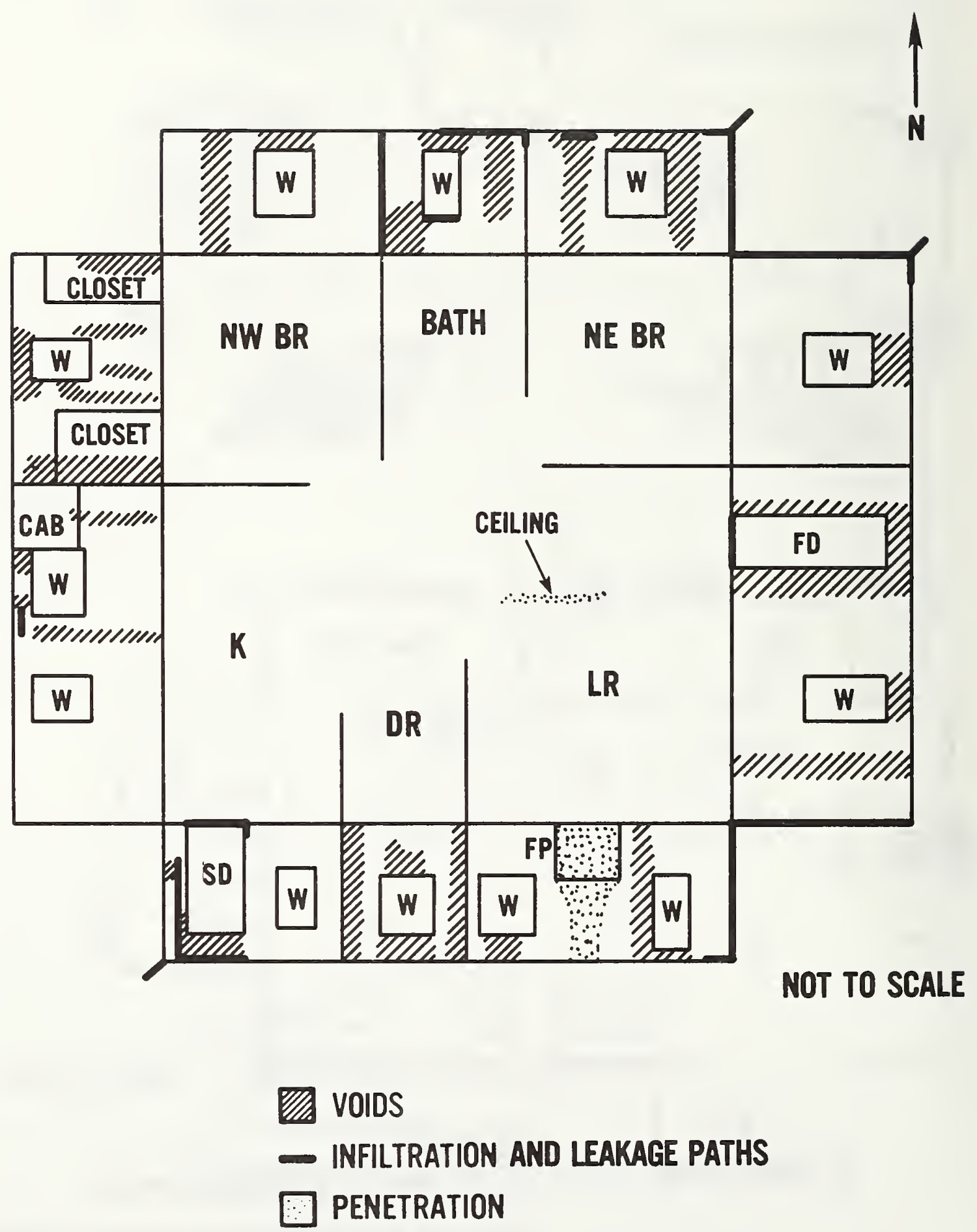

Figure XI. Thermal deficiencies observed in Portland house \#3 A-86 

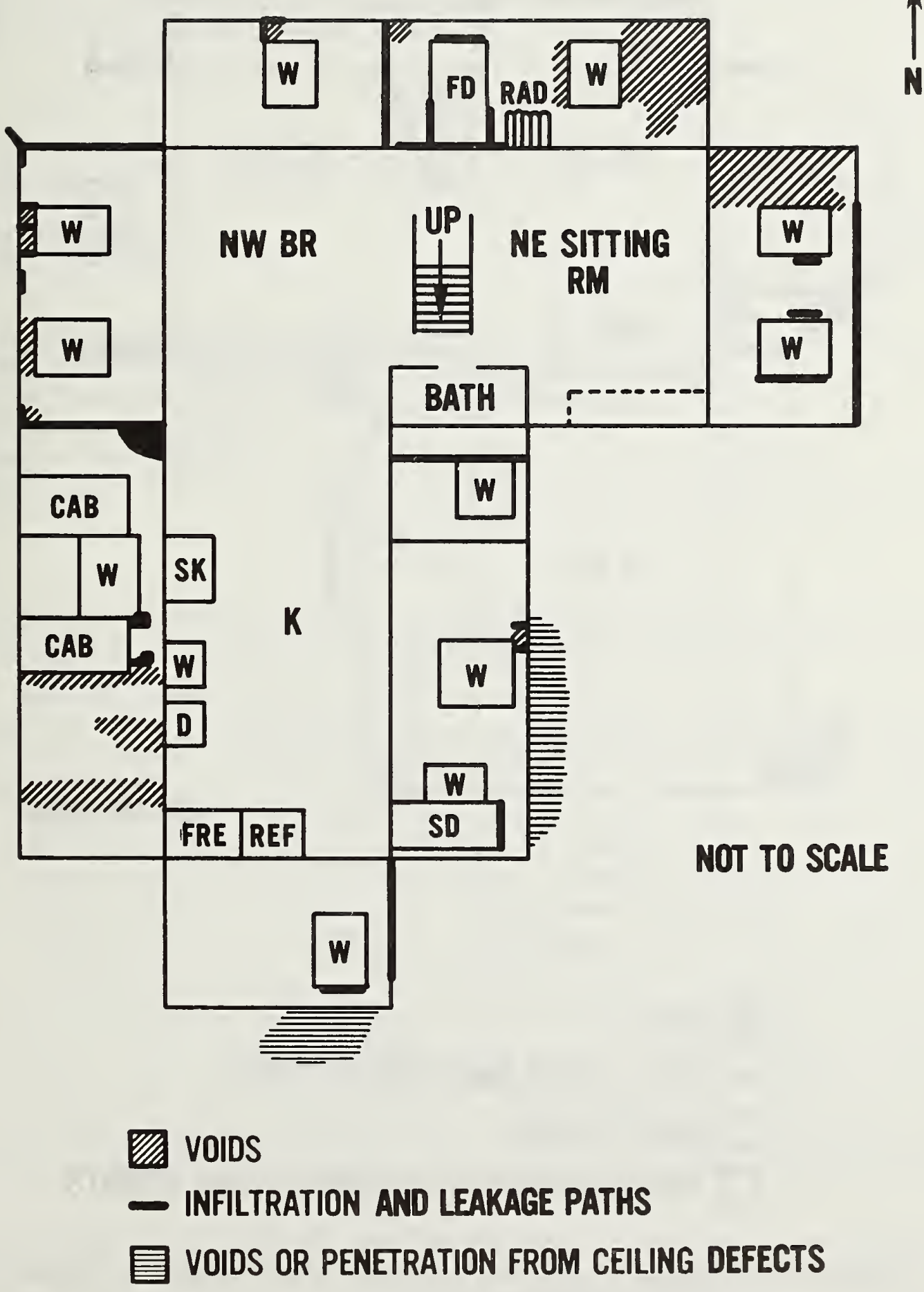

Figure XILa. Thermal deficiencies observed on the first floor in Portland house $\$ 4$ 


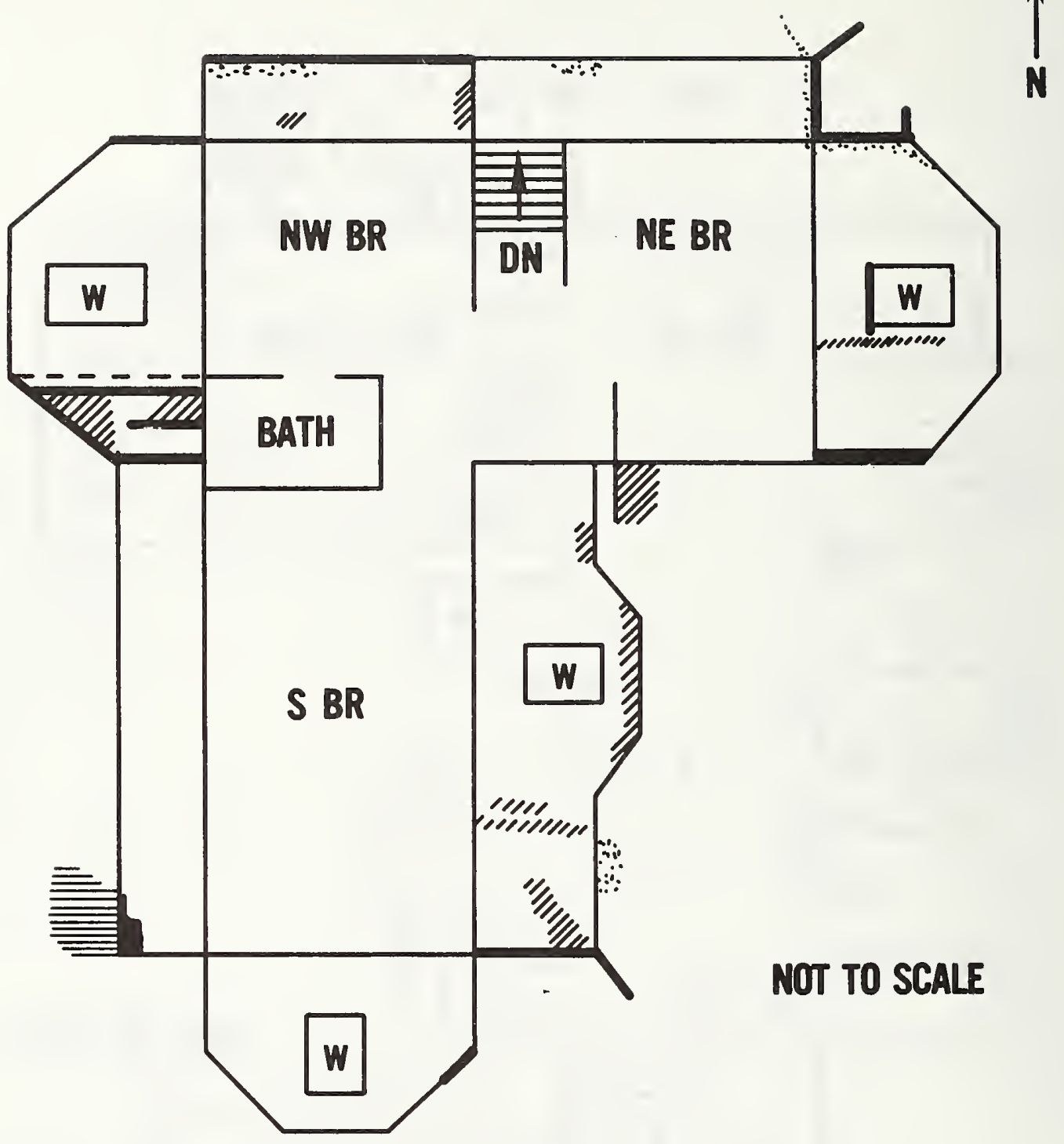

VOIDS

- INFILTRATION AND LEAKAGE PATHS

$\square$ PENETRATION

曷 VOIDS OR PENETRATION FROM CEILING DEFECTS

Figure XIIb. Thermal deficiencies observed on the second floor in Portland house \#4

$$
\text { A-88 }
$$


U.S. DEPT. OF COMM

BIBLIOGRAPHIC DATA

SHEET (See instructions)

4. TITLE AND SUBTITLE

4. TITLE AND SUBTITLE
QUALITY OF INSPECTIONS UTILIZING INFRARED TECHNOLOGY ON

WEATHERIZATION RETROFIT INSTALLATIONS
1. PUBLICATION OR REPORT NO.

NBSIR $82-2510$
2. Performing Organ. Report No. 3. Publication Date

November 1982

WEATHERIZATION RETROFIT INSTALTATIONS

5. AUTHOR(S)

Yui-May L. Chang, Richard A. Grot

6. PERFORMING ORGANIZATION (If joint or other than NBS, see instructions)

MATIONAL BUREAU OF STANDARDS

DEPARTMENT OF COMMERCE

WASHINGTON, D.C. 20234

9. SPONSORING ORGANIZATION NAME AND COMPLETE ADDRESS (Street, City, State, ZIP)

Building Energy Sciences Branch, Building Systems Division

Office of Building Energy Research and Development

U.S. Department of Energy

Washington, D.C. 20585

\section{SUPPLEMENTARY NOTES}

Document describes a computer program; SF-185, FIPS Software Summary, is attached.

11. ABSTRACT (A 200-word or less factual summary of most significant information. If document includes a significant
bibliography or literature survey, mention it here)

A comparative evaluation of various portable infrared sensing systems used for detecting heat loss anomalies within building envelopes was performed. This is the second of a two-stage applied research program sponsored by the Department of Energy to assess the application and reliability of using infrared technology. Twelve single-family residences in three cities from the Weatherization Program of the Community Services Administration were employed as field samples. The results of infrared surveys carried out by thermographic surveying firms and those by the National Bureau of Standards were analyzed and compared in the categories of: completeness of scanning, identification of defects, weather condition of inspection, and method of equipment operation. The thermograms of uninsulated areas, sketches of observed thermal deficiencies, and total areas of defects for each dwelling are presented. Through the comparison, the degree of completeness of inspecting the residences thoroughly was evaluated to be the most important factor for defect identification. The results of thermographic inspection of the homes showed that serious thermal anomalies still existed in most of these 'weatherized' residences, with a majority exhibiting between 5 percent and 15 percent of the wall areas uninsulated, or defective. The total uninsulated areas observed by each surveyor was found to be affected by the quality of thermograms submitted.

12. KEY WORDS (Six to twelve entries; alphabetical order: capitalize only proper names; and separate key words by semicolons) Building heat losses; comparison of inspections; infrared scanning systems; insulation voids; interpretation of thermograms; thermal deficiencies; thermographic inspections; weatherization retrofits.

13. AVAILABILITY

I-, Unlimited

For Official Distribution. Do Not Release to NTIS Order From Superintendent of Documents, U.S. Government Printing Office, Washington, D.C.
20402 .

X] Order From National Technical Information Service (NTIS), Springfield, VA. 22161

14. NO. OF PRINTED PAGES

109

15. Price

$\$ 12.00$ 


